\title{
Characterizing Variability in Oil Sands Upgrading Greenhouse Gas Emissions Intensity
}

\author{
Diana M. Pacheco, ${ }^{\dagger}$ Joule A. Bergerson,,$^{\ddagger}$ Anton Alvarez-Majmutov," Jinwen \\ Chen," and Heather L. MacLean ${ }^{*, t, \S}$
}

${ }^{\dagger}$ Department of Civil \& Mineral Engineering, University of Toronto, Toronto, ON, Canada M5S $1 \mathrm{~A} 4$

${ }^{\ddagger}$ Department of Chemical and Petroleum Engineering, Centre for Environmental Engineering Research and Education, Schulich School of Engineering University of Calgary, Calgary, AB, Canada T2N 1N4

"Natural Resources Canada, CanmetENERGY, Devon, AB, Canada T9G 1A8

$\S$ Department of Chemical Engineering and Applied Chemistry, School of Public Policy and Governance, University of Toronto, Toronto, ON, Canada M5S 1A4 


\section{Outline of Information Provided}

Introduction: Current Commercial Upgrading Operations in Canada (as of end of 2018)

Methods: Bitumen Upgrading Process Modeled in OSTUM 2.0 ..........................S5

Methods: Upgrading Technologies Modeled in OSTUM 2.0 …............................S9

Methods: Data and Methodology for the Modeling of OSTUM 2.0's Process Units S16

Methods: Modeling of OSTUM 2.0's DC-Based Multi-Product Upgrading Scheme S22

Methods: Modeling of OSTUM 2.0's HC-based Multi-Product Upgrading Scheme S25

Methods: Estimation of Product Properties in All Modules. S26

Methods: Estimation of a Blend's Volumetric Shrinkage, Density, Specific Gravity and API Gravity S28

Methods: Delayed Coking Based Upgrading Base Scenario Input Parameters and Assumptions

Methods: Hydroconversion Based Upgrading Base Scenario Input Parameters and Assumptions

Methods: Combined Hydroconversion and Fluid Coking Based Upgrading Base

Scenario Input Parameters and Assumptions

Methods: Main Quality Properties of Commercial SCO Blends Used to Guide OSTUM 2.0's Base Scenarios

Methods: Description of Low and High Scenarios

Methods: Delayed Coking Based Upgrading Low and High Scenarios Input

Parameters and Assumptions

Methods: Hydroconversion Based Upgrading Low and High Scenarios Input Parameters and Assumptions 
Methods: Combined Hydroconversion and Fluid Coking Based Upgrading Low and High Scenarios Input Parameters and Assumptions

Methods: Sensitivity Analysis for Delayed Coking Based Upgrading ................. S45

Methods: Sensitivity Analysis for Hydroconversion Based Upgrading ............... S46

Methods: Sensitivity Analysis for Combined Hydroconversion and Fluid Coking Based

Methods: Procedure to Fill in Gaps of Missing AER ST39 Data ........................ S48

Results: Detailed Results for the Base Scenarios of All Upgrading Technologies Evaluated

Results: Detailed Results for Hydroconversion Based Upgrading Base Scenario 2

Results: Base and Range of GHG Intensities of Hydroconversion Based Upgrading Base Scenario 2

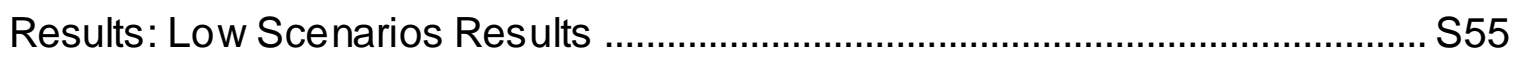

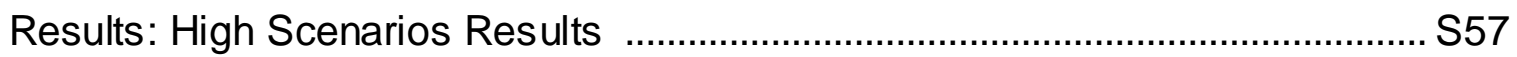

Results: GHG Intensities Allocated to DC and HC's SCO Products Using Different Allocation Methods

Results: Sensitivity Analysis

Results: Correlation of SCO Blends' H/C Atomic Ratio with Upgrading GHG Intensities.

Results: Preliminary Well-to-Wheel GHG Intensities of Oil Sands-Derived Fuel Production Pathways Involving Evaluated Upgrading Technologies. .$S 65$

Results: Comparison of GHG Intensities of Producing ULSD from Diluted Bitumen Feedstocks: Upgrader (OSTUM 2.0) and Refinery (PRELIM v1.2.1) Models

Results: Comparison of OSTUM 2.0's HC Results with Shell's Scotford Energy Use Data

Results: Comparison of OSTUM 2.0's DC Results with Suncor's Energy Use Data S70

Results: Comparison of OSTUM 2.0 Results with Syncrude's Energy Use Data

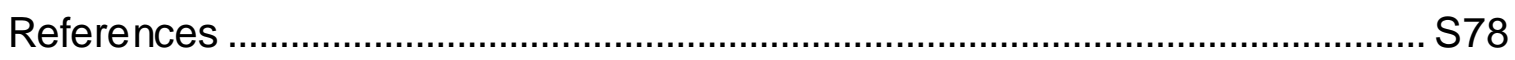




\section{Introduction: Current Commercial Upgrading Operations in Canada (as of end of 2018)}

Table S1 presents the list of current (end of 2018) upgrading projects operating in Canada, their technologies, design capacities, and synthetic crude oil (SCO) production volumes.

Table S1. Currently operating Canadian upgraders: technologies, design capacity, and synthetic crude oil production.

\begin{tabular}{|c|c|c|c|c|}
\hline Company & Project Name & Province & $\begin{array}{l}\text { Upgrading } \\
\text { Technology }\end{array}$ & $\begin{array}{c}\text { SCO Capacity } \\
\text { (bpd) }{ }^{1}\end{array}$ \\
\hline Suncor & $\begin{array}{l}\text { Base and } \\
\text { Millenium }\end{array}$ & Alberta & Delayed Coking & 357,000 \\
\hline Syncrude & Mildred Lake & Alberta & $\begin{array}{l}\text { LC-Fining } \\
\text { Ebullated-Bed } \\
\text { Hydrocracking + } \\
\text { Fluid Coking }\end{array}$ & 350,000 \\
\hline Shell & $\begin{array}{l}\text { Scotford } \\
\text { Upgrader and } \\
\text { Refinery }\end{array}$ & Alberta & $\begin{array}{c}\text { LC-Fining } \\
\text { Ebullated-Bed } \\
\text { Hydrocracking }\end{array}$ & 255,000 \\
\hline $\begin{array}{l}\text { Canadian } \\
\text { Natural } \\
\text { Resources Ltd. }\end{array}$ & Horizon & Alberta & Delayed Coking & 240,000 \\
\hline $\begin{array}{l}\text { North West } \\
\text { Redwater } \\
\text { Partnership }\end{array}$ & $\begin{array}{l}\text { Sturgeon } \\
\text { Upgrader and } \\
\text { Refinery }\end{array}$ & Alberta & $\begin{array}{c}\text { LC-Fining } \\
\text { Ebullated-Bed } \\
\text { Hydrocracking }\end{array}$ & 50,000 \\
\hline Husky & Lloydminster & Saskatchewan & $\begin{array}{c}\text { H-Oil Ebullated } \\
\text { Bed- } \\
\text { Hydrocracker + } \\
\text { Delayed Coking }\end{array}$ & 75,000 \\
\hline
\end{tabular}




\section{Methods: Bitumen Upgrading Process Modeled in OSTUM 2.0}

The first stage in the process of upgrading diluted bitumen (dilbit) into synthetic crude oil (SCO) consists of separation/fractionation processes. The diluent recovery unit (DRU) and vacuum distillation unit (VDU) separate the diluent, atmospheric topped bitumen (ATB), sour distillates, and vacuum residue or vacuum topped bitumen (VTB) present in dilbit. The diluent is recycled back to bitumen production. Sour distillates are sent to secondary upgrading. In the case of current (end of 2018) commercial upgrading operations based on delayed coking (DC) and hydroconversion ( $\mathrm{HC})$, a fraction of the sour distillates from the VDU are blended with cracked, hydrocracked, and/or hydrotreated products to produce medium/heavy sour SCO blends. VTB is delivered to the next upgrading stage -primary upgrading or conversion- where it is processed to increase its hydrogen to carbon $(\mathrm{H} / \mathrm{C})$ atomic ratio using either carbon rejection technologies (e.g., DC), hydrogen addition technologies (e.g., HC), or a combination of both (e.g., combined hydroconversion and fluid coking based upgrading, HC/FC). DC involves breaking apart the long and heavy hydrocarbon molecules in VTB into smaller, lighter molecules using high temperatures (around $500^{\circ} \mathrm{C}$ ). ${ }^{2}$ Extra carbon is concentrated in by-product coke. $\mathrm{HC}$ is another way of breaking up the large hydrocarbon molecules in VTB and increase its $\mathrm{H} / \mathrm{C}$ ratio by adding hydrogen in the presence of a catalyst. The process takes place under high pressure (7-15 MPa) and high temperature $\left(420-450^{\circ} \mathrm{C}\right) .{ }^{3} \mathrm{HC} / \mathrm{FC}$ uses a complex combination of hydroconversion and fluid coking processes to maximize conversion. ${ }^{3}$ The third upgrading stage is secondary upgrading or hydroprocessing, where a naphtha hydrotreater, a light gas oil (LGO) 
hydrotreater, and a heavy gas oil (HGO) hydrotreater improve the quality of the crude fractions by removing impurities in the sour distillates from DRU/VDU and in the products from primary upgrading. Light sweet SCO blends are produced by blending hydrotreated products. One of the two current commercial DC operations (Suncor Energy) produces ultra low sulfur diesel (ULSD) in addition to a number of heavy sour and light sweet SCO blends. Sour gases from primary and secondary upgrading are processed in the amine fuel gas treatment and amine regeneration units (AT/AR), and sulfur from acid gases (hydrogen sulfide mainly, $\mathrm{H}_{2} \mathrm{~S}$ ) is recovered in a sulfur recovery and tail gas treatment unit (SRU). OSTUM 2.0's upgrader consumes a variety of fuels, like off-site-produced natural gas and by-products fuel gas and/or coke. Steam is produced on-site either in boilers or in a cogeneration plant that generates both steam and electricity. Electricity can also be imported from the grid. Hydrogen requirements are met on-site using a steam methane reformer (SMR) of natural gas. Scheme S1 presents a simplified process flow diagram of OSTUM 2.0's upgrading process. 


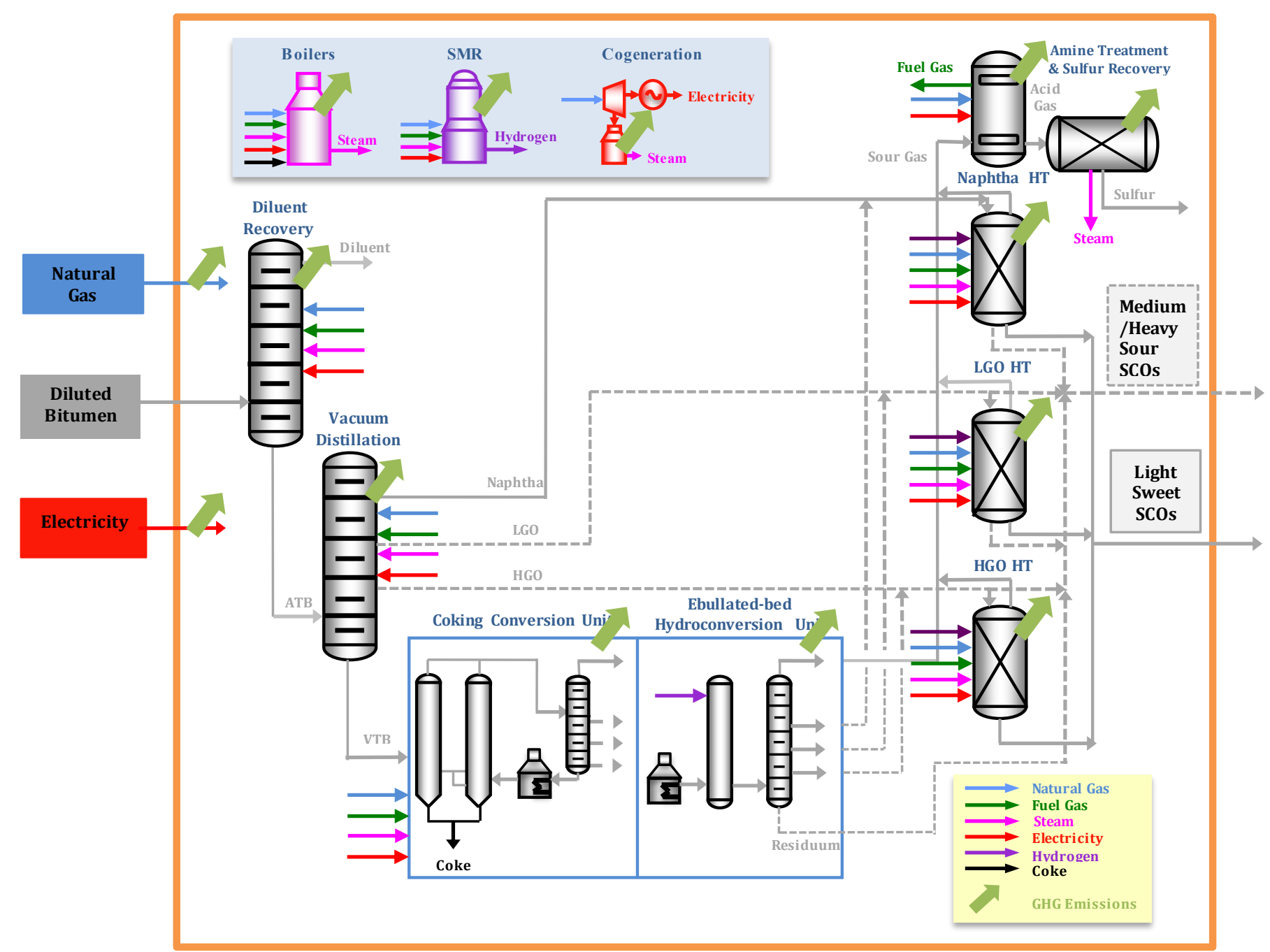


Scheme S1. Flowchart showing OSTUM 2.0's upgrading process units, utilities, material, and energy flows included within the study's boundary, including the simulation of synthetic crude oil products with different product properties.

Notes: The boundary is denoted by the orange rectangle. The primary upgrading units (enclosed by blue rectangles) are a coking unit, a hydroconversion unit, or a combination of both. Natural gas and electricity from the grid are produced outside the study's boundary but emissions associated with these are included in the modeling. Natural gas produced off-site is used as fuel in all process units and also as feedstock in the steam methane reformer. If desired, fuel gas produced as a by-product by the upgrader can be used as a substitute for natural gas in all process heaters. Steam is produced on-site in utility boilers and in the cogeneration unit. It is used in almost all process units mainly for fractionation purposes. Electricity can be obtained from the grid and/or produced on-site through cogeneration. The hydrogen consumed by the hydroprocessing units is produced on-site via steam methane reforming, the most common practice in the upgrading industry. Coke is a by-product of the delayed coker/fluid coker reactor and can be used as fuel in boilers/fluid coker. The study accounts for the GHG emissions (thick light green arrows) generated by each process unit within its boundary (direct emissions), and emissions generated off-site during the production of natural gas and electricity from the grid (indirect emissions). 


\section{Methods: Upgrading Technologies Modeled in OSTUM 2.0}

OSTUM 2.0 features the three main commercial upgrading technologies currently (end of 2018) being used by the Canadian oil sands industry: DC, HC, and $\mathrm{HC} / \mathrm{FC}$. The three technologies share similar separation and secondary upgrading processes. The key difference between the technologies lies on the primary upgrading stage: each technology employs different types of conversion units. Brief and general descriptions of each technology are shown below, as reported by the oil sands upgrading literature and as modeled in OSTUM 2.0. Actual upgrading operations by the oil sands companies applying these technologies may differ in details not available to the public (e.g., actual operating conditions, interconnection of streams).

\section{Delayed Coking Based Upgrading}

Delayed coking based upgrading (DC) is a thermal cracking, carbon rejection process in which the cracking reactions are given sufficient time (hence the name 'delayed') to proceed to completion in coke drums specially designed to accumulate coke. ${ }^{4}$ After the dilbit feed to the upgrader is processed by the DRU and VDU and separated in its diluent, sour distillates, and vacuum residue/ VTB cuts, a fraction of the sour distillates is blended with a portion of the products from the delayed coker reactor and the hydrotreaters to produce medium/heavy sour SCO blends. The rest of the sour distillates and delayed coker products are sent to hydroprocessing. All VTB is fed to the bottom of the delayed coker fractionator column, where it is heated and lighter fractions are removed. ${ }^{4}$ The bottoms of the fractionator are then heated in a furnace (temperature range: 480-515 ${ }^{\circ} \mathrm{C}$ ), where cracking reactions initiate. ${ }^{4}$ The reactions are only 
completed upon entry to one of a pair of coking drums, where reduction to coke occurs (temperature: $415-465{ }^{\circ} \mathrm{C}$, pressure: $0.1-0.4 \mathrm{MPa}$ ). ${ }^{4}$ Coke concentrates some of the impurities present in the VTB feed. Cracked products leave as overheads, and coke deposits accumulate in the drum. Two coke drums are used for continuous operation: while one is on stream, the other one is being cleaned. ${ }^{4}$ Overheads products enter the fractionator column, where coker sour gas, coker naphtha, coker LGO, and coker HGO fractions are recovered. ${ }^{5,6}$ Sour gases are processed in the AT/AR to remove $\mathrm{H}_{2} \mathrm{~S}$ (acid gas). The resulting, cleaner fuel gas is mainly used as substitute fuel for natural gas in the upgrader's process heaters. The acid gas removed from the sour gases is processed in the SRU to recover elemental sulfur. The fractions of coker naphtha, coker LGO, and coker HGO that are not blended with VDU's sour distillates to form medium/heavy sour SCOs are sent to secondary upgrading/hydroprocessing to reduce impurities. Currently there are two commercial upgrading operations using DC: Suncor's Base and Millennium and CNRL's Horizon. Suncor's plant produces heavy sour to light sweet SCO blends, while CNRL produces only light sweet SCO blends. A general process flow diagram of the delayed coking process modeled in OSTUM 2.0 is presented in Scheme S2. 


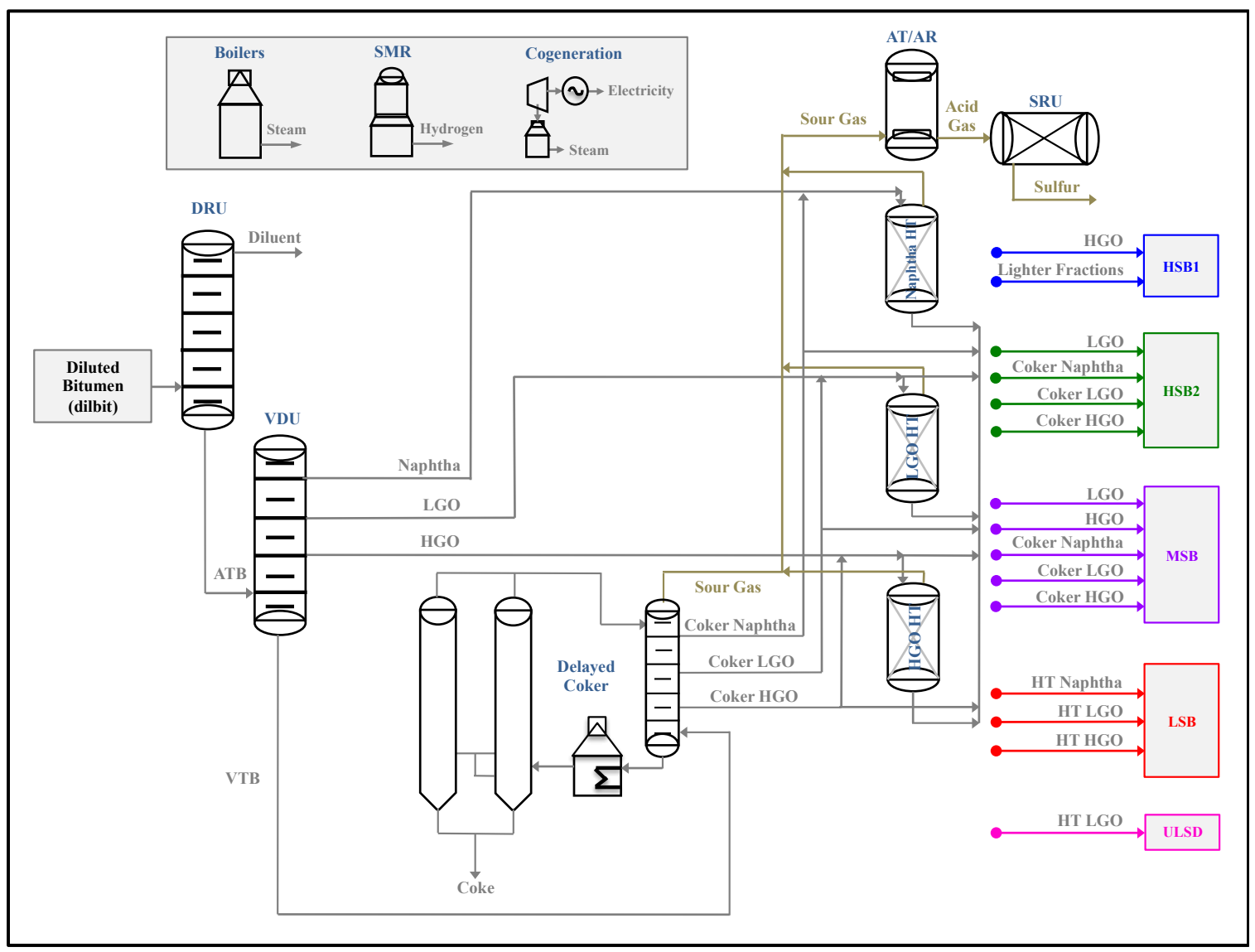

Scheme S2. Schematic flow diagram of delayed coking based upgrading as modeled in OSTUM 2.0.

Abbreviations: DRU: diluent recovery unit; ATB: atmospheric topped bitumen; VDU: vacuum distillation unit; VTB: vacuum topped bitumen; LGO: light gas oil; HGO; heavy gas oil; HT: hydrotreater/hydrotreated; AT/AR: amine treatment/regeneration units; SRU: sulfur recovery unit; SMR: steam methane reformer; HSB1: heavy sour SCO blend 1; HSB2: heavy sour SCO blend 2; MSB: medium sour SCO blend; LSB: light sweet SCO blend; ULSD: ultra-low sulfur diesel.

\section{Hydroconversion Based Upgrading}

Dilbit feed to the hydroconversion based upgrading $(\mathrm{HC})$ facility is processed by a DRU and a VDU in a similar way to DC. A fraction of the sour distillates from VDU are routed to hydrotreating, and the remaining are blended with hydrocracked and hydrotreated product streams to produce a heavy sour SCO product. All VTB is fed to an ebullated-bed hydroconverter, a multiphase and fluidized catalytic reactor that converts heavy, high boiling feedstock molecules 
into smaller, lower boiling point products through carbon bond breaking and simultaneous hydrogenation. ${ }^{7}$

The hydroconversion process uses temperatures between $420-450{ }^{\circ} \mathrm{C}$ to induce significant thermal cracking under high pressure (7-15 MPa), while the addition of hydrogen helps suppress coking reactions. ${ }^{3}$ The presence of an expanded or ebullated-bed of catalyst pellets promotes aromatics hydrogenation and hydrodesulfurization reactions. ${ }^{3}$ The fluidized catalyst prevents plugging of the bed from feeds containing fine solids and allows online catalyst replacement to avoid progressive deactivation. ${ }^{3}$ There are two similar licensed ebullated-bed hydroconversion processes: LC-Fining and H-Oil. The only differences between the two technologies are details of equipment design. ${ }^{3}$ OSTUM 2.0 simulates LC-Fining, the same technology used by Shell's Scotford upgrader/refinery and NWR's Sturgeon upgrader/refinery. Hydrogen gas and VTB feed are introduced at the bottom of the reactor and flow upward through the ebullated-bed of catalyst. Liquid and gaseous products, as well as excess hydrogen, exit the top of the reactor. ${ }^{3} \mathrm{~A}$ fraction of the liquid product is recycled to the reactor to provide the velocity required to ebullate the catalyst bed (space velocity between $\left.0.1-1.5 \mathrm{~h}^{-1}\right) .{ }^{3}$ Hydrogen gas is also recycled at approximately three or four times the hydrogen consumption rate to ensure excess hydrogen is always in the liquid state. ${ }^{3}$ The hydroconverter's liquid product is fractionated, and the majority is sent to the hydrotreating stage. A portion of the hydrocracked products, including all unconverted residuum, is blended directly into the heavy sour SCO blend. The majority of the hydrotreated products are blended to form light sweet SCO blends, while a fraction is blended into the heavy sour product. Scheme S3 provides an overview of OSTUM 2.0's HC technology. 


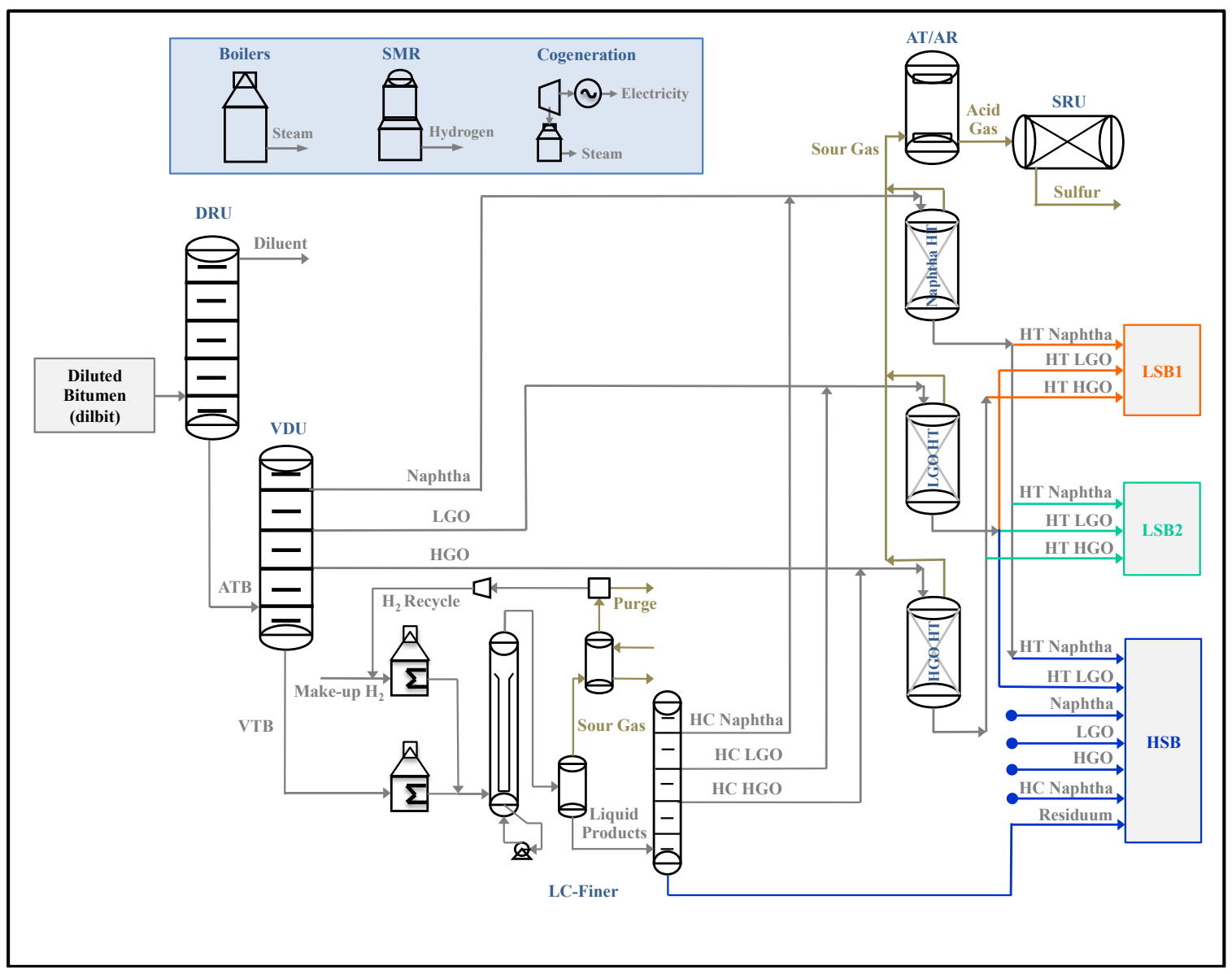

Scheme S3. Schematic flow diagram of hydroconversion based upgrading as modeled in OSTUM 2.0.

Abbreviations: DRU: diluent recovery unit; ATB: atmospheric topped bitumen; VDU: vacuum distillation unit; VTB: vacuum topped bitumen; LGO: light gas oil; HGO; heavy gas oil; HC: hydrocracked; HT: hydrotreater/hydrotreated; AT/AR: amine treatment/regeneration units; SRU: sulfur recovery unit; SMR: steam methane reformer; LSB1: light sweet SCO blend 1; LSB2: light sweet SCO blend 2; HSB: heavy sour SCO blend.

\section{Hydroconversion and Fluid Coking Based Upgrading}

The Syncrude's Mildred Lake upgrader operates the combined hydroconversion and fluid coking based upgrading ( $\mathrm{HC} / \mathrm{FC})$ technology, the most complex configuration of the current upgrading operations. ${ }^{3}$ During the dilbit's separation stage, a fraction of DRU's ATB goes to the VDU, while the remaining is fed directly to the conversion units (hydroconverter and fluid coker). VDU's VTB is also fed to both conversion units. In primary upgrading/conversion stage, HC/FC 
combines an LC-Fining hydroconverter with a fluid coker to maximize conversion. ${ }^{3}$ The LC-Finer products are sour gases, naphtha, LGO, HGO, and unconverted residuum. All unconverted residuum is fed to the fluid coker in addition to ATB and VTB. The fluid coker thermally cracks the residue in a continuous operation in which fluidized coke particles are transferred back and forth between the reactor and a burner. ${ }^{8}$ In the burner, a fraction of the coke production is burned in order to provide the heat needed for the thermal cracking process. ${ }^{8}$ The products of the fluid coker are sour gases, naphtha, gas oil, and coke. These products contain more sulfur than LC-Finer's distillates, but comparable nitrogen. ${ }^{9}$ The quality of virgin and cracked distillates is improved at the secondary upgrading stage or hydroprocessing, which includes naphtha, LGO and HGO hydrotreaters. The products from the three hydrotreaters are blended into a single light sweet SCO blend, the only product of the upgrader. Scheme S4 provides an overview of the HC/FC technology. 


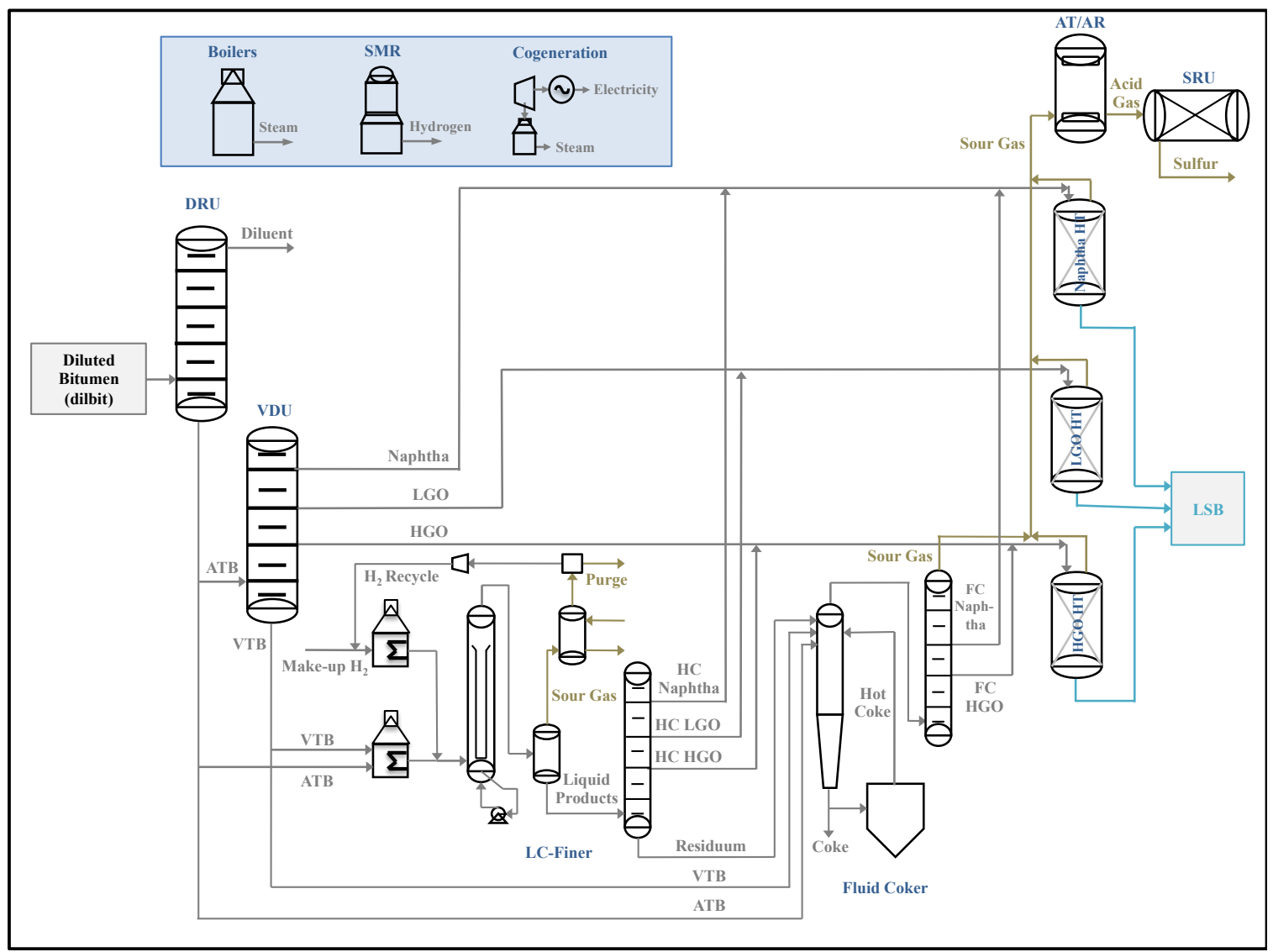

Scheme S4. Schematic flow diagram of combined hydroconversion and fluid coking based upgrading as modeled in OSTUM 2.0.

Abbreviations: DRU: diluent recovery unit; ATB: atmospheric topped bitumen; VDU: vacuum distillation unit; VTB: vacuum topped bitumen; LGO: light gas oil; HGO; heavy gas oil; HC: hydrocracked; FC: fluid coker; HT: hydrotreater; AT/AR: amine treatment/regeneration units; SRU: sulfur recovery unit; SMR: steam methane reformer; LSB: light sweet SCO blends. 


\section{Methods: Data and Methodology for the Modeling of OSTUM 2.0's Process Units}

Table S2. Data and methodology employed by OSTUM 2.0 to model the product yields, product quality, energy use, and greenhouse gas (GHG) emissions intensities of the process units included in the model.

\begin{tabular}{|c|c|c|c|c|c|c|}
\hline \multirow{2}{*}{$\begin{array}{l}\text { Upgrading } \\
\text { Stage }\end{array}$} & \multirow{2}{*}{$\begin{array}{l}\text { Upgrading } \\
\text { Technology }\end{array}$} & \multirow{2}{*}{$\begin{array}{l}\text { Process } \\
\text { Units }\end{array}$} & \multicolumn{4}{|c|}{ Key Estimations } \\
\hline & & & Yields & Product Quality & Energy Use & GHG Intensities \\
\hline \multirow{4}{*}{$\begin{array}{l}\text { Feed } \\
\text { fractionation }\end{array}$} & \multirow{4}{*}{$\begin{array}{l}\text { All } \\
\text { upgrading } \\
\text { technologies }\end{array}$} & \multirow{4}{*}{$\begin{array}{l}\text { DRU, } \\
\text { VDU }\end{array}$} & Data & & & \\
\hline & & & $\begin{array}{l}\text { - HTSD yield curve of dilbit feed } \\
\text { from Crudem onitor. }{ }^{10} \\
\text { - Cut point temperatures. } \\
\text { - Densities of crude fractions, } \\
\text { whole crude. }\end{array}$ & $\begin{array}{l}\text { - Dilbit's "mini-assay data" from } \\
\text { Crudem onitor. } \\
\text { - HTSD distillation curve of dilbit from } \\
\text { Crudem onitor. }\end{array}$ & $\begin{array}{l}\text { - Literature-bas ed energyuse } \\
\text { factors: NG as fuel, steam, } \\
\text { and electricity requirements } \\
\text { per unit volume of feed to } \\
\text { DRU, VDU. } \\
\text { - Total volume of feed to DRU, } \\
\text { VDU. }\end{array}$ & $\begin{array}{l}\text { - Energy use: total NG and FG } \\
\text { volume; electricity used. } \\
\text { - Direct EFs: NG combustion } \\
\text { EF, FG combustion EF. } \\
\text { - Indirect EFs: NG upstream EF; } \\
\text { electricity generation EF for off- } \\
\text { site generated electricity. }\end{array}$ \\
\hline & & & Methods & & & \\
\hline & & & $\begin{array}{l}\text { - Mass \% recovery at cut point } \\
\text { temperatures using } \\
\text { Crudem onitor's Interpolation } \\
\text { Calculator. } \\
\text { - Volumetric \% recovery using } \\
\text { mass \% recovery, densities of } \\
\text { crude fractions and whole crude. }\end{array}$ & $\begin{array}{l}\text { - Polynomial regression that estimates } \\
\text { quality properties (S, N, API, density, } \\
\text { and MCRT) of all DRU/NDU's crude } \\
\text { cuts as function of Tb50. } \\
\text { - } \mathrm{K}_{\mathrm{w}} \text { determined with Wats on and } \\
\text { Nelson correlation using } \mathrm{T}_{\mathrm{b}}, \mathrm{s} \text {. } \\
\text { - H of light crude fractions (diluent, } \\
\text { naphtha, LGO) predicted with } \\
\text { correlation by Goos sens. } \\
\text { - H of heavy crude fractions (HGO, } \\
\text { VR) predicted with correlation by } \\
\text { Choudharyet al. } \\
\text { - MW of crude fractions predicted with } \\
\text { correlation by Goossens. }\end{array}$ & $\begin{array}{l}\text { - NG, steam, and electricity } \\
\text { demands: product of each } \\
\text { energy use factor and total } \\
\text { volume of feed. }\end{array}$ & $\begin{array}{l}\text { - GHG emissions intensities: } \\
\text { product of a unit of energy } \\
\text { consumed and its } \\
\text { corresponding direct and } \\
\text { indirect life cycle EF. }\end{array}$ \\
\hline \multirow{4}{*}{$\begin{array}{l}\text { Primary } \\
\text { upgrading } \\
\text { (conversion } \\
\text { of VR) }\end{array}$} & \multirow[t]{4}{*}{ DC } & \multirow[t]{4}{*}{ DCU } & Data & & & \\
\hline & & & $\begin{array}{l}\text { - Reaction T. } \\
\text { - Reaction P. } \\
\text { - Reaction LSV. } \\
\text { - MCRT of feed. }\end{array}$ & - S, N, API of feed to DCU. & $\begin{array}{l}\text { - Energy use factors: NG as } \\
\text { fuel, steam, and electricity } \\
\text { requirements per unit volume } \\
\text { of feed to DCU. } \\
\text { - Total volume of feed to DCU. }\end{array}$ & $\begin{array}{l}\text { - Energy use: total NG and FG } \\
\text { volume; electricity used. } \\
\text { - DirectEFs: NG combustion } \\
\text { EF, FG combustion EF. } \\
\text { - Indirect EFs: NG upstream EF; } \\
\text { electricity generation EF for off- } \\
\text { site generated electricity. }\end{array}$ \\
\hline & & & Methods & & & \\
\hline & & & - Correlations by Volk et al. ${ }^{14}$ & $\begin{array}{l}\text { - Guidelines for S, N distribution in } \\
\text { DCU products by Gary et al. }{ }^{15} \\
\text { - H of products as reported by Gary et } \\
\text { al. }{ }^{15} \text { Yui et al. }{ }^{9} \text { and Gray. } \\
\text { - API gravity of selected DC products } \\
\text { with correlation reported by }\end{array}$ & $\begin{array}{l}\text { - NG, steam, and electricity } \\
\text { demands: product of each } \\
\text { energy use factor and total } \\
\text { volume of feed. }\end{array}$ & $\begin{array}{l}\text { - GHG emissions intensities: } \\
\text { product of a unit of energy } \\
\text { consumed and its } \\
\text { corresponding direct and } \\
\text { indirect life cycle EF. }\end{array}$ \\
\hline
\end{tabular}


Table S2. Continued.

\begin{tabular}{|c|c|c|c|c|c|c|}
\hline \multirow{2}{*}{$\begin{array}{l}\text { Upgrading } \\
\text { Stage }\end{array}$} & \multirow{2}{*}{$\begin{array}{l}\text { Upgrading } \\
\text { Technology }\end{array}$} & \multirow{2}{*}{$\begin{array}{l}\text { Process } \\
\text { Units }\end{array}$} & \multicolumn{4}{|c|}{ Key Estimations } \\
\hline & & & Yields & Product Quality & Energy Use & GHG Intensities \\
\hline \multirow{7}{*}{$\begin{array}{l}\text { Primary } \\
\text { upgrading } \\
\text { (conversion } \\
\text { of VR) }\end{array}$} & \multirow{3}{*}{$\begin{array}{l}\mathrm{HC} \text { and } \\
\mathrm{HC} / \mathrm{FC}\end{array}$} & \multirow[t]{3}{*}{$\mathrm{HCU}$} & Data & & & \\
\hline & & & $\begin{array}{l}\text { - Reaction T. } \\
\text { - LHSV or residence time. } \\
\text { - Initial mass fraction of VR in } \\
\text { feed. } \\
\text { - Kinetic parameters (e.g., pre- } \\
\text { exponential factors, activation } \\
\text { energies). } \\
\text { - S, N of feed. } \\
\text { - Level of HDS and HDN (\%) in } \\
\text { HCU. } \\
\text { Methods }\end{array}$ & $\begin{array}{l}\text { - S, N, density of feed. } \\
\text { - Reaction T. } \\
\text { - Reaction P. } \\
\text { - LHSV. } \\
\text { - Kinetic parameters (e.g., pre- } \\
\text { exponential factors, power terms for } \\
\text { P, LHSV). }\end{array}$ & $\begin{array}{l}\text { - Energy use factors: NG as } \\
\text { fuel, steam, and electricity } \\
\text { requirements per unit volume } \\
\text { or unit mass of feed to HCU. } \\
\text { - Total volume or mass of feed } \\
\text { to HCU. }\end{array}$ & $\begin{array}{l}\text { - Energy use: total NG and FG } \\
\text { volume; electricity used. } \\
\text { - Direct EFs: NG combustion } \\
\text { EF, FG combustion EF. } \\
\text { - IndirectEFs: NG upstream EF; } \\
\text { electricity generation EF for off- } \\
\text { site generated electricity. }\end{array}$ \\
\hline & & & $\begin{array}{l}- \text { - Lumped kinetic model for } \\
\text { moderate hydrocracking of } \\
\text { heavy oils by Sanchez et al. }{ }^{17} \\
\text { - Hydrogen mass balance to } \\
\text { approximate } \mathrm{H}_{2} \mathrm{~S}, \mathrm{NH}_{3} \text { and ( } \mathrm{C} 1 \text { - } \\
\text { C4) gas yields. }\end{array}$ & $\begin{array}{l}\text { - Chemical hydrogen consumption } \\
\text { with correlation by Danial-Fortain et } \\
\text { al. } \\
\text { - Approximation of H in HCU liquid } \\
\text { products (before fractionation) using } \\
\text { chemical hydrogen consumption and } \\
\text { hydrogen mass balance. } \\
\text { - Kinetic model for prediction of } \\
\text { extent of HDS, HDN in HCU liquid } \\
\text { products (before fractionation) by Yui } \\
\text { et al. } .^{19} \\
\text { - S, N, H in HCU product fractions as } \\
\text { reported by Yui et al. }{ }^{9} \text { and Alvarez- } \\
\text { Majmutov et al. } .^{20} \text { used as guidelines. } \\
\text { - API gravity of products as reported } \\
\text { by Alvarez-Majmutov et al. }{ }^{20}\end{array}$ & $\begin{array}{l}\text { - NG, steam, and electricity } \\
\text { demands: product of each } \\
\text { energy use factor and total } \\
\text { volume or mass of feed. } \\
\text { - Hydrogen demand (make-up } \\
\text { hydrogen): approximated by } \\
\text { hydrogen mass balance. }\end{array}$ & $\begin{array}{l}\text { - GHG emissions intensities: } \\
\text { product of a unit of energy } \\
\text { consumed and its } \\
\text { corresponding direct and } \\
\text { indirect life cycle EF. }\end{array}$ \\
\hline & \multirow[t]{4}{*}{$\mathrm{HC} / \mathrm{FC}$} & \multirow[t]{4}{*}{ FCU } & Data & & & \\
\hline & & & - MCRT of feed. & -S, MCRT, and API gravity of feed. & $\begin{array}{l}\text { - Energy use factors: coke, } \\
\text { steam, and electricity } \\
\text { requirem ents per unit volume } \\
\text { of feed to FCU. } \\
\text { - Total volume of feed to FCU. }\end{array}$ & $\begin{array}{l}\text { - Energy use: total coke mass } \\
\text { and electricity used by FCU. } \\
\text { - DirectEF: coke combustion } \\
\text { EF. } \\
\text { - IndirectEF: electricity } \\
\text { generation EF for off-site } \\
\text { generated electricity. }\end{array}$ \\
\hline & & & Methods & & & \\
\hline & & & $\begin{array}{l}\text { - Correlations reported by Fahim } \\
\text { et al. }{ }^{21} \text { based on data compiled } \\
\text { by Maples. }\end{array}$ & $\begin{array}{l}\text { - S and API gravity approximated } \\
\text { with correlations by Fahim et al. }{ }^{21} \\
\text { based on data compiled by Maples. }{ }^{22} \\
\text { - N, H, API gravity of products as } \\
\text { reported by Yui et al. }\end{array}$ & $\begin{array}{l}\text { - Coke, steam, and electricity } \\
\text { demands: product of each } \\
\text { energy use factor and total } \\
\text { volume of feed. }\end{array}$ & $\begin{array}{l}\text { - GHG emissions intensities: } \\
\text { product of a unit of energy } \\
\text { consumed and its } \\
\text { corresponding direct and } \\
\text { indirect life cycle EF. }\end{array}$ \\
\hline
\end{tabular}


Table S2. Continued.

\begin{tabular}{|c|c|c|c|c|c|c|}
\hline \multirow{2}{*}{$\begin{array}{l}\text { Upgrading } \\
\text { Stage }\end{array}$} & \multirow{2}{*}{$\begin{array}{l}\text { Upgrading } \\
\text { Technology }\end{array}$} & \multirow{2}{*}{$\begin{array}{l}\text { Process } \\
\text { Units }\end{array}$} & \multicolumn{4}{|c|}{ Key Estimations } \\
\hline & & & Yields & Product Quality & Energy Use & GHG Intensities \\
\hline \multirow{8}{*}{$\begin{array}{l}\text { Secondary } \\
\text { upgrading } \\
\text { (hydro- } \\
\text { processing) }\end{array}$} & \multirow{8}{*}{$\begin{array}{l}\text { All } \\
\text { upgrading } \\
\text { technologies }\end{array}$} & \multirow{4}{*}{$\begin{array}{l}\text { Naphtha } \\
\text { HT }\end{array}$} & Data & & & \\
\hline & & & $\begin{array}{l}-\mathrm{S}, \mathrm{N} \text { of feed. } \\
\text { - Extent of HDS, HDN. }\end{array}$ & $\begin{array}{l}\text { - Feed's Br number, diene number, } \\
\text { Ar, S, and N. } \\
\text { - Reaction T. } \\
\text { - Reaction P. } \\
\text { - Reaction LHSV. } \\
\text { - Kinetic parameters (e.g., pre- } \\
\text { exponential factors) }\end{array}$ & $\begin{array}{l}\text { - Energy use factors: NG, } \\
\text { steam, and electricity } \\
\text { requirements per unit volume } \\
\text { or unit mass of feed to } \\
\text { naphtha HT. } \\
\text { - Total volume or total mass of } \\
\text { feed to naphtha HT. }\end{array}$ & $\begin{array}{l}\text { - Energy use: total NG and FG } \\
\text { volume; electricity used. } \\
\text { - DirectEFs: NG combustion } \\
\text { EF, FG combustion EF. } \\
\text { - IndirectEFs: NG upstream EF; } \\
\text { electricity generation EF for off- } \\
\text { site generated electricity. }\end{array}$ \\
\hline & & & Methods & & & \\
\hline & & & $\begin{array}{l}\cdot \text { Hydrocracking reactions } \\
\text { assumed to be negligible: all } \\
\text { liquid product is hydrotreated } \\
\text { naphtha. } \\
\cdot \mathrm{H}_{2} \mathrm{~S} \text { and } \mathrm{NH}_{3} \text { yields } \\
\text { approximated by hydrogen mass } \\
\text { balance. }\end{array}$ & $\begin{array}{l}\text { - Olefins, diolefins, } \mathrm{Ar}, \mathrm{S} \text {, and } \mathrm{N} \text { : } \\
\text { kinetic model by Yui. }{ }^{23} \text { for prediction } \\
\text { of the extent of hydrogenation } \\
\text { reactions. } \\
\text { - Prediction of chemical hydrogen } \\
\text { consumption using method by } \\
\text { Edgar }^{24} \text { adding average contribution } \\
\text { of each hydroprocessing reaction. } \\
\text { - Approximation of } \mathrm{H} \text { with chemical } \\
\text { hydrogen consumption and hydrogen } \\
\text { mass balance. } \\
\text { - API gravity as reported by Yui et } \\
\text { al., }{ }^{9} \text { Alvarez-Majmutov et al. }{ }^{20}\end{array}$ & $\begin{array}{l}- \text { NG, steam, and electricity } \\
\text { demands: product of each } \\
\text { energy use factor and the total } \\
\text { volume or total mass of feed. } \\
\text { - Hydrogen demand (make-up } \\
\text { hydrogen): approximated by } \\
\text { hydrogen mass balance. }\end{array}$ & $\begin{array}{l}\text { - GHG emissions intensities: } \\
\text { product of a unit of energy } \\
\text { consumed and its } \\
\text { corresponding direct and } \\
\text { indirect life cycle EF. }\end{array}$ \\
\hline & & \multirow[t]{4}{*}{ LGO HT } & Data & & & \\
\hline & & & $\begin{array}{l}\text { - Reaction T. } \\
\text { - Reaction P. } \\
\text { - Reaction LHSV. } \\
\text { - Fraction of HGO, LGO, naphtha } \\
\text { in feed } \\
\text { - Kinetic parameters (e.g., pre- } \\
\text { exponential factors, activation } \\
\text { energies) } \\
\text { - S, N of feed. } \\
\text { - Extent of HDS, HDN. }\end{array}$ & $\begin{array}{l}\text { - Feed's S, N, Ar, and density. } \\
\text { - Reaction T. } \\
\text { - Reaction P. } \\
\text { - Reaction LHSV. } \\
\text { - Kinetic parameters (e.g., pre- } \\
\text { exponential factors, activation } \\
\text { energies). }\end{array}$ & $\begin{array}{l}\text { - Energy use factors: NG, } \\
\text { steam, and electricity } \\
\text { requirements per unit volume } \\
\text { or unit mass of feed to LGO } \\
\text { HT. } \\
\text { - Total volume or total mass of } \\
\text { feed to LGO HT. }\end{array}$ & $\begin{array}{l}\text { - Energy use: total NG and FG } \\
\text { volume; electricity used by LGO } \\
\text { HT. } \\
\text { - DirectEFs: NG combustion } \\
\text { EF, FG combustion EF. } \\
\text { - IndirectEFs: NG upstream EF; } \\
\text { electricity generation EF for off- } \\
\text { site generated electricity. }\end{array}$ \\
\hline & & & Methods & & & \\
\hline & & & $\begin{array}{l}\text { - Yields of hydrotreated naphtha } \\
\text { and LGO with kinetic model for } \\
\text { mild hydrocracking of bitumen- } \\
\text { derived coker and hydrocracker } \\
\text { heavy gas oils by Yui et al. }{ }^{19} \\
\text { - } \mathrm{H}_{2} \mathrm{~S} \text { and } \mathrm{NH}_{3} \text { yields } \\
\text { approximated by hydrogen mass } \\
\text { balance. }\end{array}$ & $\begin{array}{l}\text { - HDS, HDN, S, N: kinetic model for } \\
\text { mild hydrocracking of bitumen- } \\
\text { derived coker and hydrocracker } \\
\text { heavy gas oils by Yui et al. }{ }^{19} \\
\text { - Ar: kinetic model of aromatics } \\
\text { hydrogenation of bitumen-derived gas } \\
\text { oils by Yui et al. }{ }^{25} \\
\text { - Chemical hydrogen consumption: } \\
\text { method by Edgar. } \\
\text { - H: chemical hydrogen consumption } \\
\text { and hydrogen mass balance. } \\
\text { - Density, specific gravity, API with } \\
\text { correlation by Yui et al. }{ }^{26}\end{array}$ & $\begin{array}{l}\text { - NG, steam, and electricity } \\
\text { demands: product of each } \\
\text { energy use factor and the total } \\
\text { volume or total mass of feed. } \\
\text { - Hydrogen demand (make-up } \\
\text { hydrogen): approximated by } \\
\text { hydrogen mass balance. }\end{array}$ & $\begin{array}{l}\text { - GHG emissions intensities: } \\
\text { product of a unit of energy } \\
\text { consumed and its } \\
\text { corresponding direct and } \\
\text { indirect life cycle EF. }\end{array}$ \\
\hline
\end{tabular}


Table S2. Continued.

\begin{tabular}{|c|c|c|c|c|c|c|}
\hline \multirow{2}{*}{$\begin{array}{l}\text { Upgrading } \\
\text { Stage }\end{array}$} & \multirow{2}{*}{$\begin{array}{l}\text { Upgrading } \\
\text { Technology }\end{array}$} & \multirow{2}{*}{$\begin{array}{l}\text { Process } \\
\text { Units }\end{array}$} & \multicolumn{4}{|c|}{ Key Estimations } \\
\hline & & & Yields & Product Quality & Energy Use & GHG Intensities \\
\hline \multirow{4}{*}{$\begin{array}{l}\text { Secondary } \\
\text { upgrading } \\
\text { (hydro- } \\
\text { processing) }\end{array}$} & \multirow{10}{*}{$\begin{array}{l}\text { All } \\
\text { upgrading } \\
\text { technologies }\end{array}$} & \multirow[t]{4}{*}{ HGO HT } & Data & & & \\
\hline & & & $\begin{array}{l}- \text { Reaction T. } \\
\text { - Reaction P. } \\
\text { - Reaction LHSV. } \\
\text { - Fraction of HGO, LGO, naphtha } \\
\text { in feed. } \\
\text { - Kinetic parameters (e.g., pre- } \\
\text { exponential factors). } \\
\text { - S, N of feed. } \\
\text { - Extent of HDS, HDN. } \\
\end{array}$ & $\begin{array}{l}\text { - Feed's S, N, Ar, and density. } \\
\text { - Reaction T. } \\
\text { - Reaction P. } \\
\text { - Reaction LHSV. } \\
\text { - Kinetic parameters (e.g., pre- } \\
\text { exponential factors). }\end{array}$ & $\begin{array}{l}\text { - Energy use factors: NG, } \\
\text { steam, and electricity } \\
\text { requirements per unit volume } \\
\text { or unit mass of feed to HGO } \\
\text { HT. } \\
\text { - Total volume or total mass of } \\
\text { feed to HGO HT. }\end{array}$ & $\begin{array}{l}\text { - Energy use: total NG and FG } \\
\text { volume; electricity used by HGO } \\
\text { HT. } \\
\text { - DirectEFs: NG combustion } \\
\text { EF, FG combustion EF. } \\
\text { - IndirectEFs: NG upstream EF; } \\
\text { electricity generation EF for off- } \\
\text { site generated electricity. }\end{array}$ \\
\hline & & & Methods & & & \\
\hline & & & $\begin{array}{l}\text { - Yields of hydrotreated naphtha, } \\
\text { LGO, and HGO fractions with } \\
\text { kinetic model for mild } \\
\text { hydrocracking of bitumen-derived } \\
\text { coker and hydrocracker heavy } \\
\text { gas oils by Yui et al. }{ }^{19} \\
\text { - } \mathrm{H}_{2} \mathrm{~S} \text { and } \mathrm{NH}_{3} \text { yields } \\
\text { approximated by hydrogen mass } \\
\text { balance. }\end{array}$ & $\begin{array}{l}\text { - HDS, HDN, S, N: kinetic model for } \\
\text { mild hydrocracking of bitumen- } \\
\text { derived coker and hydrcracker heavy } \\
\text { gas oils by Yui et al. }{ }^{19} \\
\text { - Ar: kinetic model of aromatics } \\
\text { hydrogenation of bitumen-derived } \\
\text { gas oils by Yui et al. }{ }^{25} \\
\text { - Chemical hydrogen consumption: } \\
\text { method by Edgar. } \\
\text { - H: chemical hydrogen consumption } \\
\text { and hydrogen mass balance. } \\
\text { - Density, specific gravity, API with } \\
\text { correlation by Yui et al. }{ }^{26}\end{array}$ & $\begin{array}{l}\text { - NG, steam, and electricity } \\
\text { demands: product of each } \\
\text { energy use factor and the total } \\
\text { volume or total mass of feed. } \\
\text { - Hydrogen demand (make-up } \\
\text { hydrogen): approximated by } \\
\text { hydrogen mass balance. }\end{array}$ & $\begin{array}{l}\text { - GHG emissions intensities: } \\
\text { product of a unit of energy } \\
\text { consumed and its } \\
\text { corresponding direct and } \\
\text { indirect life cycle EF. }\end{array}$ \\
\hline \multirow{6}{*}{$\begin{array}{l}\text { Environmen- } \\
\text { tal Controls }\end{array}$} & & \multirow[t]{4}{*}{ AT/AR } & Data & & & \\
\hline & & & $\begin{array}{l}- \text { Mass flow rate of sour gases } \\
\text { from DCU, FCU, HCU, naphtha } \\
\text { HT, LGO HT, HGO HT. } \\
\text { - } \mathrm{H}_{2} \mathrm{~S}, \mathrm{NH}_{3} \text { yield from HCU, } \\
\text { naphtha HT, LGO HT, HGO HT. } \\
\text { - S, N of DCU and FCU's sour } \\
\text { gases. }\end{array}$ & - No data needed. & $\begin{array}{l}\text { - Energy use factors: steam } \\
\text { and electricity requirements } \\
\text { per unit mass of feed to } \\
\text { AR/AT. } \\
\text { - Total mass of feed to AR/AT. }\end{array}$ & $\begin{array}{l}\text { - Energy use: total electricity } \\
\text { used by AR/AT. } \\
\text { - DirectEFs: none. } \\
\text { - IndirectEFs: electricity } \\
\text { generation EF for off-site } \\
\text { generated electricity }\end{array}$ \\
\hline & & & Methods & & & \\
\hline & & & $\begin{array}{l}- \text { Assumption: clean fuel gas }= \\
\text { mass flow rate of sour gases - } \\
\text { mass flow rate of } \mathrm{H}_{2} \mathrm{~S} \text { - mass flow } \\
\text { rate of } \mathrm{NH}_{3} \text {. }\end{array}$ & $\begin{array}{l}- \text { Assumption: } 100 \% \text { rem oval of } \mathrm{H}_{2} \mathrm{~S} \text {, } \\
\mathrm{NH}_{3} \text {. }\end{array}$ & $\begin{array}{l}\text { - Steam and electricity } \\
\text { demands: product of each } \\
\text { energy use factor and the total } \\
\text { mass of feed. }\end{array}$ & $\begin{array}{l}\text { - GHG emissions intensities: } \\
\text { product of a unit of energy } \\
\text { consumed and its } \\
\text { corresponding indirect life cycle } \\
\text { EF. }\end{array}$ \\
\hline & & \multirow[t]{2}{*}{ SRU } & Data & & & \\
\hline & & & $\begin{array}{l}- \text { - Amount of } \mathrm{H}_{2} \mathrm{~S} \text { removed from } \\
\text { sour gases. } \\
\text { - Typical sulfur recovery yield } \\
\text { percentage of } \mathrm{SRU} \text { and of tail gas } \\
\text { treatment. }\end{array}$ & - No data needed. & $\begin{array}{l}\text { - Energy use factors: NG and } \\
\text { electricity requirements/mass } \\
\text { of sulfur recovered. } \\
\text { - Total sulfur recovered. }\end{array}$ & $\begin{array}{l}\text { - Energy use: total NG and FG } \\
\text { volume, electricity used by } \\
\text { SRU. } \\
\text { - DirectEFs: NG combustion } \\
\text { EF, FG combustion EF. } \\
\text { - IndirectEFs: NG upstream EF; } \\
\text { electricity generation EF for off- } \\
\text { site generated electricity. }\end{array}$ \\
\hline
\end{tabular}


Table S2. Continued.

\begin{tabular}{|c|c|c|c|c|c|c|}
\hline \multirow{2}{*}{$\begin{array}{l}\text { Upgrading } \\
\text { Stage }\end{array}$} & \multirow{2}{*}{$\begin{array}{l}\text { Upgrading } \\
\text { Technology }\end{array}$} & \multirow{2}{*}{$\begin{array}{l}\text { Process } \\
\text { Units }\end{array}$} & \multicolumn{4}{|c|}{ Key Estimations } \\
\hline & & & Yields & Product Quality & Energy Use & GHG Intensities \\
\hline \multirow{2}{*}{$\begin{array}{l}\text { Environmen- } \\
\text { tal Controls }\end{array}$} & \multirow{14}{*}{$\begin{array}{l}\text { All } \\
\text { upgrading } \\
\text { technologies }\end{array}$} & \multirow[t]{2}{*}{ SRU } & Methods & & & \\
\hline & & & $\begin{array}{l}- \text { Sulfur recovered }=(\% \text { sulfur } \\
\text { recovery yield in SRU) * moles of } \\
\text { sulfur in } \mathrm{H}_{2} \mathrm{~S} ;(\% \text { sulfur recovery } \\
\text { yield in tail gases) } \\
\text { in tail gases. }{ }^{27}\end{array}$ & $\begin{array}{l}\text { - Assumption: product } \\
\text { recovered is } 100 \% \text { sulfur. }\end{array}$ & $\begin{array}{l}\text { - NG and electricity demands: } \\
\text { product of each energy use factor } \\
\text { and the total mass of sulfur } \\
\text { recovered. }\end{array}$ & $\begin{array}{l}\text { - GHG emissions intensities: } \\
\text { product of a unit of energy } \\
\text { consumed and its corresponding } \\
\text { direct and indirect EF. }\end{array}$ \\
\hline \multirow[t]{12}{*}{ Utilities } & & \multirow[t]{4}{*}{ SMR } & Data & & & \\
\hline & & & $\begin{array}{l}\text { - Hydrogen demand from HCU, } \\
\text { naphtha HT, LGO HT, HGO HT. }\end{array}$ & - No data needed. & $\begin{array}{l}\text { - Energy use factors: NG used as } \\
\text { fuel, NG used as feeds tock, } \\
\text { steam and electricity } \\
\text { requirements per scf of hydrogen } \\
\text { produced. } \\
\text { - Amount of hydrogen demanded } \\
\text { by hydroprocessing units. }\end{array}$ & $\begin{array}{l}\text { - Energy use: NG, FG volume, } \\
\text { and electricity used by SMR. } \\
\text { - DirectEFs: NG and FG } \\
\text { combustion EFs, NG, FG } \\
\text { reaction EFs. } \\
\text { - Indirect EFs: NG upstream EF; } \\
\text { off-site electricity generation EF. }\end{array}$ \\
\hline & & & \begin{tabular}{|l|} 
Methods \\
\end{tabular} & & & \\
\hline & & & $\begin{array}{l}\text { - Assumption: hydrogen production } \\
\text { equals total hydrogen demand of } \\
\text { hydroprocessing units. }\end{array}$ & $\begin{array}{l}\text { - Assumption: product is pure } \\
\text { hydrogen gas. }\end{array}$ & $\begin{array}{l}- \text { NG, steam, and electricity } \\
\text { demands: product of energy use } \\
\text { factor and amount of hydrogen } \\
\text { produced. }\end{array}$ & $\begin{array}{l}\text { - GHG emissions intensities: } \\
\text { product of a unit of energy } \\
\text { consumed and its corresponding } \\
\text { direct and indirectEF. }\end{array}$ \\
\hline & & \multirow[t]{4}{*}{ BLRS } & Data & & & \\
\hline & & & $\begin{array}{l}\text { Total steam demand of process } \\
\text { units. }\end{array}$ & - No data needed. & $\begin{array}{l}\text { - Energy use factors: fuel and } \\
\text { electricity requirements per unit } \\
\text { mass of steam generated. } \\
\text { - Amount of steam demanded. } \\
\text { - Fraction of FG and/or coke } \\
\text { generation available as fuel. }\end{array}$ & $\begin{array}{l}\text { - Energy use: NG/FG volume, } \\
\text { coke mass, electricity of boilers. } \\
\text { - DirectEFs: NG, FG, and coke } \\
\text { combustion EFs. } \\
\text { - IndirectEFs: } N G \text { upstream EF; } \\
\text { off-site electricity generation EF. }\end{array}$ \\
\hline & & & Methods & & & \\
\hline & & & $\begin{array}{l}\text { - Assumption: steam production }= \\
\text { total steam demand of process } \\
\text { units. }\end{array}$ & $\begin{array}{l}\text { - Assumption: steam's quality is } \\
100 \text {. }\end{array}$ & $\begin{array}{l}\text { - Fuel, electricity demands: } \\
\text { product of energy use factor and } \\
\text { total amount of steam generated. } \\
\text { - Fractions of FG and coke } \\
\text { production input by user used as } \\
\text { substitutes of NG. }\end{array}$ & $\begin{array}{l}\text { - GHG emissions intensities: } \\
\text { product of a unit of energy } \\
\text { consumed and its corresponding } \\
\text { direct and indirect life cycle EF. }\end{array}$ \\
\hline & & \multirow[t]{4}{*}{ COGEN } & Data & & & \\
\hline & & & $\begin{array}{l}\text { - Desired am ount of electricity } \\
\text { generation. }\end{array}$ & - No data needed. & $\begin{array}{l}\text { - Efficiency of gas turbine. } \\
\text { - Efficiency of HRSG. } \\
\text { - Total electricity generation. }\end{array}$ & $\begin{array}{l}- \text { Energy use: total NG volume } \\
\text { used in cogeneration. } \\
\text { - DirectEFs: NG combustion EF. } \\
\text { - IndirectEFs: NG upstream EF. }\end{array}$ \\
\hline & & & Methods & & & \\
\hline & & & $\begin{array}{l}\text { - Assumption: amount of electricity } \\
\text { generation is defined by user. } \\
\text { - Heat recovery/steam: using } \\
\text { efficiencies of gas turbine and } \\
\text { HRSG. }^{28}\end{array}$ & $\begin{array}{l}\text { - Assumption: steam's quality is } \\
100 \text {. }\end{array}$ & $\begin{array}{l}\text { - NG demand of gas turbine: } \\
\text { quotient of electricity generated } \\
\text { and efficiency.28 } \\
\text { - NG demand of HRSG with } \\
\text { supplemental firing: heat } \\
\text { recovered by HRSG, HRSG duct } \\
\text { burner efficiency. }\end{array}$ & $\begin{array}{l}\text { - GHG emissions intensities: } \\
\text { product of a unit of energy } \\
\text { consumed and its corresponding } \\
\text { direct and indirect life cycle EF. }\end{array}$ \\
\hline
\end{tabular}


GHG: greenhouse gas; VR: vacuum residue; DC: delayed coking-based upgrading; HC: hydroconversion-based upgrading; HC/FC: combined hydroconversion and fluid coking-based upgrading; DRU: diluent recovery unit; VDU: vacuum distillation unit; DCU: delayed coker unit; EBH: ebullated-bed hydrocracker; FCU: fluid coker unit; HT: hydrotreater; LGO HT: light gas oil hydrotreater; HGO HT: heavy gas oil hydrotreater; AT/AR: amine treatment/amine regeneration units; SRU: sulfur recovery unit; SMR: steam methane reformer; BLRS: boilers; COGEN: cogeneration unit; HTSD: high-temperature simulated distillation; dilbit: diluted bitumen; NG: natural gas; FG: fuel gas; EF: emissions factor; Tb: average normal boiling point; Tb50: ; S: sulfur content; $\mathrm{N}$ : nitrogen content; H: hydrogen content; API: ; MCRT: micro carbon residue; $\mathrm{K}_{\mathrm{w}}$ : Watson characterization factor; s: specific gravity; MW: molecular weight; LSV: liquid space velocity; LHSV: liquid hourly space velocity; T: temperature; P: pressure; HDS: hydrodesulfurization; HDN: hydrodenitrogenation; $\mathrm{C} 1-\mathrm{C} 4$ : methane, ethane, propane and butane gases; $\mathrm{H}_{2} \mathrm{~S}$ : hydrogen sulphide; $\mathrm{NH}_{3}$ : ammonia; $\mathrm{Br}$ : bromine; Ar: Aromatics content; HRSG: heat recovery steam generator. 


\section{Methods: Modeling of OSTUM 2.0's DC-Based Multi-Product Upgrading Scheme}

Modeling of SCO Co-Products Yields and Composition. OSTUM 2.0 models the simultaneous production of a light sweet SCO blend, ULSD, and three medium to heavy sour SCO blends in its enhanced DC module. The model is able to model variations in product distribution by SCO blend that occur in realworld operations due to market demand and other factors. A user can adjust the desired volumetric yield and volumetric composition of each SCO blend to obtain upgrading products with specific quality properties (e.g., API, sulfur content). For example, to model heavier sour blends (i.e., blends with lower API values), the volume fraction of heavy gas oils may be increased. The portions of intermediate crude fractions that are hydrotreated also can be adjusted, so that the required volume of each product stream (i.e., different crude fractions being produced, like virgin gas oils, hydrotreated gas oils) is available at the blending stage. The volumes of intermediate crude fractions that are not hydrotreated are automatically available for final blending.

The light sweet SCO is a blend of hydrotreated naphtha, hydrotreated LGO, and hydrotreated HGO. Virgin and cracked LGOs are hydrotreated to obtain a product with properties similar to ULSD. To model the medium to heavy sour SCO blends, portions of the virgin gas oils and of the cracked fractions are routed to skip hydrotreating and are sent directly to product blending. A portion of hydrotreated naphtha may also be blended into the medium to heavy sour $\operatorname{scos}^{29}$ 


\section{Methodology to Allocate Upgrader's Energy Use Among its Co-Products.}

OSTUM 2.0 makes use of the co-product treatment method of allocation to partition the energy consumed by the upgrader among the various SCO blends at the process unit level. Three different allocation methods may be used: mass-based, energy-based, and hydrogen content-based. In each method, the energy consumed by a process unit is allocated among its throughputs in proportion to a weighting factor. More specifically, at any given process unit, the amount and type of energy consumed by the process unit (e.g., MJ of natural gas, MJ of steam) is aggregated to the energy embedded in the process unit's feed(s) and allocated to its throughputs in proportion to their mass, energy, or hydrogen content. This approach is applied to successive process units until all final product streams are produced. In this way, each final product stream carries a sum of certain energy burdens that is the share of the upgrader's total energy inputs required to produce that product stream. The share of total energy inputs allocated to each product stream is proportional to the type and level of processing. OSTUM 2.0 allows the flexibility of defining which byproducts (fuel gas, coke, sulfur) are considered waste streams (and therefore not assigned any fraction of energy use), and which ones are considered coproducts (therefore assigned a fraction of energy use and upgrader emissions). Once all product streams are allocated a fraction of the upgrader's energy use, each SCO blend receives a fraction of the energy allocated to each product stream proportional to the volume fraction of the said product stream in the blend. For example, for a SCO blend that mixes 90 vol\% of all the HGO produced and 20 vol\% of all the hydrotreated naphtha, the energy allocated to the SCO blend will be the summation of $90 \%$ of the energy burdens assigned to 
the HGO product and $20 \%$ of the energy burdens allocated to hydrotreated naphtha. 


\section{Methods: Modeling of OSTUM 2.0's HC-based Multi-Product Upgrading Scheme}

Modeling of SCO Co-Products Yields and Composition. OSTUM 2.0 models the simultaneous production of three SCO blends from $\mathrm{HC}$ : two light sweet SCO blends and one heavy sour SCO blend. According to Crudemonitor, ${ }^{10}$ the light sweet SCOs are blends of hydrotreated naphtha, hydrotreated LGO, and hydrotreated HGO. The heavy sour $\mathrm{SCO}^{30}$ is a blend of hydrotreated products, virgin distillates, and the ebullated-bed hydroconverter's unconverted residuum. Similarly to the enhanced DC module, portions of the virgin distillates skip hydrotreating and are sent directly to blending. The volumetric yield of each SCO blend, their volumetric composition, and the portions of virgin and hydrocracked distillates sent to hydrotreating are inputs to the model that can be adjusted, as described earlier in the DC module.

\section{Methodology to Allocate Upgrader's Energy Use Among its Co-Products.}

In the $\mathrm{HC}$ module, the energy consumed by the process units is allocated among the three SCO blends following the allocation procedure previously described for the DC module. 


\section{Methods: Estimation of Product Properties in All Modules}

To estimate the properties of intermediate crude fractions and final product streams, OSTUM 2.0 utilizes different methods at each upgrading stage. The first upgrading stage, diluent recovery and vacuum distillation, is common to the three upgrading technologies. Properties like API gravity, density, micro carbon residue, sulfur, and nitrogen contents of the crude fractions are approximated using assay data published by Crudemonitor. ${ }^{10}$ Correlations by Goossens ${ }^{11,13}$ and Choudhary et al. ${ }^{12}$ are employed to estimate the hydrogen content of these fractions.

The second upgrading stage (conversion) varies among the different technologies. The main product properties from DC's conversion stage (delayed coker unit's products) are estimated using two methods: the guidelines for distribution of sulfur and nitrogen in products proposed by Gary et al., ${ }^{15}$ and correlations of Maples $^{22}$ reported by Ancheyta ${ }^{16}$ that approximate API gravity. For HC's conversion stage products (ebullated-bed hydroconverter's products), sulfur and nitrogen contents are approximated by applying a kinetic model from Yui and Sanford. ${ }^{19}$ The values of API gravity of the hydroconverter's products are assumed as reported by Alvarez-Majmutov et al. ${ }^{20}$ since no correlation or kinetic model was found in the literature. The sulfur contents and API gravities of HC/FC's fluid coker products are approximated using correlations reported by Fahim et al. ${ }^{21}$ based on data compiled by Maples. ${ }^{22}$

The third upgrading stage (hydrotreating) is also common to all technologies. The properties of the hydrotreated naphtha (olefins, di-olefins, aromatics, sulfur, and nitrogen contents) are approximated by applying a kinetic model by Yui. ${ }^{23}$ 
The properties of the hydrotreated LGO and hydrotreated HGO (API gravity, aromatics, sulfur, and nitrogen contents) are estimated by applying a density correlation by Yui ${ }^{26}$ and kinetic models by Yui and Sanford. ${ }^{19,25}$ These kinetic models allow tuning the properties of the hydrotreated product streams by adjusting the operating conditions of the hydrotreaters (e.g., temperature, pressure). For example, the operating conditions of DC's LGO hydrotreater can be adjusted (e.g., $360^{\circ} \mathrm{C}, 5 \mathrm{MPa}$, hydrogen/oil ratio $\left.1,400 \mathrm{scf} / \mathrm{bbl}\right)^{31}$ to produce a hydrotreated LGO product with properties similar to those of ULSD (e.g., less than $15 \mathrm{ppm}$ sulfur, $5-7 \mathrm{ppm}$ nitrogen, and less than $35 \mathrm{wt} \%$ aromatics).$^{32}$ It is also possible to adjust the kinetic parameters (e.g., pre-exponential factors) of the three hydrotreaters to match a specific scenario outside the validity domain of the default parameters.

Once the properties of the product streams are approximated as described above, the properties of the SCO blends can be tuned by adjusting the volumetric fractions of the blends' components. For example, to increase the API gravity of a light sweet SCO blend, the volumetric fraction of hydrotreated naphtha can be increased. 


\section{Methods: Estimation of a Blend's Volumetric Shrinkage, Density, Specific Gravity and API Gravity}

The volumetric shrinkage in a blend of two hydrocarbons of known component volumes can be determined applying the following shrinkage formula: ${ }^{.3}$

$$
S=2.69 \times 10^{4} C(100-C)^{0.819}\left(\frac{1}{d L}-\frac{1}{d H}\right)^{2.28}
$$

where:

$S$ : volumetric shrinkage, as a \% of the total mixture ideal volume.

C: concentration, in \% liquid volume of the lighter component in the mixture.

$(1 / d L-1 / d H)$ : inverse density difference of the lighter $(d L)$ and heavier $(d H)$ components in $\mathrm{m}^{3} / \mathrm{kg}$.

Once the volumetric shrinkage is known, the resulting blend volume is calculated as: $:^{33}$

Resulting Blend Volume $=($ Sum of Component Volumes $)-($ Volumetric Shrinkage, $S)$

To determine the density of a blend of hydrocarbons, the resulting blend volume calculated above and the principle of conservation if mass are used: ${ }^{33}$

Original Mass $=$ Mass of Heavier Component + Mass of Lighter Component

Actual Blend Density = Original Mass $/$ Resulting Blend Volume

Specific gravity is calculated as the ratio of the Actual Blend Density and the density of water at $4{ }^{\circ} \mathrm{C}$ : 
API gravity is a measure of how heavy or light oil liquid is compared to water. If the oil's API gravity is greater than 10 then it is lighter and floats on water; if less than 10 , then it is heavier and sinks. API gravity is used to compare densities of oil liquids. ${ }^{3}$ For example, if an oil stream is less dense than another, it has a greater API gravity. API gravity can be calculated from specific gravity:

$$
\text { API Gravity }=\frac{141.5}{\text { Specific Gravity }}-131.5
$$




\section{Methods: Delayed Coking Based Upgrading Base Scenario Input Parameters and Assumptions}

Table S3. Input parameters and assumptions of OSTUM 2.0's delayed coking based upgrading base scenario.

\begin{tabular}{|c|c|}
\hline Feedstock & $\begin{array}{l}\text { - Type of dilbit: Borealis Heav Blend (BHB) } \\
\text { - Dilbit volumetric flow rate: } 529,576 \text { bpd }^{*} \\
\text { - Bitumen volumetric flow rate: } 370,637 \text { bpd }\end{array}$ \\
\hline Electricity Supply & - $100 \%$ of electricity requirements supplied by on-site cogeneration* \\
\hline Energy Inputs to Upgrader & $\begin{array}{l}\text { - Fuels: natural gas, fuel (process) gas, and coke consumed for heat, } \\
\text { steam, hydrogen, and electricity generation } \\
\text { - Energy inputs: off-site produced natural gas, on-site generated fuel gas, } \\
\text { on-site generated coke, on-site generated steam, on-site generated } \\
\text { hydrogen, and on-site cogenerated electricity and steam }\end{array}$ \\
\hline Products & $\begin{array}{l}\text { - Light sweet SCO blends: similar to Suncor Synthetic A (OSA), similar to } \\
\text { - Suncor's ultra-low sulfur diesel (ULSD) } \\
\text { - Heavy sour SCO blends: similar to Suncor Synthetic H (OSH), similar to } \\
\text { Suncor Cracked C (OCC) } \\
\text { - Medium sour SCO blend }\end{array}$ \\
\hline By-products & $\begin{array}{l}\text { - Fuel gas } \\
\text { - Coke }\end{array}$ \\
\hline Disposition of By-products & $\begin{array}{l}\text { - Fuel gas: } 64 \% \text { of fuel gas production used as fuel in process heaters* } \\
\text { - Coke: } 15 \% \text { of coke production used as fuel in boilers* }\end{array}$ \\
\hline Upgrading Emissions & - GHGs: $\mathrm{CO}_{2}, \mathrm{CH}_{4}, \mathrm{~N}_{2} \mathrm{O}$ reported as $\mathrm{CO}_{2}$ equivalents $\left(\mathrm{CO}_{2} \mathrm{e}\right)$ \\
\hline Heating Values of Fuels & - Lower heating values (LHVs) \\
\hline Diluent Recovery Unit & $\begin{array}{l}\text { - Natural gas use: } 88.0 \mathrm{scf} / \mathrm{bbl} \text { feed (avg. of }{ }^{15,22,34} \text { ) } \\
\text { - Electricity use: } 0.7 \mathrm{kWh} / \mathrm{bbl} \text { feed (avg. of }{ }^{15,22,34} \text { ) } \\
\text { - Steam use: } 17.5 \mathrm{lb} / \mathrm{bbl} \text { feed (avg. of }{ }^{15,22} \text { ) } \\
\end{array}$ \\
\hline Vacuum Distillation Unit & $\begin{array}{l}\text { - Natural gas use: } 79.0 \mathrm{scf} / \mathrm{bbl} \text { feed (avg. of }{ }^{15,22,34} \text { ) } \\
\text { - Electricity use: } 0.4 \mathrm{kWh} / \mathrm{bbl} \text { feed (avg. of }{ }^{15,22,34} \text { ) } \\
\text { - Steam use: } 30.0 \mathrm{lb} / \mathrm{bbl} \text { feed (avg. of }{ }^{15,22} \text { ) } \\
\end{array}$ \\
\hline Delayed Coker & $\begin{array}{l}\text { - Natural gas use: } 145.2 \mathrm{scf} / \mathrm{bbl} \text { feed (avg. of }{ }^{15,22,21,35} \text { ) } \\
\text { - Electricity use: } 2.2 \mathrm{kWh} / \mathrm{bbl} \text { feed (avg. of }{ }^{15,22,27,35,36} \text { ) } \\
\text { - Steam use: } 41.0 \mathrm{lb} / \mathrm{bbl} \text { feed (avg. of }{ }^{15,22} \text { ) } \\
\text { - Temperature: } 842.0^{\circ} \mathrm{F}\left(\text { avg. of }{ }^{6,20} \text { ) }\right. \\
\text { - Pressure: } 10.0 \mathrm{psig}\left({ }^{27}\right)\end{array}$ \\
\hline Naphtha Hydrotreater & $\begin{array}{l}\text { - Natural gas use: } 874.7 \mathrm{scf} / \text { ton feed }\left({ }^{15}\right) \\
\text { - Electricity use: } 16.3 \mathrm{kWh} / \mathrm{ton} \text { feed }\left({ }^{15}\right) \\
\text { - Steam use: } 6.0 \mathrm{lb} / \mathrm{bbl} \text { feed }\left({ }^{15}\right) \\
\text { - Feed's bromine number: } 80.0 \mathrm{gBr} / 100 \mathrm{~g}(\text { avg. of } 9,23,37) \\
\text { - Feed's diene number: } 10.0 \mathrm{gl} / 100 \mathrm{~g}\left(\text { avg. of }{ }_{9,23,37}\right) \\
\left.\text { - Feed's aromatics content: } 27.8 \mathrm{wt} \% \text { (avg. of }{ }^{20,23,37}\right) \\
\text { - Temperature: } 285.0{ }^{\circ} \mathrm{C}\left({ }^{20}\right) \\
\text { - Pressure: } 4.0 \mathrm{MPa}\left({ }^{20}\right) \\
\text { - } \mathrm{H}_{2} / \text { Oil ratio: } 1,680.0 \mathrm{scf} \mathrm{H}_{2} / \mathrm{bbl} \text { feed }\left({ }^{20}\right) \\
\end{array}$ \\
\hline LGO Hydrotreater & $\begin{array}{l}\text { - Natural gas use: } 1,143.1 \mathrm{scf} / \text { ton feed }\left({ }^{15}\right) \\
\text { - Electricity use: } 21.3 \mathrm{kWh} / \mathrm{ton} \text { feed }\left({ }^{15}\right) \\
\text { - Steam use: } 8.0 \mathrm{lb} / \mathrm{bbl} \text { feed }\left({ }^{15}\right) \\
\left.\text { - Feed's aromatics content: } 46.8 \mathrm{wt} \% \text { (avg. of }{ }^{9,20,25}\right) \\
\text { - Temperature: } 360.0{ }^{\circ} \mathrm{C}\left({ }^{31}\right) \\
\text { - Pressure: } 5.0 \mathrm{MPa}\left({ }^{31}\right) \\
\text { - } \mathrm{H}_{2} / \text { Oil ratio: } 1,400.0 \mathrm{scf} \mathrm{H}_{2} / \mathrm{bbl} \text { feed }\left({ }^{31}\right)\end{array}$ \\
\hline
\end{tabular}




\begin{tabular}{|c|c|}
\hline HGO Hydrotreater & $\begin{array}{l}\text { - Natural gas use: } 1,387.2 \mathrm{scf} / \text { ton feed }\left({ }^{15}\right) \\
\text { - Electricity use: } 38.6 \mathrm{kWh} / \text { ton feed }\left({ }^{15}\right) \\
\text { - Steam use: } 10.0 \mathrm{lb} / \mathrm{bbl} \text { feed }\left({ }^{15}\right) \\
\text { - Feed's aromatics content: } 62.0 \mathrm{wt} \%\left(\text { avg. of }{ }^{9,20,25}\right) \\
\text { - Temperature: } 370.0{ }^{\circ} \mathrm{C}\left({ }^{20}\right) \\
\text { - Pressure: } 9.0 \mathrm{MPa}\left({ }^{20}\right) \\
\text { - } \mathrm{H}_{2} / \text { Oil ratio: } 3,370.0 \mathrm{scf} \mathrm{H}_{2} / \mathrm{bbl} \text { feed }\left({ }^{20}\right)\end{array}$ \\
\hline $\begin{array}{l}\text { Amine Treatment / Amine } \\
\text { Regeneration }\end{array}$ & $\begin{array}{l}\text { - Electricity use: } 21.7 \mathrm{kWh} / \text { ton feed (avg. of }{ }^{27,38} \text { ) } \\
\text { - Steam use: } 822.2 \mathrm{lb} / \text { ton feed (avg. of }{ }^{27,39} \text { ) }\end{array}$ \\
\hline Sulfur Recovery Unit & $\begin{array}{l}\text { - Sulfur recovery - natural gas use: } 204.2 \mathrm{scf} / \text { ton sulfur produced }\left({ }^{35}\right) \\
\text { - Sulfur recovery - electricity use: } 65.8 \mathrm{kWh} / \text { ton sulfur produced (avg. of } \\
\text { - Sulfur recovery - steam production: } 5,732.0 \mathrm{lb} / \text { ton sulfur produced (avg. } \\
\text { of }{ }^{15,35} \text { ) } \\
\text { - Tail gas treatment - natural gas use: } 816.7 \mathrm{scf} / \text { ton sulfur produced }\left({ }^{35}\right) \\
\text { - Tail gas treatment - electricity use: } 245.5 \mathrm{kWh} / \text { ton sulfur produced (avg. } \\
\text { of }{ }^{15,35} \text { ) } \\
\text { - Sulfur recovery - sulfur yield: } 95.0 \mathrm{~mol} \% \text { of sulfur in feed }\left({ }^{27}\right) \\
\text { - Tail gas treatment - sulfur yield: } 95.0 \mathrm{~mol} \% \text { of sulfur in feed }\left({ }^{27}\right)\end{array}$ \\
\hline Steam Methane Reformer & $\begin{array}{l}\text { - Natural gas use as fuel: } 0.04 \mathrm{scf} / \mathrm{scf} \text { hydrogen produced }\left({ }^{40}\right) \\
\text { - Natural gas use as feedstock: } 0.34 \mathrm{scf} / \mathrm{scf} \text { hydrogen produced }\left({ }^{40}\right) \\
\text { - Steam use: } 0.05 \mathrm{lb} / \mathrm{scf} \text { hydrogen produced }\left({ }^{40}\right) \\
\text { - Steam production: } 0.07 \mathrm{lb} / \mathrm{scf} \text { hydrogen produced }\left({ }^{40}\right) \\
\text { - Electricity use: } 0.0007 \mathrm{kWh} / \mathrm{scf} \text { hydrogen produced }\left({ }^{40}\right)\end{array}$ \\
\hline Boilers & $\begin{array}{l}\text { - Fuel use: } 3.3 \mathrm{MJ} / \mathrm{kg} \text { steam produced }\left(^{27}\right) \\
\text { - Electricity use: } 0.005 \mathrm{kWh} / \mathrm{kg} \text { steam produced }\left({ }^{27}\right)\end{array}$ \\
\hline Cogeneration & $\begin{array}{l}\text { - Efficiency of gas turbine: } 30.0 \%\left({ }^{41}\right) \\
\text { - Efficiency of heat recovery steam generator - recovery of exhaust heat } \\
\text { from gas turbine: } 50.0 \%\left({ }^{41}\right) \\
\text { - Efficiency of heat recovery steam generator - using supplemental firing: } \\
95.0 \% \text { (avg. of }{ }^{41,42} \text { ) } \\
\text { - Electricity produced: } 80.0 \mathrm{MW}^{*}\end{array}$ \\
\hline
\end{tabular}

Notes: * Indicates values of input parameters informed by the median of the data reported to AER by Suncor after the latest known modification to their upgrading operations (2008) to the end of 2016. 


\section{Methods: Hydroconversion Based Upgrading Base Scenario Input Parameters and Assumptions}

Table S4. Input parameters and assumptions of hydroconversion based upgrading base scenario.

\begin{tabular}{|c|c|}
\hline Feedstock & $\begin{array}{l}\text { - Type of dilbit: Borealis Heav Blend (BHB) } \\
\text { - Dilbit volumetric flow rate: } 322,826 \text { bpd }^{*} \\
\text { - Bitumen volumetric flow rate: } 225,938 \text { bpd }\end{array}$ \\
\hline $\begin{array}{l}\text { Electricity Generation } \\
\text { Technology }\end{array}$ & $\begin{array}{l}\text { - } 90 \% \text { of electricity requirements supplied by on-site cogeneration* } \\
\text { - } 10 \% \text { of electricity requirements supplied by grid }\end{array}$ \\
\hline Energy Inputs to Upgrader & $\begin{array}{l}\text { - Fuels: natural gas and fuel (process) gas consumed for heat, steam, } \\
\text { hydrogen, and electricity generation } \\
\text { - Energy inputs: off-site produced natural gas; on-site generated fuel gas, } \\
\text { steam, hydrogen, and cogenerated electricity and steam }\end{array}$ \\
\hline Products & $\begin{array}{l}\text { - Light sweet SCO blends: similar to Shell's Premium Albian Synthetic } \\
\text { (PAS), similar to Shell Synthetic Light (SSX) } \\
\text { - Heavy sour SCO blend: similar to Albian Heavy Synthetic (AHS) }\end{array}$ \\
\hline By-products & - Fuel gas \\
\hline Disposition of By-products & $\begin{array}{l}\text { - Fuel gas: } 100 \% \text { of production used as fuel in process heaters, boilers, } \\
\text { and as steam methane reformer's feedstock for hydrogen production* }\end{array}$ \\
\hline Upgrading Emissions & - GHGs: $\mathrm{CO}_{2}, \mathrm{CH}_{4}, \mathrm{~N}_{2} \mathrm{O}$ reported as $\mathrm{CO}_{2}$ equivalents $\left(\mathrm{CO}_{2} \mathrm{e}\right)$ \\
\hline Heating Values of Fuels & - Lower heating values (LHVs) \\
\hline Diluent Recovery Unit & $\begin{array}{l}\text { - Natural gas use: } 88.0 \mathrm{scf} / \mathrm{bbl} \text { feed (avg. of }{ }^{15,22,34} \text { ) } \\
\text { - Electricity use: } 0.7 \mathrm{kWh} / \mathrm{bbl} \text { feed (avg. of }{ }^{15,22,34} \text { ) } \\
\text { - Steam use: } 17.5 \mathrm{lb} / \mathrm{bbl} \text { feed (avg. of }{ }^{15,22} \text { ) } \\
\end{array}$ \\
\hline Vacuum Distillation Unit & $\begin{array}{l}\text { - Natural gas use: } 79.0 \mathrm{scf} / \mathrm{bbl} \text { feed (avg. of }{ }^{15,22,34} \text { ) } \\
\text { - Electricity use: } 0.4 \mathrm{kWh} / \mathrm{bbl} \text { feed (avg. of }{ }^{15,22,34} \text { ) } \\
\text { - Steam use: } 30.0 \mathrm{lb} / \mathrm{bbl} \text { feed (avg. of }{ }^{15,22} \text { ) } \\
\end{array}$ \\
\hline $\begin{array}{l}\text { Ebullated-bed } \\
\text { Hydrocracker }\end{array}$ & $\begin{array}{l}\text { - Natural gas use: } 125.9 \mathrm{scf} / \mathrm{bbl} \text { feed }\left({ }^{22}\right) \\
\text { - Electricity use: } 16.5 \mathrm{kWh} / \mathrm{bbl} \text { feed }\left({ }^{43}\right) \\
\text { - Steam use: } 149.9 \mathrm{lb} / \text { ton feed }\left(^{27}\right) \\
\text { - Temperature: } 440.0{ }^{\circ} \mathrm{C}\left({ }^{3}\right) \\
\text { - Pressure: } 15.0 \mathrm{MPa}\left({ }^{3}\right) \\
\text { - Residence time: } 2.5 \mathrm{~h}\left({ }^{20}\right) \\
\text { - } \mathrm{H}_{2} / \text { Oil ratio: } 10,000.0 \mathrm{scf} \mathrm{H}_{2} / \mathrm{bbl} \text { feed }\left({ }^{20}\right)\end{array}$ \\
\hline Naphtha Hydrotreater & $\begin{array}{l}\text { - Natural gas use: } 844.0 \mathrm{scf} / \text { ton feed }\left({ }^{15}\right) \\
\text { - Electricity use: } 15.7 \mathrm{kWh} / \mathrm{ton} \text { feed }\left({ }^{15}\right) \\
\text { - Steam use: } 5.8 \mathrm{lb} / \mathrm{bbl} \text { feed }\left({ }^{15}\right) \\
\text { - Feed's bromine number: } 13.0 \mathrm{gBr}_{2} / 100 \mathrm{~g}\left({ }^{9}\right) \\
\text { - Feed's diene number: } 0.0 \mathrm{gl}_{2} / 100 \mathrm{~g}\left({ }^{9,37}\right) \\
\text { - Feed's aromatics content: } 20.0 \mathrm{wt} \%\left({ }^{9,20,37}\right) \\
\text { - Temperature: } 275.0{ }^{\circ} \mathrm{C}\left({ }^{20}\right) \\
\text { - Pressure: } 4.0 \mathrm{MPa}\left({ }^{20}\right) \\
\text { - } \mathrm{H}_{2} / \text { Oil ratio: } 1,680.0 \mathrm{scf} \mathrm{H}_{2} / \mathrm{bbl} \text { feed }\left({ }^{20}\right)\end{array}$ \\
\hline LGO Hydrotreater & $\begin{array}{l}\text { - Natural gas use: } 1,063.8 \mathrm{scf} / \text { ton feed }\left({ }^{15}\right) \\
\text { - Electricity use: } 19.8 \mathrm{kWh} / \text { ton feed }\left({ }^{15}\right) \\
\text { - Steam use: } 7.4 \mathrm{lb} / \mathrm{bbl} \text { feed }\left({ }^{15}\right) \\
\text { - Feed's aromatics content: } 38.9 \mathrm{wt} \%\left({ }^{9,20,25}\right) \\
\text { - Temperature: } 335.0{ }^{\circ} \mathrm{C}\left({ }^{20}\right) \\
\text { - Pressure: } 5.0 \mathrm{MPa}\left({ }^{20}\right) \\
\text { - } \mathrm{H}_{2} / \text { Oil ratio: } 1,680.0 \mathrm{scf} \mathrm{H}_{2} / \mathrm{bbl} \text { feed }\left({ }^{20}\right)\end{array}$ \\
\hline
\end{tabular}




\begin{tabular}{|c|c|}
\hline HGO Hydrotreater & $\begin{array}{l}\text { - Natural gas use: } 1,361.0 \mathrm{scf} / \text { ton feed }\left({ }^{15}\right) \\
\text { - Electricity use: } 37.9 \mathrm{kWh} / \text { ton feed }\left({ }^{15}\right) \\
\text { - Steam use: } 9.8 \mathrm{lb} / \mathrm{bbl} \text { feed }\left({ }^{15}\right) \\
\text { - Feed's aromatics content: } 55.3 \mathrm{wt} \%\left({ }^{9,20,25}\right) \\
\text { - Temperature: } 363.0^{\circ} \mathrm{C}\left({ }^{20}\right) \\
\text { - Pressure: } 9.0 \mathrm{MPa}\left({ }^{20}\right) \\
\text { - } \mathrm{H}_{2} / \text { Oil ratio: } 3,370.0 \mathrm{scf} \mathrm{H}_{2} / \mathrm{bbl} \text { feed }\left({ }^{20}\right)\end{array}$ \\
\hline $\begin{array}{l}\text { Amine Treatment / Amine } \\
\text { Regeneration }\end{array}$ & $\begin{array}{l}\text { - Electricity use: } 21.7 \mathrm{kWh} / \text { ton feed }\left(\text { avg. }_{\text {. }}{ }^{27,38} \text { ) }\right. \\
\text { - Steam use: } 822.2 \mathrm{lb} / \text { ton feed (avg. } \text { of }^{27,39} \text { ) }\end{array}$ \\
\hline Sulfur Recovery Unit & $\begin{array}{l}\text { - Sulfur recovery - natural gas use: } 204.2 \mathrm{scf} / \text { ton sulfur produced }\left({ }^{35} \text { ) }\right. \\
\text { - Sulfur recovery - electricity use: } 65.8 \mathrm{kWh} / \text { ton sulfur produced (avg. of } \\
\text { - Sulfur recovery - steam production: } 5,732.0 \mathrm{lb} / \text { ton sulfur produced (avg. } \\
\text { of }{ }^{15,35} \text { ) } \\
\text { - Tail gas treatment - natural gas use: } 816.7 \mathrm{scf} / \text { ton sulfur produced }\left({ }^{35}\right) \\
\text { - Tail gas treatment - electricity use: } 245.5 \mathrm{kWh} / \text { ton sulfur produced (avg. } \\
\text { of }{ }^{15,35} \text { ) } \\
\text { - Sulfur recovery - sulfur yield: } 95.0 \mathrm{~mol} \% \text { of sulfur in feed }\left({ }^{27}\right) \\
\text { - Tail gas treatment - sulfur yield: } 95.0 \mathrm{~mol} \% \text { of sulfur in feed }\left({ }^{27}\right)\end{array}$ \\
\hline Steam Methane Reformer & $\begin{array}{l}\text { - Natural gas use as fuel: } 0.04 \mathrm{scf} / \mathrm{scf} \text { hydrogen produced }\left({ }^{40}\right) \\
\text { - Natural gas use as feedstock: } 0.34 \mathrm{scf} / \mathrm{scf} \text { hydrogen produced }\left({ }^{40}\right) \\
\text { - Steam use: } 0.05 \mathrm{lb} / \mathrm{scf} \text { hydrogen produced }\left({ }^{40}\right) \\
\text { - Steam production: } 0.07 \mathrm{lb} / \mathrm{scf} \text { hydrogen produced }\left({ }^{40}\right) \\
\text { - Electricity use: } 0.0007 \mathrm{kWh} / \mathrm{scf} \text { hydrogen produced }\left({ }^{40}\right)\end{array}$ \\
\hline Boilers & $\begin{array}{l}\text { - Fuel use: } 3.3 \mathrm{MJ} / \mathrm{kg} \text { steam produced }\left({ }^{2 T}\right) \\
\text { - Electricity use: } 0.005 \mathrm{kWh} / \mathrm{kg} \text { steam produced }\left({ }^{27}\right)\end{array}$ \\
\hline Cogeneration & $\begin{array}{l}\text { - Efficiency of gas turbine: } 30.0 \%\left({ }^{41}\right) \\
\text { - Efficiency of heat recovery steam generator - recovery of exhaust heat } \\
\text { from gas turbine: } 50.0 \%\left({ }^{41}\right) \\
\text { - Efficiency of heat recovery steam generator - using supplemental firing: } \\
95.0 \% \text { (avg. of }{ }^{41,42} \text { ) } \\
\text { - Electricity produced: } 282.0 \mathrm{MW}^{*}\end{array}$ \\
\hline
\end{tabular}

Notes: * Indicates values of input parameters informed by the median of the data reported to AER by Shell after the latest known modification to their upgrading operations (2011) to the end of 201 


\section{Methods: Combined Hydroconversion and Fluid Coking Based Upgrading Base Scenario Input Parameters and Assumptions}

Table S5. Input parameters, assumptions of combined hydroconversion and fluid coking based upgrading base scenario.

\begin{tabular}{|c|c|}
\hline Feedstock & $\begin{array}{l}\text { - Type of dilbit: Borealis Heavy Blend }(\mathrm{BHB}) \\
\text { - Dilbit volumetric flow rate: } 501,896 \text { bpd }^{*} \\
\text { - Bitumen volumetric flow rate: } 351,264 \text { bpd }\end{array}$ \\
\hline $\begin{array}{l}\text { Electricity Generation } \\
\text { Technology }\end{array}$ & $\begin{array}{l}\text { - } 72 \% \text { of electricity requirements supplied by on-site cogeneration* } \\
\text { - } 28 \% \text { of electricity requirements supplied by grid }\end{array}$ \\
\hline $\begin{array}{l}\text { Energy Inputs to } \\
\text { Upgrader }\end{array}$ & $\begin{array}{l}\text { - Fuels: natural gas, fuel (process) gas, and coke consumed for heat, } \\
\text { steam, hydrogen, and electricity generation } \\
\text { - Energy inputs: off-site produced natural gas, on-site generated fuel gas, } \\
\text { on-site generated coke, on-site generated steam, on-site generated } \\
\text { hydrogen, and on-site cogenerated electricity and steam }\end{array}$ \\
\hline Products & - Light sweet SCO blend: similar to Syncrude Sweet Premium (SSP) \\
\hline By-products & $\begin{array}{l}\text { - Fuel gas } \\
\text { - Coke } \\
\end{array}$ \\
\hline $\begin{array}{l}\text { Disposition of By- } \\
\text { products }\end{array}$ & $\begin{array}{l}\text { - Fuel gas: } 100 \% \text { of fuel gas production used as fuel in process heaters } \\
\text { and boilers } \\
\text { - Coke: } 21 \% \text { of coke production used as fuel in fluid coker }\end{array}$ \\
\hline Upgrading Emissions & - GHGs: $\mathrm{CO}_{2}, \mathrm{CH}_{4}, \mathrm{~N}_{2} \mathrm{O}$ reported as $\mathrm{CO}_{2}$ equivalents $\left(\mathrm{CO}_{2} \mathrm{e}\right)$ \\
\hline Heating Values of Fuels & - Lower heating values (LHVs) \\
\hline Diluent Recovery Unit & $\begin{array}{l}\text { - Natural gas use: } 88.0 \mathrm{scf} / \mathrm{bbl} \text { feed (avg. of }{ }^{15,22,34} \text { ) } \\
\text { - Electricity use: } 0.7 \mathrm{kWh} / \mathrm{bbl} \text { feed }\left(\operatorname{avg}_{\text {. of }}{ }^{15,22,34} \text { ) }\right. \\
\text { - Steam use: } 17.5 \mathrm{lb} / \mathrm{bbl} \text { feed (avg. of }{ }^{15,22} \text { ) } \\
\end{array}$ \\
\hline Vacuum Distillation Unit & $\begin{array}{l}\text { - Natural gas use: } 79.0 \mathrm{scf} / \mathrm{bbl} \text { feed (avg. of }{ }^{15,22,34} \text { ) } \\
\text { - Electricity use: } 0.4 \mathrm{kWh} / \mathrm{bbl} \text { feed (avg. of }{ }^{15,22,34} \text { ) } \\
\text { - Steam use: } 30.0 \mathrm{lb} / \mathrm{bbl} \text { feed (avg. of }{ }^{15,22} \text { ) }\end{array}$ \\
\hline $\begin{array}{l}\text { Ebullated-bed } \\
\text { Hydrocracker }\end{array}$ & $\begin{array}{l}\text { - Natural gas use: } 85.0 \mathrm{scf} / \mathrm{bbl} \text { feed }\left({ }^{22}\right) \\
\text { - Electricity use: } 13.9 \mathrm{kWh} / \mathrm{bbl} \text { feed }\left({ }^{43}\right) \\
\text { - Steam use: } 149.9 \mathrm{lb} / \mathrm{ton} \text { feed }\left({ }^{27}\right) \\
\text { - Temperature: } 425.0{ }^{\circ} \mathrm{C}\left({ }^{3}\right) \\
\text { - Pressure: } 10.0 \mathrm{MPa}\left({ }^{3}\right) \\
\text { - Residence time: } 2.5 \mathrm{~h}\left({ }^{20}\right) \\
\text { - } \mathrm{H}_{2} / \text { Oil ratio: } 10,000.0 \mathrm{scf} \mathrm{H}_{2} / \mathrm{bbl} \text { feed }\left({ }^{20}\right)\end{array}$ \\
\hline Fluid Coker & $\begin{array}{l}\text { - Coke use: } 21.0 \mathrm{wt} \% \text { coke production* } \\
\text { - Electricity use: } 30.0 \mathrm{kWh} / \mathrm{bbl} \text { feed }\left({ }^{43}\right) \\
\text { - Steam use: } 100.0 \mathrm{lb} / \mathrm{bbl} \text { feed }\left({ }^{43}\right)\end{array}$ \\
\hline Naphtha Hydrotreater & $\begin{array}{l}\text { - Natural gas use: } 874.7 \mathrm{scf} / \text { ton feed }\left({ }^{15}\right) \\
\text { - Electricity use: } 16.3 \mathrm{kWh} / \mathrm{ton} \text { feed }\left({ }^{15}\right) \\
\text { - Steam use: } 6.0 \mathrm{lb} / \mathrm{bbl} \text { feed }\left({ }^{15}\right) \\
\text { - Feed's bromine number: } 35.3 \mathrm{gBr} / 100 \mathrm{~g}\left({ }^{9}\right) \\
\text { - Feed's diene number: } 3.3 \mathrm{gl}_{2} / 100 \mathrm{~g}\left({ }^{9}\right) \\
\text { - Feed's aromatics content: } 22.0 \mathrm{wt} \%\left({ }^{9,23,37}\right) \\
\text { - Temperature: } 285.0{ }^{\circ} \mathrm{C}\left({ }^{20}\right) \\
\text { - Pressure: } 4.0 \mathrm{MPa}\left({ }^{20}\right) \\
\text { - } \mathrm{H}_{2} / \text { Oil ratio: } 1,680.0 \text { scf } \mathrm{H}_{2} / \mathrm{bbl} \text { feed }\left({ }^{20}\right)\end{array}$ \\
\hline
\end{tabular}




\begin{tabular}{|c|c|}
\hline LGO Hydrotreater & $\begin{array}{l}\text { - Natural gas use: } 1,143.1 \mathrm{scf} / \text { ton feed }\left({ }^{15}\right) \\
\text { - Electricity use: } 21.3 \mathrm{kWh} / \text { ton feed }\left({ }^{15}\right) \\
\text { - Steam use: } 8.0 \mathrm{lb} / \mathrm{bbl} \text { feed }\left({ }^{15}\right) \\
\text { - Feed's aromatics content: } 44.1 \mathrm{wt} \%\left({ }^{9,25}\right) \\
\text { - Temperature: } 335.0{ }^{\circ} \mathrm{C}\left({ }^{27}\right) \\
\text { - Pressure: } 5.0 \mathrm{MPa}\left({ }^{20}\right) \\
\text { - } \mathrm{H}_{2} / \text { Oil ratio: } 1,680.0 \mathrm{scf} \mathrm{H}_{2} / \mathrm{bbl} \text { feed }\left({ }^{20}\right)\end{array}$ \\
\hline HGO Hydrotreater & $\begin{array}{l}\text { - Natural gas use: } 1,387.2 \mathrm{scf} / \text { ton feed }\left({ }^{15}\right) \\
\text { - Electricity use: } 38.6 \mathrm{kWh} / \text { ton feed }\left({ }^{15}\right) \\
\text { - Steam use: } 10.0 \mathrm{lb} / \mathrm{bbl} \text { feed }\left({ }^{15}\right) \\
\text { - Feed's aromatics content: } 62.0 \mathrm{wt} \%\left({ }^{9,25}\right) \\
\text { - Temperature: } 363.0{ }^{\circ} \mathrm{C}\left({ }^{20}\right) \\
\text { - Pressure: } 9.0 \mathrm{MPa}\left({ }^{20}\right) \\
\text { - } \mathrm{H}_{2} / \text { Oil ratio: } 3,370.0 \mathrm{scf} \mathrm{H}_{2} / \mathrm{bbl} \text { feed }\left({ }^{20}\right) \\
\end{array}$ \\
\hline $\begin{array}{l}\text { Amine Treatment / Amine } \\
\text { Regeneration }\end{array}$ & $\begin{array}{l}\text { - Electricity use: } 21.7 \mathrm{kWh} / \text { ton feed (avg. of }{ }^{27,38} \text { ) } \\
\text { - Steam use: } 822.2 \mathrm{lb} / \text { ton feed (avg. of }{ }^{27,39} \text { ) }\end{array}$ \\
\hline Sulfur Recovery Unit & $\begin{array}{l}\text { - Sulfur recovery - natural gas use: } 204.2 \mathrm{scf} / \text { ton sulfur produced }\left({ }^{35}\right) \\
\text { - Sulfur recovery - electricity use: } 65.8 \mathrm{kWh} / \text { ton sulfur produced (avg. of } \\
\text { - Sulfur recovery - steam production: } 5,732.0 \mathrm{lb} / \text { ton sulfur produced } \\
\text { (avg. of }{ }^{15,35} \text { ) } \\
\text { - Tail gas treatment - natural gas use: } 816.7 \mathrm{scf} / \text { ton sulfur produced }\left({ }^{35}\right) \\
\text { - Tail gas treatment - electricity use: } 245.5 \mathrm{kWh} / \text { ton sulfur produced } \\
\text { (avg. of }{ }^{15,35} \text { ) } \\
\text { - Sulfur recovery - sulfur yield: } 95.0 \mathrm{~mol} \% \text { of sulfur in feed }\left({ }^{27}\right) \\
\text { - Tail gas treatment - sulfur yield: } 95.0 \mathrm{~mol} \% \text { of sulfur in feed }\left({ }^{27}\right)\end{array}$ \\
\hline Steam Methane Reformer & $\begin{array}{l}\text { - Natural gas use as fuel: } 0.04 \mathrm{scf} / \mathrm{scf} \text { hydrogen produced }\left({ }^{40}\right) \\
\text { - Natural gas use as feedstock: } 0.34 \mathrm{scf} / \mathrm{scf} \text { hydrogen produced }\left({ }^{40}\right) \\
\text { - Steam use: } 0.05 \mathrm{lb} / \mathrm{scf} \text { hydrogen produced }\left({ }^{40}\right) \\
\text { - Steam production: } 0.07 \mathrm{lb} / \mathrm{scf} \text { hydrogen produced }\left({ }^{40}\right) \\
\text { - Electricity use: } 0.0007 \mathrm{kWh} / \mathrm{scf} \text { hydrogen produced }\left({ }^{40}\right)\end{array}$ \\
\hline Boilers & $\begin{array}{l}\text { - Fuel use: } 3.3 \mathrm{MJ} / \mathrm{kg} \text { steam produced }\left({ }^{27}\right) \\
\text { - Electricity use: } 0.005 \mathrm{kWh} / \mathrm{kg} \text { steam produced }\left({ }^{27}\right)\end{array}$ \\
\hline Cogeneration & $\begin{array}{l}\text { - Efficiency of gas turbine: } 30.0 \%\left({ }^{41}\right) \\
\text { - Efficiency of heat recovery steam generator - recovery of exhaust heat } \\
\text { from gas turbine: } 50.0 \%\left({ }^{41}\right) \\
\text { - Efficiency of heat recovery steam generator - using supplemental } \\
\text { firing: } 95.0 \% \text { (avg. of }{ }^{41,42} \text { ) } \\
\text { - Electricity produced: } 252.00 \mathrm{MW}\end{array}$ \\
\hline
\end{tabular}

Notes: * Indicates values of input parameters informed by the median of the data reported to AER by Syncrude after the latest known modification to their upgrading operations (2007) to the end of 2016. 


\section{Methods: Main Quality Properties of Commercial SCO Blends Used to Guide OSTUM 2.0's Base Scenarios}

Table S6. Five-year average product quality data reported by Crudemonitor, ${ }^{10}$ unless other reference is indicated.

\begin{tabular}{|c|c|c|c|c|c|c|c|c|c|}
\hline & $\begin{array}{c}\text { Suncor } \\
\text { Synthetic } \\
\text { A } \\
\text { (OSA) }\end{array}$ & ULSD & $\begin{array}{c}\text { Suncor } \\
\text { Synthetic } \\
\text { H } \\
\text { (OSH) }\end{array}$ & $\begin{array}{c}\text { Suncor } \\
\text { Cracked } \\
\text { C } \\
\text { (OCC) }\end{array}$ & $\begin{array}{c}\text { Suncor's } \\
\text { Petro Can } \\
\text { Oil Sands } \\
\text { Heavy } \\
\text { (OSP) } \\
\end{array}$ & $\begin{array}{l}\text { Shell's } \\
\text { Premium } \\
\text { Albian } \\
\text { Synthetic } \\
\text { (PAS) } \\
\end{array}$ & $\begin{array}{c}\text { Shell } \\
\text { Synthetic } \\
\text { Light } \\
\text { (SSX) }\end{array}$ & $\begin{array}{c}\text { Shell's } \\
\text { Albian } \\
\text { Heavy } \\
\text { Synthetic } \\
\text { (AHS) } \\
\end{array}$ & $\begin{array}{c}\text { Syncrude } \\
\text { Sweet } \\
\text { Premium } \\
\text { (SSP) }\end{array}$ \\
\hline Technology & $\mathrm{DC}$ & $\mathrm{DC}$ & $\mathrm{DC}$ & $\mathrm{DC}$ & $\mathrm{DC}$ & $\mathrm{HC}$ & $\mathrm{HC}$ & $\mathrm{HC}$ & $\mathrm{HC} / \mathrm{FC}$ \\
\hline Density, $\mathrm{kg} / \mathrm{m}^{3}$ & 862.0 & $799-870^{32,44}$ & 937.6 & $927.9^{3}$ & $909.1^{3}$ & 867.9 & 861.6 & 937.0 & 863.2 \\
\hline API Gravity, ${ }^{\circ}$ API & 32.5 & $31-45^{32,44}$ & 19.3 & $20.8^{3}$ & $23.9^{3}$ & 31.4 & 32.6 & 19.4 & 32.3 \\
\hline Sulfur, wt $\%$ & 0.18 & $<0.0015^{32,44}$ & 3.1 & $3.4^{3}$ & NA & 0.06 & 0.1 & 2.5 & 0.18 \\
\hline Nitrogen, mass ppm & 685.4 & $6-7$ & $1,353.5$ & NA & NA & 78.4 & 500.8 & $4,575.2$ & 671.0 \\
\hline
\end{tabular}

ULSD: ultra-low sulfur diesel, DC: delayed coking-based upgrading; HC: hydroconversion-based upgrading; HC/FC: combined hydroconversion and fluid coking-based upgrading 


\section{Methods: Description of Low and High Scenarios}

Low Scenarios. In the low scenarios, the values of the input parameters defining the energy requirements of the upgrader increase or decrease (with respect to the base scenarios values) to increase the efficiency of the upgrader and decrease the GHG intensity of the fuels consumed. The values of the energy use factors determining the energy consumption of each process unit are decreased, informed by the lower bounds of values found in literature. The fractions of fuel gas production used to substitute for natural gas are increased to reasonable values (fuel gas use avoids upstream natural gas GHG emissions). These values are informed by the $90^{\text {th }}$ percentile of data of fuel gas used by oil sands operators reported to $\mathrm{AER}^{45}$ after their latest known modification to their upgrading operations to the end of 2016. For DC and $\mathrm{HC} / \mathrm{FC}$, the fractions of coke production used as fuel are decreased and values informed by the $10^{\text {th }}$ percentile

of AER's data ${ }^{45}$ of coke usage in recent years since their latest known improvement of operations. Finally, in the low scenarios all electricity is supplied by cogeneration, since cogenerated electricity has a lower GHG intensity than that from the Alberta grid.

High Scenarios. OSTUM 2.0's input parameters describing the energy requirements of the upgrader in the high GHG scenarios adopt increased or decreased values with respect to the base scenario ones in order to simulate a less efficient operation using more GHG-intensive fuels. In this way, the value of most of OSTUM 2.0's energy use factors for the different process units are increased, informed by the upper bound of literature values. Energy use factors for which an increase of value would result in 
inconsistencies retain their base scenario values. For example, the energy use factors of the hydroprocessing units depend on their hydrogen consumption rates; since hydrogen consumption is constant throughout all scenarios, the base scenario energy use factors of all hydroprocessing units are also retained in high/low scenarios. On the other hand, the fractions of fuel gas production used are decreased, informed by the $10^{\text {th }}$ percentile of fuel gas use data reported to AER's ST39 ${ }^{45}$ by oil sands operators, for the period of time after their latest known modification to upgrading operations until the end of 2016. The fractions of coke production used as fuel are increased, informed by the $90^{\text {th }}$ percentile of historical coke use data for the same period of time. In the case of $\mathrm{HC} / \mathrm{FC}$, the coke consumption rate of Syncrude's fluid coker is constant throughout the years; therefore, coke consumption is not varied in this technology. A fraction of the electricity used is imported from the grid, informed by the $10^{\text {th }}$ percentile of data on use of cogenerated electricity for the aforementioned time period. The rest of the model's input parameters and assumptions conserve their base scenario values. 


\section{Methods: Delayed Coking Based Upgrading Low and High Scenarios Input Parameters and Assumptions}

Table S7. Input parameters for delayed coking based upgrading low and high scenarios with increased or decreased values with respect to the base scenario.

\begin{tabular}{|c|c|c|c|c|}
\hline \multicolumn{2}{|c|}{ Input Parameters } & $\begin{array}{r}\text { Base } \\
\text { Scenario } \\
\text { Value }\end{array}$ & $\begin{array}{r}\text { Low } \\
\text { Scenario } \\
\text { Value }\end{array}$ & $\begin{array}{r}\text { High } \\
\text { Scenario } \\
\text { Value }\end{array}$ \\
\hline \multicolumn{5}{|c|}{ Electricity Supply } \\
\hline & Fraction of Electricity Cogenerated ${ }^{\star}$ & $100 \%$ & $100 \%$ & $52 \%$ \\
\hline \multicolumn{5}{|c|}{ Disposition of By-products } \\
\hline & Fraction of Fuel Gas Used as Fuel ${ }^{*}$ & $64 \%$ & $71 \%$ & $54 \%$ \\
\hline & Fraction of Fuel Gas Used as SMR Feedstock* & $0 \%$ & $5 \%$ & $0 \%$ \\
\hline & Fraction of Coke Used as Fuel ${ }^{*}$ & $15 \%$ & $8 \%$ & $28 \%$ \\
\hline \multicolumn{5}{|c|}{ Energy Use Factors of Process Units } \\
\hline \multirow[t]{3}{*}{ DRU } & Natural gas use, scf/bbl feed & 88.0 & $53.9^{15}$ & $107.7^{22}$ \\
\hline & Electricity use, $\mathrm{kWh} / \mathrm{bbl}$ feed & 0.7 & $0.5^{2<}$ & $0.9^{15}$ \\
\hline & Steam use, lb/bbl feed & 17.5 & $10.0^{15}$ & $25.0^{<2}$ \\
\hline \multirow[t]{3}{*}{ VDU } & Natural gas use, scf/bbl feed & 79.0 & $32.3^{15}$ & $107.7^{22}$ \\
\hline & Electricity use, $\mathrm{kWh} / \mathrm{bbl}$ feed & 0.4 & $0.3^{15}$ & $0.5^{34}$ \\
\hline & Steam use, lb/bbl feed & 30.0 & $10.0^{15}$ & $50.0^{2<}$ \\
\hline \multirow[t]{3}{*}{ DCU } & Natural gas use, scf/bbl feed & 145.2 & $129.2^{2<}$ & $155.6^{2 \prime}$ \\
\hline & Electricity use, $\mathrm{kWh} / \mathrm{bbl}$ feed & 2.2 & $1.2^{2 \prime}$ & $3.6^{2<}$ \\
\hline & Steam use, $\mathrm{lb} / \mathrm{bbl}$ feed & 41.0 & $40.0^{2<}$ & $45.9^{15}$ \\
\hline \multirow[t]{3}{*}{ Naphtha HT } & Natural gas use, scf/ton feed & 874.7 & $874.7^{15}$ & $874.7^{15}$ \\
\hline & Electricity use, $\mathrm{kWh} /$ ton feed & 16.3 & $16.3^{15}$ & $16.3^{15}$ \\
\hline & Steam use, lb/bbl feed & 6.0 & $6.0^{15}$ & $6.0^{15}$ \\
\hline \multirow[t]{3}{*}{ LGO HT } & Natural gas use, scf/ton feed & $1,143.1$ & $1,143.1^{15}$ & $1,143.1^{15}$ \\
\hline & Electricity use, $\mathrm{kWh} /$ ton feed & 21.3 & $21.3^{15}$ & $21.3^{15}$ \\
\hline & Steam use, lb/bbl feed & 8.0 & $8.0^{15}$ & $8.0^{15}$ \\
\hline \multirow[t]{3}{*}{ HGO HT } & Natural gas use, scf/ton feed & $1,387.2$ & $1,387.2^{15}$ & $1,387.2^{15}$ \\
\hline & Electricity use, $\mathrm{kWh} /$ ton feed & 38.6 & $38.6^{15}$ & $38.6^{15}$ \\
\hline & Steam use, lb/bbl feed & 10.0 & $10.0^{15}$ & $10.0^{15}$ \\
\hline \multirow[t]{2}{*}{ AT/AR } & Electricity use, $\mathrm{kWh} /$ ton feed & 21.7 & $13.0^{21}$ & $31.2^{38}$ \\
\hline & Steam use, lb/ton feed & 822.2 & $822.2^{<\prime}$ & $1,891.2^{3 y}$ \\
\hline \multirow[t]{4}{*}{ SRU } & $S$ recovery - natural gas use, scf/ton $S$ prod & 204.2 & $204.2^{35}$ & $204.2^{35}$ \\
\hline & $\mathrm{S}$ recovery - electricity use, $\mathrm{kWh} /$ ton $\mathrm{S}$ prod & 65.8 & $40.0^{22}$ & $98.0^{15}$ \\
\hline & TG treatment - natural gas use, scf/ton S prod & 816.7 & $816.7^{35}$ & $816.7^{35}$ \\
\hline & TG treatment - electricity use, $\mathrm{kWh} /$ ton S prod & 245.5 & $28.0^{35}$ & $463.0^{21}$ \\
\hline \multirow[t]{4}{*}{ SMR } & Natural gas use as fuel, scf/scf H prod & 0.04 & $0.02^{46}$ & $0.12^{4 \prime}$ \\
\hline & Natural gas use as feedstock, scf/scf H prod & 0.34 & $0.31^{4 /}$ & $0.38^{48}$ \\
\hline & Steam use, Ib/scf H prod & 0.05 & $0.05^{40}$ & $0.05^{40}$ \\
\hline & Electricity use, kWh/scf H prod & 0.0007 & $0.0005^{46}$ & $0.002^{4 y}$ \\
\hline \multirow[t]{2}{*}{ BLRS } & Fuel use, $\mathrm{MJ} / \mathrm{kg}$ steam prod & 3.3 & $3.3^{2 \prime}$ & $3.3^{21}$ \\
\hline & Electricity use, $\mathrm{kWh} / \mathrm{kg}$ steam prod & 0.005 & $0.005^{<1}$ & $0.005^{<1}$ \\
\hline \multirow[t]{3}{*}{ COGEN } & Efficiency of gas turbine, $\%$ & 30.0 & $40.0^{41}$ & $20.0^{41}$ \\
\hline & $\begin{array}{l}\text { Efficiency of heat recovery steam generator - } \\
\text { recovery of exhaust heat from gas turbine, \% }\end{array}$ & 50.0 & $55.0^{41}$ & $45.0^{41}$ \\
\hline & $\begin{array}{l}\text { Efficiency of heat recovery steam generator - } \\
\text { using supplemental firing, \% }\end{array}$ & 95.0 & $95.0^{41}$ & $88.0^{42}$ \\
\hline
\end{tabular}

Notes: Only the input parameters with increased/decreased values with respect to the base scenario are shown; rest of parameters conserve their base scenario values. Values of hydrotreaters retain their base scenario values in all scenarios since hydrogen consumption does not change and no other literature source was found reporting sets of lower/higher energy use factors that are consistent for the three hydrotreaters. * Indicates increased/decreased values with respect to base scenario that are informed by the $90^{\text {th }}$ percentile $/ 10^{\text {th }}$ percentile, respectively, of data reported to AER by Suncor after the latest known modification to their 
upgrading operations (2008) to the end of 2016. Abbreviations: DRU: diluent recovery unit; VDU: vacuum distillation unit; DCU: delayed coker unit; Naphtha HT: naphtha hydrotreater unit; LGO HT: light gas oil hydrotreater unit; HGO HT: heavy gas oil hydrotreater unit; AT/AR: amine treatment/amine regeneration units; SRU: sulfur recovery unit; SMR: steam methane reformer; BLRS: boilers; COGEN: cogeneration unit; S: sulfur; TG: tail gas; H: hydrogen; prod: produced. 


\section{Methods: Hydroconversion Based Upgrading Low and High Scenarios Input Parameters and Assumptions}

Table S8. Input parameters for hydroconversion based upgrading low and high scenarios with increased or decreased values with respect to the base scenario.

\begin{tabular}{|c|c|c|c|c|}
\hline \multicolumn{2}{|c|}{ Input Parameters } & $\begin{array}{r}\text { Base } \\
\text { Scenario } \\
\text { Value }\end{array}$ & $\begin{array}{r}\text { Low } \\
\text { Scenario } \\
\text { Value }\end{array}$ & $\begin{array}{r}\text { High } \\
\text { Scenario } \\
\text { Value }\end{array}$ \\
\hline \multicolumn{5}{|c|}{ Electricity Supply } \\
\hline & Fraction of Electricity Cogenerated ${ }^{*}$ & $90 \%$ & $100 \%$ & $62 \%$ \\
\hline & Fraction of Electricity from Grid* & $10 \%$ & $0 \%$ & $38 \%$ \\
\hline \multicolumn{5}{|c|}{ Disposition of By-products } \\
\hline & Fraction of Fuel Gas Used as Fuel ${ }^{\star}$ & $59 \%$ & $45 \%$ & $60 \%$ \\
\hline & Fraction of Fuel Gas Used as SMR Feedstock ${ }^{*}$ & $41 \%$ & $55 \%$ & $13 \%$ \\
\hline \multicolumn{5}{|c|}{ Energy Use Factors of Process Units } \\
\hline \multirow[t]{3}{*}{ DRU } & Natural gas use, scf/bbl feed & 88.0 & $53.9^{15}$ & $107.7^{22}$ \\
\hline & Electricity use, $\mathrm{kWh} / \mathrm{bbl}$ feed & 0.7 & $0.5^{2<}$ & $0.9^{15}$ \\
\hline & Steam use, $\mathrm{lb} / \mathrm{bbl}$ feed & 17.5 & $10.0^{15}$ & $25.0^{2<}$ \\
\hline \multirow[t]{3}{*}{ VDU } & Natural gas use, scf/bbl feed & 79.0 & $32.3^{15}$ & $107.7^{22}$ \\
\hline & Electricity use, $\mathrm{kWh} / \mathrm{bbl}$ feed & 0.4 & $0.3^{15}$ & $0.5^{34}$ \\
\hline & Steam use, $\mathrm{lb} / \mathrm{bbl}$ feed & 30.0 & $10.0^{15}$ & $50.0^{2<}$ \\
\hline \multirow[t]{3}{*}{$\mathrm{HCU}$} & Natural gas use, scf/bbl feed & 125.9 & $125.9^{<<}$ & $125.9^{<<}$ \\
\hline & Electricity use, $\mathrm{kWh} / \mathrm{bbl}$ feed & 16.5 & $16.5^{43}$ & $16.5^{43}$ \\
\hline & Steam use, lb/ton feed & 149.9 & $149.9^{21}$ & $149.9^{21}$ \\
\hline \multirow[t]{3}{*}{ Naphtha HT } & Natural gas use, scf/ton feed & 844.0 & $844.0^{15}$ & $844.0^{15}$ \\
\hline & Electricity use, $\mathrm{kWh} / \mathrm{ton}$ feed & 15.7 & $15.7^{15}$ & $15.7^{15}$ \\
\hline & Steam use, $\mathrm{lb} / \mathrm{bbl}$ feed & 5.8 & $5.8^{15}$ & $5.8^{15}$ \\
\hline \multirow[t]{3}{*}{ LGO HT } & Natural gas use, scf/ton feed & $1,063.8$ & $1,063.8^{15}$ & $1,063.8^{15}$ \\
\hline & Electricity use, kWh/ton feed & 19.8 & $19.8^{15}$ & $19.8^{15}$ \\
\hline & Steam use, lb/bbl feed & 7.4 & $7.4^{15}$ & $7.4^{15}$ \\
\hline \multirow[t]{3}{*}{ HGO HT } & Natural gas use, scf/ton feed & $1,361.0$ & $1,361.0^{15}$ & $1,361.0^{15}$ \\
\hline & Electricity use, $\mathrm{kWh} /$ ton feed & 37.9 & $37.9^{15}$ & $37.9^{15}$ \\
\hline & Steam use, lb/bbl feed & 9.8 & $9.8^{15}$ & $9.8^{15}$ \\
\hline \multirow[t]{2}{*}{ AT/AR } & Electricity use, $\mathrm{kWh} /$ ton feed & 21.7 & $13.0^{2 \prime}$ & $31.2^{38}$ \\
\hline & Steam use, lb/ton feed & 822.2 & $822.2^{2 \prime}$ & $1,891.2^{3 y}$ \\
\hline \multirow[t]{4}{*}{ SRU } & S recovery - natural gas use, scf/ton S prod & 204.2 & $204.2^{35}$ & $204.2^{35}$ \\
\hline & $\mathrm{S}$ recovery - electricity use, $\mathrm{kWh} /$ ton $\mathrm{S}$ prod & 65.8 & $40.0^{2<2}$ & $98.0^{15}$ \\
\hline & TG treatment - natural gas use, scf/ton S prod & 816.7 & $816.7^{35}$ & $816.7^{35}$ \\
\hline & TG treatment - electricity use, $\mathrm{kWh} /$ ton $\mathrm{S}$ prod & 245.5 & $28.0^{35}$ & $463.0^{<1}$ \\
\hline \multirow[t]{4}{*}{ SMR } & Natural gas use as fuel, scf/scf $\mathrm{H}$ prod & 0.04 & $0.02^{46}$ & $0.12^{4 /}$ \\
\hline & Natural gas use as feedstock, scf/scf $\mathrm{H}$ prod & 0.34 & $0.31^{4 !}$ & $0.38^{48}$ \\
\hline & Steam use, lb/scf H prod & 0.05 & $0.05^{40}$ & $0.05^{40}$ \\
\hline & Electricity use, $\mathrm{kWh} / \mathrm{scf} \mathrm{H}$ prod & 0.0007 & $0.0005^{46}$ & $0.002^{4 y}$ \\
\hline \multirow[t]{2}{*}{ BLRS } & Fuel use, MJ/kg steam prod & 3.3 & $3.3^{2 \prime}$ & $3.3^{21}$ \\
\hline & Electricity use, $\mathrm{kWh} / \mathrm{kg}$ steam prod & 0.005 & $0.005^{21}$ & $0.005^{21}$ \\
\hline \multirow[t]{3}{*}{ COGEN } & Efficiency of gas turbine, \% & 30.0 & $40.0^{41}$ & $20.0^{41}$ \\
\hline & $\begin{array}{l}\text { Efficiency of heat recovery steam generator - } \\
\text { recovery of exhaust heat from gas turbine, \% }\end{array}$ & 50.0 & $55.0^{41}$ & $45.0^{41}$ \\
\hline & $\begin{array}{l}\text { Efficiency of heat recovery steam generator - } \\
\text { using supplemental firing, \% }\end{array}$ & 95.0 & $95.0^{41}$ & $88.0^{42}$ \\
\hline
\end{tabular}

Notes: Only the input parameters with increased/decreased values with respect to the base scenario are shown; rest of parameters conserve their base scenario values. Values of hydrocracker and hydrotreaters retain their base scenario values in all scenarios since hydrogen consumption does not change and no other literature source was found reporting sets of lower/higher energy use factors that are consistent for the three hydrotreaters. * Indicates increased/decreased values with respect to base scenario that are informed by the $90^{\text {th }}$ percentile $/ 10^{\text {th }}$ percentile, respectively, of data reported to AER by Shell after the latest known 
modification to their upgrading operations (2011) to the end of 2016. Abbreviations: DRU: diluent recovery unit; VDU: vacuum distillation unit; HCU: hydroconverter unit; Naphtha HT: naphtha hydrotreater unit; LGO HT: light gas oil hydrotreater unit; HGO HT: heavy gas oil hydrotreater unit; AT/AR: amine treatment/amine regeneration units; SRU: sulfur recovery unit; SMR: steam methane reformer; BLRS: boilers; COGEN: cogeneration unit; S: sulfur; TG: tail gas; $\mathrm{H}$ : hydrogen; prod: produced. 


\section{Methods: Combined Hydroconversion and Fluid Coking Based Upgrading Low and High Scenarios Input Parameters and Assumptions}

Table S9. Input parameters for combined hydroconversion and fluid coking based upgrading low and high scenarios with increased/decreased values with respect to the base scenario.

\begin{tabular}{|c|c|c|c|c|}
\hline \multicolumn{2}{|c|}{ Input Parameters } & $\begin{array}{r}\text { Base } \\
\text { Scenario } \\
\text { Value }\end{array}$ & $\begin{array}{r}\text { Low } \\
\text { Scenario } \\
\text { Value }\end{array}$ & $\begin{array}{r}\text { High } \\
\text { Scenario } \\
\text { Value }\end{array}$ \\
\hline \multicolumn{5}{|c|}{ Electricity Supply } \\
\hline & Fraction of Electricity Cogenerated ${ }^{*}$ & $72 \%$ & $79 \%$ & $67 \%$ \\
\hline & Fraction of Electricity from Grid ${ }^{\star}$ & $28 \%$ & $21 \%$ & $33 \%$ \\
\hline \multicolumn{5}{|c|}{ Disposition of By-products } \\
\hline & Fraction of Fuel Gas Used as Fuel ${ }^{*}$ & $100 \%$ & $100 \%$ & $93 \%$ \\
\hline & Fraction of Fuel Gas Used as SMR Feedstock* & $0 \%$ & $0 \%$ & $0 \%$ \\
\hline & Fraction of Coke Used as Fuel ${ }^{*}$ & $21 \%$ & $21 \%$ & $21 \%$ \\
\hline \multicolumn{5}{|c|}{ Energy Use Factors of Process Units } \\
\hline \multirow[t]{3}{*}{ DRU } & Natural gas use, scf/bbl feed & 88.0 & $53.9^{15}$ & $107.7^{22}$ \\
\hline & Electricity use, $\mathrm{kWh} / \mathrm{bbl}$ feed & 0.7 & $0.5^{2<}$ & $0.9^{15}$ \\
\hline & Steam use, lb/bbl feed & 17.5 & $10.0^{15}$ & $25.0^{22}$ \\
\hline \multirow[t]{3}{*}{ VDU } & Natural gas use, scf/bbl feed & 79.0 & $32.3^{15}$ & $107.7^{2<}$ \\
\hline & Electricity use, $\mathrm{kWh} / \mathrm{bbl}$ feed & 0.4 & $0.3^{15}$ & $0.5^{34}$ \\
\hline & Steam use, lb/bbl feed & 30.0 & $10.0^{15}$ & $50.0^{22}$ \\
\hline \multirow[t]{3}{*}{ HCU } & Natural gas use, scf/bbl feed & 85.0 & $85.0^{22}$ & $85.0^{22}$ \\
\hline & Electricity use, $\mathrm{kWh} / \mathrm{bbl}$ feed & 13.9 & $13.9^{43}$ & $13.9^{43}$ \\
\hline & Steam use, lb/bbl feed & 149.9 & $149.9^{2 \prime}$ & $149.9^{2 \prime}$ \\
\hline \multirow[t]{3}{*}{ FCU } & Coke use, wt\% coke produced ${ }^{*}$ & 21.0 & $21.0^{45}$ & $21.0^{45}$ \\
\hline & Electricity use, $\mathrm{kWh} / \mathrm{bbl}$ feed & 30.0 & $13.0^{22}$ & $30.0^{43}$ \\
\hline & Steam use, lb/bbl feed & 100.0 & $25.0^{43}$ & $100.0^{2<}$ \\
\hline \multirow[t]{3}{*}{ Naphtha HT } & Natural gas use, scf/ton feed & 874.7 & $874.7^{15}$ & $874.7^{15}$ \\
\hline & Electricity use, $\mathrm{kWh} /$ ton feed & 16.3 & $16.3^{15}$ & $16.3^{15}$ \\
\hline & Steam use, lb/bbl feed & 6.0 & $6.0^{15}$ & $6.0^{15}$ \\
\hline \multirow[t]{3}{*}{ LGO HT } & Natural gas use, scf/ton feed & $1,143.1$ & $1,143.1^{15}$ & $1,143.1^{15}$ \\
\hline & Electricity use, $\mathrm{kWh} /$ ton feed & 21.3 & $21.3^{10}$ & $21.3^{15}$ \\
\hline & Steam use, lb/bbl feed & 8.0 & $8.0^{15}$ & $8.0^{15}$ \\
\hline \multirow[t]{3}{*}{ HGO HT } & Natural gas use, scf/ton feed & $1,387.2$ & $1,387.2^{15}$ & $1,387.2^{15}$ \\
\hline & Electricity use, $\mathrm{kWh} /$ ton feed & 38.6 & $38.6^{15}$ & $38.6^{15}$ \\
\hline & Steam use, lb/bbl feed & 10.0 & $10.0^{15}$ & $10.0^{15}$ \\
\hline \multirow[t]{2}{*}{ AT/AR } & Electricity use, $\mathrm{kWh} /$ ton feed & 21.7 & $13.0^{2 \prime}$ & $31.2^{38}$ \\
\hline & Steam use, lb/ton feed & 822.2 & $822.2^{2 \prime}$ & $1,891.2^{3 y}$ \\
\hline \multirow[t]{4}{*}{ SRU } & S recovery - natural gas use, scf/ton S prod & 204.2 & $204.2^{35}$ & $204.2^{35}$ \\
\hline & $\mathrm{S}$ recovery - electricity use, $\mathrm{kWh} /$ ton S prod & 65.8 & $40.0^{2<}$ & $98.0^{15}$ \\
\hline & TG treatment - natural gas use, scf/ton S prod & 816.7 & $816.7^{35}$ & $816.7^{35}$ \\
\hline & TG treatment - electricity use, $\mathrm{kWh} /$ ton $\mathrm{S}$ prod & 245.5 & $28.0^{35}$ & $463.0^{21}$ \\
\hline \multirow[t]{4}{*}{ SMR } & Natural gas use as fuel, scf/scf H prod & 0.04 & $0.02^{46}$ & $0.12^{4 \prime}$ \\
\hline & Natural gas use as feedstock, scf/scf $\mathrm{H}$ prod & 0.34 & $0.31^{4 \prime}$ & $0.38^{48}$ \\
\hline & Steam use, Ib/scf H prod & 0.05 & $0.05^{40}$ & $0.05^{40}$ \\
\hline & Electricity use, kWh/scf H prod & 0.0007 & $0.0005^{46}$ & $0.002^{4 y}$ \\
\hline \multirow[t]{2}{*}{ BLRS } & Fuel use, $\mathrm{MJ} / \mathrm{kg}$ steam prod & 3.3 & $3.3^{21}$ & $3.3^{2 \prime}$ \\
\hline & Electricity use, $\mathrm{kWh} / \mathrm{kg}$ steam prod & 0.005 & $0.005^{2 \prime}$ & $0.005^{21}$ \\
\hline \multirow[t]{3}{*}{ COGEN } & Efficiency of gas turbine, $\%$ & 30.0 & $40.0^{41}$ & $20.0^{41}$ \\
\hline & $\begin{array}{l}\text { Efficiency of heat recovery steam generator - } \\
\text { recovery of exhaust heat from gas turbine, \% }\end{array}$ & 50.0 & $55.0^{41}$ & $45.0^{41}$ \\
\hline & $\begin{array}{l}\text { Efficiency of heat recovery steam generator - } \\
\text { using supplemental firing, \% }\end{array}$ & 95.0 & $95.0^{41}$ & $88.0^{42}$ \\
\hline
\end{tabular}

Notes: Only the input parameters with increased/decreased values with respect to the base scenario are shown; rest of parameters conserve their base scenario values. Values of hydrocracker and hydrotreaters retain their base scenario values in all scenarios since hydrogen consumption does not change and no other literature source was found reporting 
sets of lower/higher energy use factors that are consistent for the three hydrotreaters. * Indicates increased/decreased values with respect to base scenario that are informed by the $90^{\text {th }}$ percentile $/ 10^{\text {th }}$ percentile, respectively, of data reported to AER by Syncrude after the latest known modification to their upgrading operations (2007) to the end of 2016. Abbreviations: DRU: diluent recovery unit; VDU: vacuum distillation unit; HCU: hydroconverter unit; FCU: fluid coker unit; Naphtha HT: naphtha hydrotreater unit; LGO HT: light gas oil hydrotreater unit; HGO HT: heavy gas oil hydrotreater unit; AT/AR: amine treatment/amine regeneration units; SRU: sulfur recovery unit; SMR: steam methane reformer; BLRS: boilers; COGEN: cogeneration unit; S: sulfur; TG: tail gas; $\mathrm{H}$ : hydrogen; prod: produced. 


\section{Methods: Sensitivity Analysis for Delayed Coking Based Upgrading}

Table S10. Description of the variation of different energy inputs in delayed coking based upgrading's sensitivity analysis.

\begin{tabular}{|c|c|c|c|c|c|}
\hline \multicolumn{6}{|c|}{ Energy Inputs Varied in Sensitivity Analysis } \\
\hline & $\begin{array}{l}\text { "Fraction of Coke } \\
\text { Production Used" }\end{array}$ & $\begin{array}{l}\text { "Fraction of Fuel Gas } \\
\text { Production Used" }\end{array}$ & $\begin{array}{l}\text { “Upgrader's Fuel } \\
\text { Requirements" }\end{array}$ & $\begin{array}{l}\text { "Upgrader's Steam } \\
\text { Requirements" }\end{array}$ & $\begin{array}{c}\text { “Upgrader's Electricity } \\
\text { Requirements” }\end{array}$ \\
\hline $\begin{array}{l}\text { Parameter(s) } \\
\text { of Interest } \\
\text { Deviating } \\
\text { from BS }\end{array}$ & $\begin{array}{l}\text { Variation in the amount of } \\
\text { coke used as fuel in } \\
\text { boilers. In this case, } \\
\text { less/more coke used } \\
\text { means more/less of other } \\
\text { fuels (i.e., fuel gas and/or } \\
\text { natural gas) is used in } \\
\text { boilers to satisfy constant } \\
\text { steam requirements. }\end{array}$ & $\begin{array}{l}\text { Variation in the amount of } \\
\text { fuel gas used as fuel in } \\
\text { process heaters, in boilers } \\
\text { for steam production, and } \\
\text { as feedstock for hydrogen } \\
\text { production. In this case, } \\
\text { less/more fuel gas used } \\
\text { means more/less natural } \\
\text { gas is used to satisfy } \\
\text { constant } \\
\text { heat/steam/hydrogen } \\
\text { requirements. }\end{array}$ & $\begin{array}{l}\text { Variation in the fuel } \\
\text { requirements (natural } \\
\text { gas/fuel gas) of all PUs, } \\
\text { all at once. Less/more fuel } \\
\text { requirements in the PUs } \\
\text { may be the result of an } \\
\text { increase/decrease in the } \\
\text { upgrader's } \\
\text { efficiency. }\end{array}$ & $\begin{array}{l}\text { Variation in the steam } \\
\text { requirements of all PUs, } \\
\text { all at once. Less/more } \\
\text { steam requirements in the } \\
\text { PUs may be the result of } \\
\text { an increase/decrease in } \\
\text { the upgrader's energy } \\
\text { efficiency. }\end{array}$ & $\begin{array}{l}\text { Variation in the electricity } \\
\text { requirements of all PUs, } \\
\text { all at once. Less/more } \\
\text { electricity requirements in } \\
\text { PUs may be the result of } \\
\text { an increase/decrease in } \\
\text { the plant's energy } \\
\text { efficiency. }\end{array}$ \\
\hline $\begin{array}{l}\text { Value of } \\
\text { Parameter(s) } \\
\text { of Interest in } \\
\text { BS }\end{array}$ & $\begin{array}{l}\text { In BS, } 15 \% \text { of coke } \\
\text { production is used in } \\
\text { boilers; other input } \\
\text { parameters/assumptions } \\
\text { as in Table S3. }\end{array}$ & $\begin{array}{l}\text { In BS, 64\% of fuel gas } \\
\text { production is used in } \\
\text { process heaters and } \\
\text { boilers; other input } \\
\text { parameters / assumptions } \\
\text { as in Table S3. }\end{array}$ & $\begin{array}{l}\text { Fuel requirements per unit } \\
\text { of feed (scf/bbl feed, } \\
\text { scf/ton feed) for each PU } \\
\text { are presented in Table S3. }\end{array}$ & $\begin{array}{l}\text { Steam requirements per } \\
\text { unit of feed (lb/bbl feed) } \\
\text { for each PU are presented } \\
\text { in Table S3. }\end{array}$ & $\begin{array}{l}\text { Electricity requirements } \\
\text { per unit of feed (kWh/bbl } \\
\text { feed, kWh/ton feed) for } \\
\text { each PU are presented in } \\
\text { Table S3. }\end{array}$ \\
\hline $\begin{array}{l}\text { Value of } \\
\text { Parameter(s) } \\
\text { of Interest in } \\
\text { Sensitivity } \\
\text { Analysis }\end{array}$ & 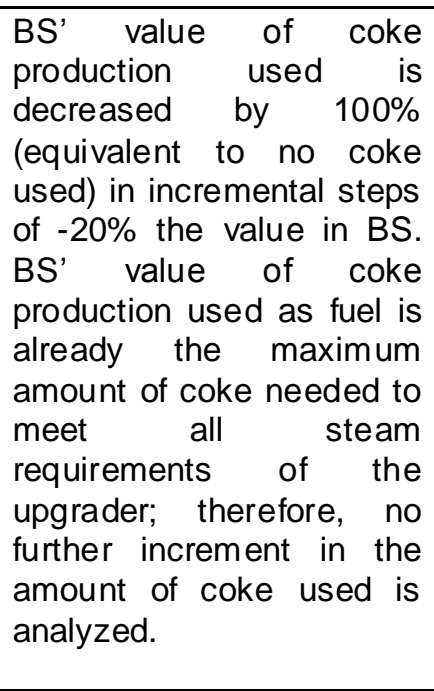 & $\begin{array}{l}\text { BS' value of fuel gas } \\
\text { production used is } \\
\text { decreased by } 100 \% \\
\text { (equivalent to no fuel gas } \\
\text { used) and increased by a } \\
\text { maximum } 60 \% \text { increment } \\
\text { of the BS' value } \\
\text { (equivalent to use } 100 \% \\
\text { of the fuel gas production) } \\
\text { in incremental steps of } \\
\pm 20 \% \text { the value in BS. }\end{array}$ & $\begin{array}{l}\text { BS' values of the fuel } \\
\text { requirements of all PUs } \\
\text { are decreased all at once } \\
\text { to a minimum of } 40 \% \text { of } \\
\text { the values in the BS. } \\
\text { Likewise, BS' } \\
\text { requirements } \\
\text { increased all at once to a } \\
\text { maximum } 20 \% \text { increment, } \\
\text { in incremental steps of } \\
\pm 20 \% \text { the values in BS. } \\
\text { The decrease/increase in } \\
\text { BS' values reflects the } \\
\text { ranges of fuel } \\
\text { requirements found in the } \\
\text { literature for each PU. }\end{array}$ & $\begin{array}{l}\text { BS' values of the steam } \\
\text { requirements of all PUs } \\
\text { are decreased all at once } \\
\text { to a minimum of } 40 \% \text { of } \\
\text { the values in the BS, in } \\
\text { incremental steps of - } \\
20 \% \text {. Likewise, BS' steam } \\
\text { requirements are } \\
\text { increased all at once to a } \\
\text { maximum } 40 \% \text { increment, } \\
\text { in incremental steps of } \\
+20 \% \text { the values in BS. } \\
\text { The decrease/increase in } \\
\text { BS' values reflects the } \\
\text { ranges of steam } \\
\text { requirements found in the } \\
\text { literature for each PU. }\end{array}$ & $\begin{array}{l}\text { BS' values of the } \\
\text { electricity requirements of } \\
\text { all PUs are decreased all } \\
\text { at once to a minimum of } \\
40 \% \text { of the values in the } \\
\text { BS, and increased all at } \\
\text { once to a maximum } 40 \% \\
\text { increment of the values in } \\
\text { BS, in incremental steps } \\
\text { of } \pm 20 \% \text {. } \\
\text { decrease/increase in BS' } \\
\text { values reflects the ranges } \\
\text { of electricity requirements } \\
\text { found in the literature for } \\
\text { each PU. }\end{array}$ \\
\hline
\end{tabular}

PU: process unit; BS: base scenario. 


\section{Methods: Sensitivity Analysis for Hydroconversion Based Upgrading}

Table S11. Description of the variation of different types of energy inputs in hydroconversion based upgrading's sensitivity analysis.

\begin{tabular}{|c|c|c|c|c|}
\hline \multicolumn{5}{|c|}{ Energy Inputs Varied in Sensitivity Analysis } \\
\hline & $\begin{array}{l}\text { "Fraction of Fuel Gas } \\
\text { Production Used" }\end{array}$ & $\begin{array}{l}\text { “Upgrader's Fuel } \\
\text { Requirements" }\end{array}$ & $\begin{array}{l}\text { "Upgrader's Steam } \\
\text { Requirements" }\end{array}$ & $\begin{array}{l}\text { "Upgrader's Electricity } \\
\text { Requirements" }\end{array}$ \\
\hline $\begin{array}{l}\text { Parameter(s) } \\
\text { of Interest } \\
\text { Deviating } \\
\text { from BS }\end{array}$ & $\begin{array}{l}\text { Variation in the amount of fuel } \\
\text { gas used as fuel in process } \\
\text { heaters, in boilers for steam } \\
\text { production, and as feedstock for } \\
\text { hydrogen production. In this } \\
\text { case, less/more fuel gas used } \\
\text { means more/less natural gas is } \\
\text { used to satisfy constant } \\
\text { heat/steam/hydrogen } \\
\text { requirements. }\end{array}$ & $\begin{array}{l}\text { Variation in the fuel requirements } \\
\text { (natural gas/fuel gas) of all PUs, } \\
\text { all at once. Less/more fuel } \\
\text { requirements in the PUs may be } \\
\text { the result of an } \\
\text { increase/decrease in the } \\
\text { upgrader's energy efficiency. }\end{array}$ & $\begin{array}{l}\text { Variation in the steam } \\
\text { requirements of all PUs, all at } \\
\text { once. Less/more steam } \\
\text { requirements in the PUs may be } \\
\text { the result of in the } \\
\text { increase/decrease an } \\
\text { upgrader's energy efficiency. }\end{array}$ & $\begin{array}{l}\text { Variation in the electricity } \\
\text { requirements of all PUs, all at } \\
\text { once. Less/more electricity } \\
\text { requirements in PUs may be the } \\
\text { result of an increase/decrease in } \\
\text { the plant's energy efficiency. }\end{array}$ \\
\hline $\begin{array}{l}\text { Value of } \\
\text { Parameter(s) } \\
\text { of Interest in } \\
\text { BS }\end{array}$ & $\begin{array}{l}\text { In BS, } 100 \% \text { of fuel gas } \\
\text { production is used in process } \\
\text { heaters, boilers, and as } \\
\text { feedstock for hydrogen } \\
\text { production; other input } \\
\text { parameters / assumptions as in } \\
\text { Table S4. }\end{array}$ & $\begin{array}{l}\text { Fuel requirements per unit of } \\
\text { feed (scf/bbl feed, scf/ton feed) } \\
\text { for each PU are presented in } \\
\text { Table S4. }\end{array}$ & $\begin{array}{l}\text { Steam requirements per unit of } \\
\text { feed }(\mathrm{lb} / \mathrm{bbl} \text { feed) for each } \mathrm{PU} \text { are } \\
\text { presented in Table S4. }\end{array}$ & $\begin{array}{l}\text { Electricity requirements per unit } \\
\text { of feed ( } \mathrm{kWh} / \mathrm{bbl} \text { feed, } \mathrm{kWh} / \text { ton } \\
\text { feed) for each PU are presented } \\
\text { in Table S4. }\end{array}$ \\
\hline $\begin{array}{l}\text { Value of } \\
\text { Parameter(s) } \\
\text { of Interest in } \\
\text { Sensitivity } \\
\text { Analysis }\end{array}$ & $\begin{array}{l}\text { BS' value of fuel gas production } \\
\text { used is decreased by } 100 \% \\
\text { (equivalent to no fuel gas used) } \\
\text { in incremental steps of }-20 \% \text { the } \\
\text { value in BS. No further increment } \\
\text { of the BS' value is tested, since } \\
\text { the BS already uses all fuel gas } \\
\text { available. }\end{array}$ & $\begin{array}{l}\text { BS' values of the fuel } \\
\text { requirements of all PUs are } \\
\text { decreased all at once to a } \\
\text { minimum of } 40 \% \text { of the values in } \\
\text { the BS, and increased all at once } \\
\text { to a maximum } 20 \% \text { increment of } \\
\text { the values in BS, in incremental } \\
\text { steps of } \pm 20 \% \text {. The } \\
\text { decrease/increase in BS' values } \\
\text { reflects the ranges of fuel } \\
\text { requirements found in the } \\
\text { literature for each PU. }\end{array}$ & $\begin{array}{l}\text { BS' values of the steam } \\
\text { requirements of all PUs are } \\
\text { decreased all at once to a } \\
\text { minimum of } 40 \% \text { of the values in } \\
\text { the BS, and increased all at once } \\
\text { to a maximum } 40 \% \text { increment of } \\
\text { the values in BS, in incremental } \\
\text { steps of } \pm 20 \% \text {. The } \\
\text { decrease/increase in BS' values } \\
\text { reflects the ranges of steam } \\
\text { requirements found in the } \\
\text { literature for each PU. }\end{array}$ & $\begin{array}{l}\text { BS' values of the electricity } \\
\text { requirements of all PUs are } \\
\text { decreased all at once to a } \\
\text { minimum of } 40 \% \text { of the values in } \\
\text { the BS, and increased all at once } \\
\text { to a maximum } 40 \% \text { increment of } \\
\text { the values in BS, in incremental } \\
\text { steps of } \pm 20 \% \text {. The } \\
\text { decrease/increase in BS' values } \\
\text { reflects the ranges of electricity } \\
\text { requirements found in the } \\
\text { literature for each PU. }\end{array}$ \\
\hline
\end{tabular}

PU: process unit; BS: base scenario. 


\section{Methods: Sensitivity Analysis for Combined Hydroconversion and Fluid Coking Based Upgrading}

Table S12. Description of the variation of different types of energy inputs in combined hydroconversion and fluid coking based upgrading's sensitivity analysis.

\begin{tabular}{|c|c|c|c|c|c|}
\hline \multicolumn{6}{|c|}{ Energy Inputs Varied in Sensitivity Analysis } \\
\hline & $\begin{array}{l}\text { "Fraction of Coke } \\
\text { Production Used" }\end{array}$ & $\begin{array}{l}\text { "Fraction of Fuel Gas } \\
\text { Production Used" }\end{array}$ & $\begin{array}{l}\text { “Upgrader's Fuel } \\
\text { Requirements" }\end{array}$ & $\begin{array}{l}\text { "Upgrader's Steam } \\
\text { Requirements" }\end{array}$ & $\begin{array}{l}\text { "Upgrader's Electricity } \\
\text { Requirements" }\end{array}$ \\
\hline $\begin{array}{l}\text { Parameter(s) } \\
\text { of Interest } \\
\text { Deviating } \\
\text { from BS }\end{array}$ & $\begin{array}{l}\text { Variation in the amount of } \\
\text { coke used as fuel in the } \\
\text { fluid coker. In this case, } \\
\text { less/more coke used in } \\
\text { the fluid coker means the } \\
\text { furnace technology's } \\
\text { efficiency } \\
\text { increases/decreases, as } \\
\text { does the amount of fuel } \\
\text { requirement to produce a } \\
\text { desired reaction } \\
\text { temperature. No coke is } \\
\text { used in boilers. }\end{array}$ & $\begin{array}{l}\text { Variation in the amount of } \\
\text { fuel gas used as fuel in } \\
\text { process heaters and } \\
\text { boilers for steam } \\
\text { production. In this case, } \\
\text { less/more fuel gas used } \\
\text { means more/less natural } \\
\text { gas is used to satisfy } \\
\text { constant } \\
\text { heat/steam/hydrogen } \\
\text { requirements. }\end{array}$ & $\begin{array}{l}\text { Variation in the fuel } \\
\text { (natural gas/fuel gas) } \\
\text { requirements of all PUs, } \\
\text { all at once. Less/more fuel } \\
\text { requirements in the PUs } \\
\text { may be the result of an } \\
\text { increase/decrease in the } \\
\text { upgrader's } \\
\text { efficiency. }\end{array}$ & $\begin{array}{l}\text { Variation in the steam } \\
\text { requirements of all ]PUs, } \\
\text { all at once. Less/more } \\
\text { steam requirements in the } \\
\text { PUs may be the result of } \\
\text { an increase/decrease in } \\
\text { the upgrader's energy } \\
\text { efficiency. }\end{array}$ & $\begin{array}{l}\text { Variation in the electricity } \\
\text { requirements of all PUs, } \\
\text { all at once. Less electricity } \\
\text { requirements in PUs may } \\
\text { also be the result of an } \\
\text { increase in the plant's } \\
\text { energy efficiency. }\end{array}$ \\
\hline
\end{tabular}

\begin{tabular}{|c|c|c|c|c|c|}
\hline $\begin{array}{l}\text { Value of } \\
\text { Parameter(s) } \\
\text { of Interest in } \\
\text { BS }\end{array}$ & $\begin{array}{l}\text { In BS, } 21 \% \text { of coke } \\
\text { production is used as fuel } \\
\text { in the fluid coker; other } \\
\text { input } \\
\text { parameters/assumptions } \\
\text { as in Table S5. }\end{array}$ & $\begin{array}{l}\text { In BS, } 100 \% \text { of fuel gas } \\
\text { production is used in } \\
\text { process heaters and } \\
\text { boilers; other input } \\
\text { parameters / assumptions } \\
\text { as in Table S5. }\end{array}$ & $\begin{array}{l}\text { Fuel requirements per unit } \\
\text { of feed (scf/bbl feed, } \\
\text { scf/ton feed) for each PU } \\
\text { are presented in Table S5. }\end{array}$ & $\begin{array}{l}\text { Steam requirements per } \\
\text { unit of feed (lb/bbl feed) } \\
\text { for each major PU are } \\
\text { presented in Table S5. }\end{array}$ & $\begin{array}{l}\text { Electricity requirements } \\
\text { per unit of feed (kWh/bbl } \\
\text { feed, kWh/ton feed) for } \\
\text { each PU are presented in } \\
\text { Table S5. }\end{array}$ \\
\hline $\begin{array}{l}\text { Value of } \\
\text { Parameter(s) } \\
\text { of Interest in } \\
\text { Sensitivity } \\
\text { Analysis }\end{array}$ & $\begin{array}{l}\text { BS' value of coke } \\
\text { production used is } \\
\text { decreased by } 40 \% \\
\text { (equivalent to } 13 \% \text { of coke } \\
\text { production used) and } \\
\text { increased by a maximum } \\
20 \% \text { increment of the BS } \\
\text { value (equivalent to } 25 \% \\
\text { of coke production used), } \\
\text { in incremental steps of } \\
\pm 20 \% \text {. This range of coke } \\
\text { production use in the fluid } \\
\text { coker is informed by the } \\
\text { literature. }\end{array}$ & $\begin{array}{l}\text { BS' value of fuel gas } \\
\text { production used is } \\
\text { decreased by } 100 \% \\
\text { (equivalent to no fuel gas } \\
\text { used) in incremental steps } \\
\text { of - } 20 \% \text { the value in BS. } \\
\text { No further increment of } \\
\text { BS's value is tested, since } \\
\text { the BS already uses all } \\
\text { fuel gas available. }\end{array}$ & $\begin{array}{l}\text { BS' values of fuel } \\
\text { requirements of all PUs } \\
\text { are decreased all at once } \\
\text { to a minimum of } 40 \% \text { of } \\
\text { the values in the BS, and } \\
\text { increased all at once to a } \\
\text { maximum } 20 \% \text { increment } \\
\text { of the values in BS, in } \\
\text { incremental steps of } \\
\pm 20 \% \text {. The } \\
\text { decrease/increase in BS } \\
\text { values reflects the ranges } \\
\text { of fuel requirements found } \\
\text { in the literature for each } \\
\text { PU. }\end{array}$ & $\begin{array}{l}\text { BS' values of the steam } \\
\text { requirements of all PUs } \\
\text { are decreased all at once } \\
\text { to a minimum of } 40 \% \text { of } \\
\text { the values in the BS, and } \\
\text { increased all at once to a } \\
\text { maximum } 40 \% \text { increment } \\
\text { of the values in BS, in } \\
\text { incremental steps of } \\
\pm 20 \% \text {. The } \\
\text { decrease/increase in BS' } \\
\text { values reflects the ranges } \\
\text { of steam requirements } \\
\text { found in the literature for } \\
\text { each PU. }\end{array}$ & $\begin{array}{l}\text { BS' values of the } \\
\text { electricity requirements of } \\
\text { all PUs are decreased all } \\
\text { at once to a minimum of } \\
40 \% \text { of the values in the } \\
\text { BS, and increased all at } \\
\text { once to a maximum } 40 \% \\
\text { increment of the values in } \\
\text { BS, in incremental steps } \\
\text { of } \pm 20 \% \text {. } \\
\text { decrease/increase in BS' } \\
\text { values reflects the ranges } \\
\text { of electricity requirements } \\
\text { found in the literature for } \\
\text { each PU. }\end{array}$ \\
\hline
\end{tabular}

PU: process unit; BS: base scenario. 


\section{Methods: Procedure to Fill in Gaps of Missing AER ST39 Data}

AER's ST3945 online publication reports oil sands production, supplies, dispositions, and inventory of oil sands and processing products, like SCO, for a given month and the preceding months of the year. The data are collected from monthly submissions to AER by oil sands operators in Alberta in a cumulative monthly view.

For the present study, ST39 ${ }^{45}$ annual reports for the time period $1983-2016$ were consulted to obtain monthly data on SCO production and associated energy use from Suncor, Shell, and Syncrude's upgrading operations. The data used in this analysis are: volume of bitumen further processed or upgraded ( $\left.\mathrm{m}^{3} / \mathrm{month}\right)$, volume of SCO production ( $\mathrm{m}^{3} /$ month), volume of natural gas used in plant and as fuel ( $\mathrm{m}^{3} /$ month), volume of natural gas further processed or used as feedstock for hydrogen production ( $\mathrm{m}^{3} /$ month), volume of process gas (fuel gas) produced $\left(\mathrm{m}^{3} /\right.$ month), volume of process gas (fuel gas) used in plant and as fuel $\left(\mathrm{m}^{3} / \mathrm{month}\right.$ ), volume of process gas (fuel gas) further processed or used as feedstock for hydrogen production $\left(\mathrm{m}^{3} /\right.$ month), amount of coke produced (tonnes/month), amount of coke used as fuel (tonnes/month), electricity use (MWh/month), electricity purchased ( $\mathrm{MWh} /$ month), and electricity generated (MWh/month).

For each of the oil sands operators' database there are periods of time where data is not available. Blank spaces on the original AER reports are the most common sources of data unavailability. In order to avoid effects of the missing 
data on the conclusions drawn on this study from the data set (e.g., introduce bias or affect the representativeness of the results), the regression imputation technique is used to fill in the missing data. That is, instead of deleting/not taking into account the periods of time for which data is not available, the missing data is replaced with probable values estimated using other available information. A polynomial regression of known monthly data is performed to estimate a $3^{\text {rd }}$ degree polynomial model (the Excel model best fitting the known historical data) that approximates values of each type of energy use data as a function of monthly SCO production values. The values of monthly SCO production are known for all the time period of interest, except the years of 1999 and 2004. Fitted values from the regression model are used to impute the missing data. After all missing values have been replaced by this approach, the data set is analyzed using basic statistics (minimum, maximum, median, $10^{\text {th }}$ and $90^{\text {th }}$ percentiles).

The aforementioned approach was chosen for its straightforwardness and its advantage of significantly avoiding the alteration of the standard deviation or the shape of the distribution. ${ }^{50}$ However, a problem of this technique is that the imputed data do not have an error term/uncertainty included in their estimation and thus the estimates fit perfectly along the regression curve. The most likely values of the missing data are predicted by the regression model, suggesting a greater correlation between the relationships than is warranted. ${ }^{50}$ 


\section{Results: Detailed Results for the Base Scenarios of All Upgrading Technologies Evaluated}

Table S13. Product/by-product yields, product properties, energy use, and direct and indirect GHG intensities for DC, HC, and HC/FC.

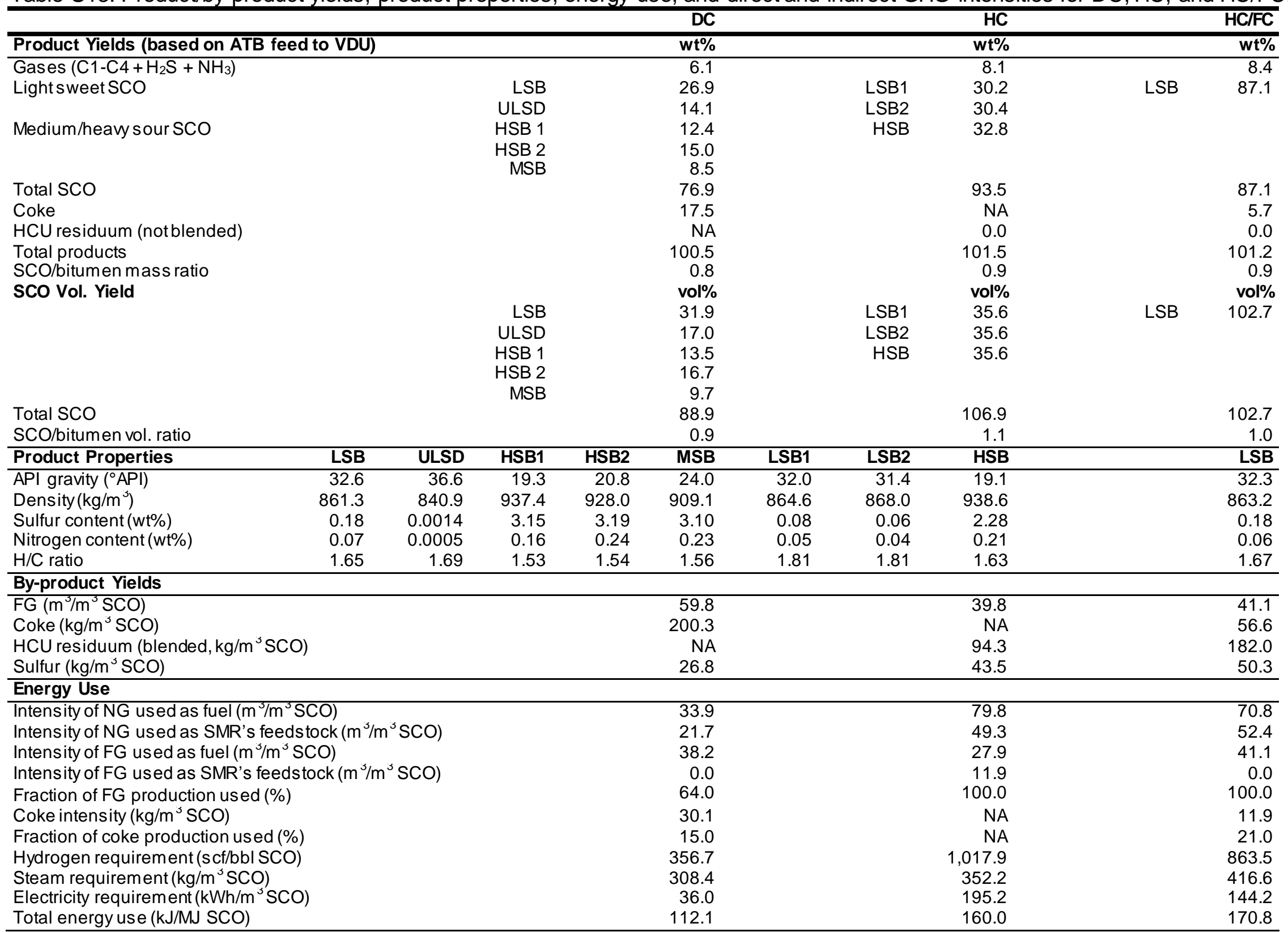




\begin{tabular}{|c|c|c|c|c|c|c|c|c|c|c|c|c|}
\hline \multicolumn{13}{|c|}{ Breakdown of GHG Intensities ( $\mathrm{g} \mathrm{CO}_{2} \mathrm{e} / \mathrm{MJ}$ product) } \\
\hline & & LSB & ULSD & HSB1 & HSB2 & MSB & Total SCO & LSB1 & LSB2 & HSB & Total SCO & Total SCO \\
\hline \multirow{6}{*}{$\begin{array}{l}\text { Emissions } \\
\text { in } \\
\text { upgrading } \\
\text { processes } \\
\text { and in } \\
\text { utilities }\end{array}$} & $\begin{array}{l}\mathrm{NG} / \mathrm{FG} / \text { coke used in heaters } \\
\text { of upgrading processes }{ }^{2}\end{array}$ & 5.0 & 5.2 & 1.8 & 2.8 & 3.0 & 3.9 & 4.5 & 4.5 & 2.0 & 3.6 & 4.8 \\
\hline & $\begin{array}{l}\mathrm{NG} / \mathrm{FG} / \text { coke used in boilers } \\
\text { for steam production }\end{array}$ & 2.6 & 3.0 & 1.3 & 2.2 & 2.3 & 2.3 & 0.8 & 0.8 & 0.4 & 0.7 & 1.6 \\
\hline & $\begin{array}{l}\mathrm{NG} / \mathrm{FG} \text { used in hydrogen } \\
\text { production }\end{array}$ & 2.7 & 2.5 & 0.4 & 0.0 & 0.0 & 1.5 & 5.0 & 5.0 & 2.4 & 4.1 & 3.6 \\
\hline & NG used in cogeneration & 0.4 & 0.5 & 0.2 & 0.4 & 0.5 & 0.4 & 2.1 & 2.1 & 1.4 & 1.9 & 1.2 \\
\hline & Electricity from grid & 0.0 & 0.0 & 0.0 & 0.0 & 0.0 & 0.0 & 0.5 & 0.5 & 0.1 & 0.4 & 0.8 \\
\hline & Fugitives/venting/flaring & 0.3 & 0.4 & 0.3 & 0.4 & 0.4 & 0.4 & 0.1 & 0.1 & 0.1 & 0.1 & 0.2 \\
\hline \multirow{5}{*}{$\begin{array}{l}\text { Emissions } \\
\text { by type of } \\
\text { fuel }\end{array}$} & $\begin{array}{l}\text { NG used in upgrading } \\
\text { processes + utilities }\end{array}$ & 4.8 & 4.9 & 1.5 & 1.9 & 2.0 & 3.4 & 9.4 & 9.4 & 5.1 & 7.9 & 7.7 \\
\hline & $\begin{array}{l}\text { FG used in upgrading } \\
\text { processes + utilities }\end{array}$ & 3.3 & 3.3 & 1.0 & 1.4 & 1.5 & 2.4 & 3.0 & 3.0 & 1.1 & 2.4 & 2.6 \\
\hline & $\begin{array}{l}\text { Coke used in upgrading } \\
\text { processes + utilities }\end{array}$ & 2.5 & 2.9 & 1.3 & 2.2 & 2.3 & 2.3 & NA & NA & NA & NA & 0.9 \\
\hline & Electricity from grid & 0.0 & 0.0 & 0.0 & 0.0 & 0.0 & 0.0 & 0.5 & 0.5 & 0.1 & 0.4 & 0.8 \\
\hline & Fugitives/venting/flaring & 0.3 & 0.4 & 0.3 & 0.4 & 0.4 & 0.4 & 0.1 & 0.1 & 0.1 & 0.1 & 0.2 \\
\hline \multirow{15}{*}{$\begin{array}{l}\text { Emissions } \\
\text { by } \\
\text { process } \\
\text { unit }\end{array}$} & DRU & 1.5 & 1.7 & 0.7 & 1.3 & 1.4 & 1.3 & 1.4 & 1.4 & 0.8 & 1.2 & 1.3 \\
\hline & VDU & 1.0 & 1.1 & 0.5 & 0.8 & 0.9 & 0.9 & 0.9 & 0.9 & 0.5 & 0.7 & 0.6 \\
\hline & DCU & 0.8 & 0.9 & 0.4 & 0.7 & 0.8 & 0.8 & NA & NA & NA & NA & NA \\
\hline & $\mathrm{HCU}$ & NA & NA & NA & NA & NA & NA & 0.7 & 0.7 & 0.5 & 0.6 & 0.6 \\
\hline & FCU & NA & NA & NA & NA & NA & NA & NA & NA & NA & NA & 1.3 \\
\hline & N HT & 0.1 & 0.0 & 0.1 & 0.0 & 0.0 & 0.1 & 0.2 & 0.1 & 0.1 & 0.1 & 0.2 \\
\hline & LGO HT & 0.3 & 1.5 & 0.04 & 0.0 & 0.0 & 0.4 & 0.4 & 0.7 & 0.2 & 0.4 & 0.6 \\
\hline & HGO HT & 1.2 & 0.0 & 0.01 & 0.0 & 0.0 & 0.4 & 1.4 & 1.2 & 0.05 & 0.9 & 1.1 \\
\hline & AT/AR & 0.0 & 0.0 & 0.0 & 0.0 & 0.0 & 0.0 & 0.004 & 0.004 & 0.001 & 0.003 & 0.01 \\
\hline & SRU & 0.01 & 0.01 & 0.01 & 0.01 & 0.01 & 0.01 & 0.03 & 0.03 & 0.01 & 0.02 & 0.04 \\
\hline & SMR & 2.7 & 2.5 & 0.4 & 0.0 & 0.0 & 1.5 & 5.0 & 5.0 & 2.4 & 4.1 & 3.7 \\
\hline & Boilers & 2.6 & 3.0 & 1.3 & 2.2 & 2.3 & 2.3 & 0.8 & 0.8 & 0.4 & 0.7 & 1.6 \\
\hline & Cogeneration & 0.4 & 0.5 & 0.2 & 0.4 & 0.5 & 0.4 & 2.1 & 2.1 & 1.4 & 1.9 & 1.2 \\
\hline & Fugitives/venting/flaring & 0.3 & 0.4 & 0.3 & 0.4 & 0.4 & 0.4 & 0.1 & 0.1 & 0.1 & 0.1 & 0.2 \\
\hline & Total & 11.0 & 11.5 & 4.1 & 5.9 & 6.2 & 8.5 & 13.0 & 13.1 & 6.5 & 10.8 & 12.2 \\
\hline
\end{tabular}

DC: delayed coking based upgrading; HC: hydroconversion based upgrading; HC/FC: combined hydroconversion and fluid coking bas ed upgrading; ATB: atmospheric topped bitumen; VDU: vacuum distillation unit; $\mathrm{C} 1-\mathrm{C} 4$ : methane, ethane, propane and butane gases; $\mathrm{H}_{2} \mathrm{~S}$ : hydrogen sulphide; $\mathrm{NH}_{3}$ : ammonia; SCO: synthetic crude oil; LSB: light sweet SCO blend; ULSD: ultra-low sulfur diesel; HSB: heavy sour SCO blend; MSB: medium sour SCO blend; HCU: hydroconverter unit; vol.: volumetric; H/C: hydrogen to carbon ratio; FG: fuel gas; NA: not applicable; GHG: greenhouse gas; NG: natural gas; DRU: diluent recovery unit; DCU: delayed coker unit; FCU: fluid coker unit; N HT: naphtha hydrotreater unit; LGO HT: light gas oil hydrotreater unit; HGO HT: heavy gas oil hydrotreater unit; AT/AR: amine treatment/regeneration units; SRU: sulfur recovery unit; SMR: steam methane reformer. 


\section{Results: Detailed Results for Hydroconversion Based Upgrading Base Scenario 2}

Table S14. Product and by-product yields, product properties, energy use, direct and indirect GHG intensities for HC base scenario 2.

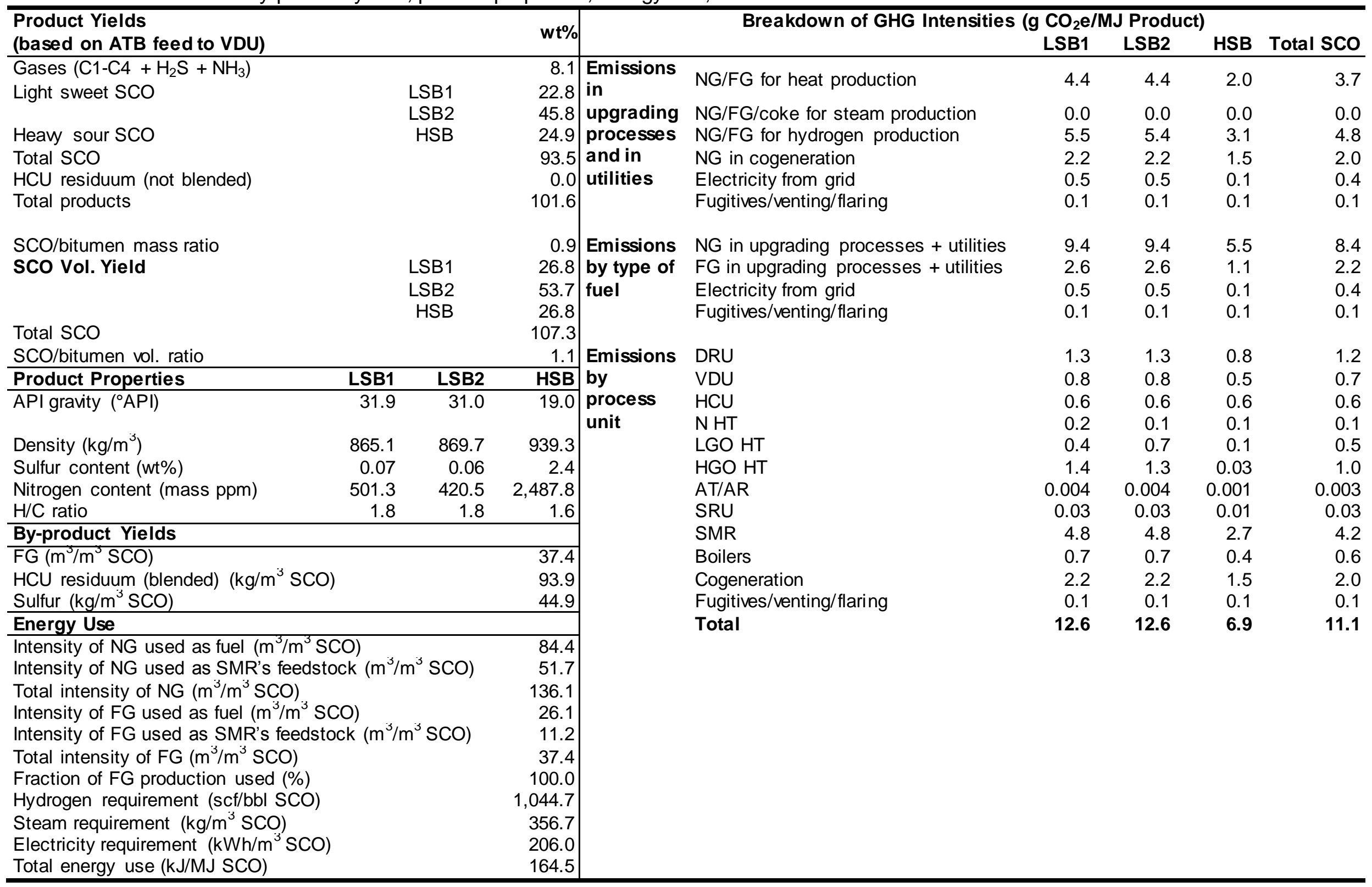


HC: hydroconversion based upgrading; ATB: atmospheric topped bitumen; VDU: vacuum distillation unit; C1-C4: methane, ethane, propane and butane gases; $\mathrm{H}_{2} \mathrm{~S}$ : hydrogen sulphide; $\mathrm{NH}_{3}$ : ammonia; SCO: synthetic crude oil; LSB: light sweet SCO blend; HSB: heavy sour SCO blend; HCU: hydroconverter unit; vol.: volumetric; H/C: hydrogen to carbon ratio; NG: natural gas; FG: fuel gas; GHG: greenhouse gas; DRU: diluent recovery unit; N HT: naphtha hydrotreater unit; LGO HT: light gas oil hydrotreater unit; HGO HT: heavy gas oil hydrotreater unit; AT/AR: amine treatment/regeneration units; SRU: sulfur recovery unit; SMR: steam methane reformer. 
Results: Base and Range of GHG Intensities of Hydroconversion Base Upgrading Base Scenario 2

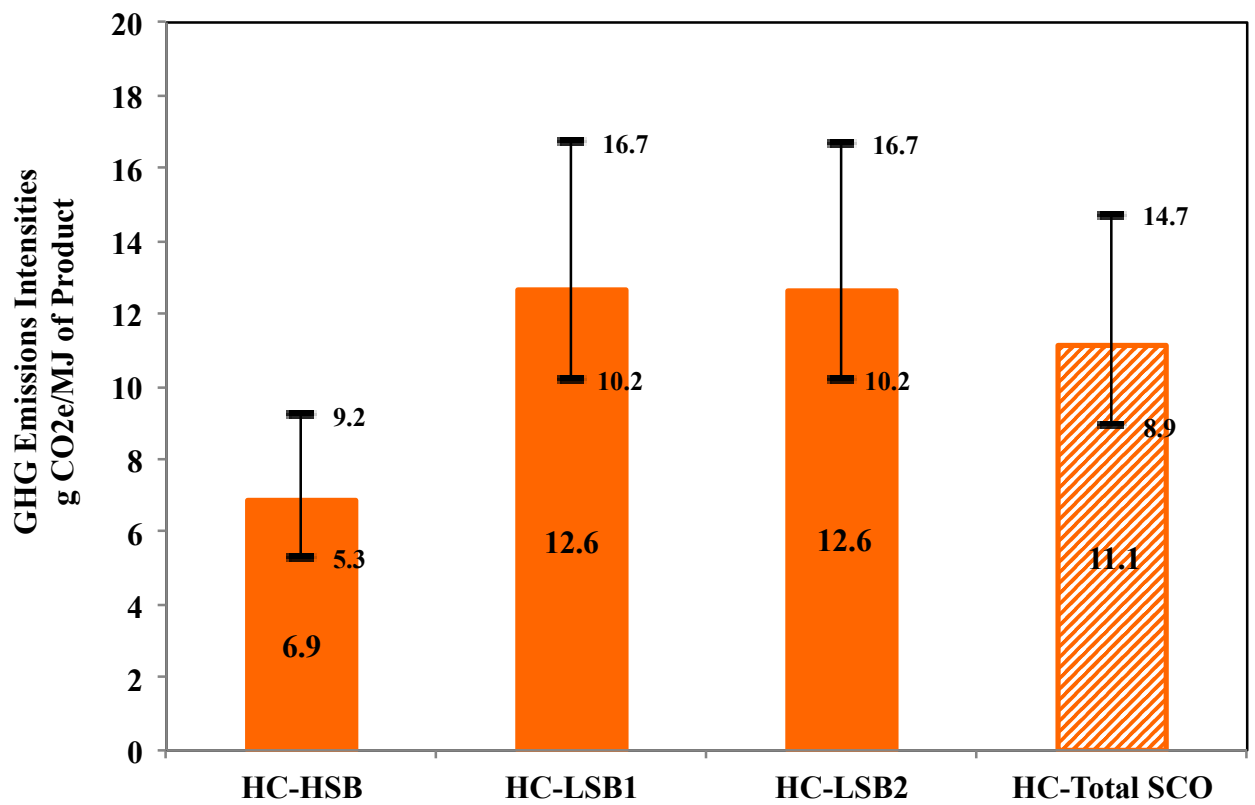

Figure S1. Base and range of GHG intensities of HC base scenario 2.

Notes: bars represent HC base scenario 2's base GHG intensities; high-low lines represent high and low scenarios' GHG intensities. Abbreviations: HC: hydroconversion based upgrading; HSB: heavy sour SCO blend; LSB: light sweet SCO blend; SCO: synthetic crude oil 


\section{Results: Low Scenarios Results}

Table S15. OSTUM 2.0's estimates of energy use and GHG intensities for DC, HC, and HC/FC low scenarios.

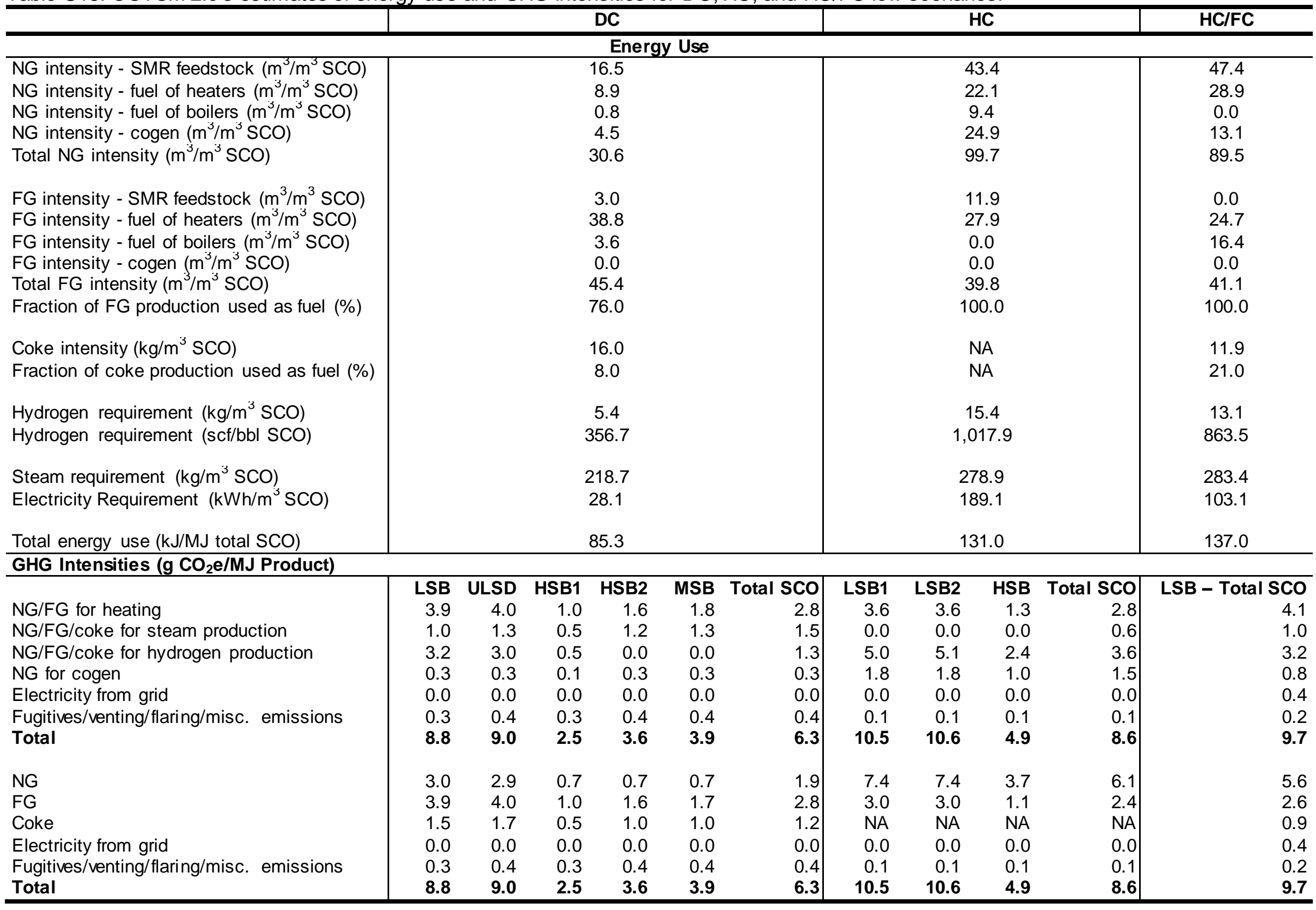




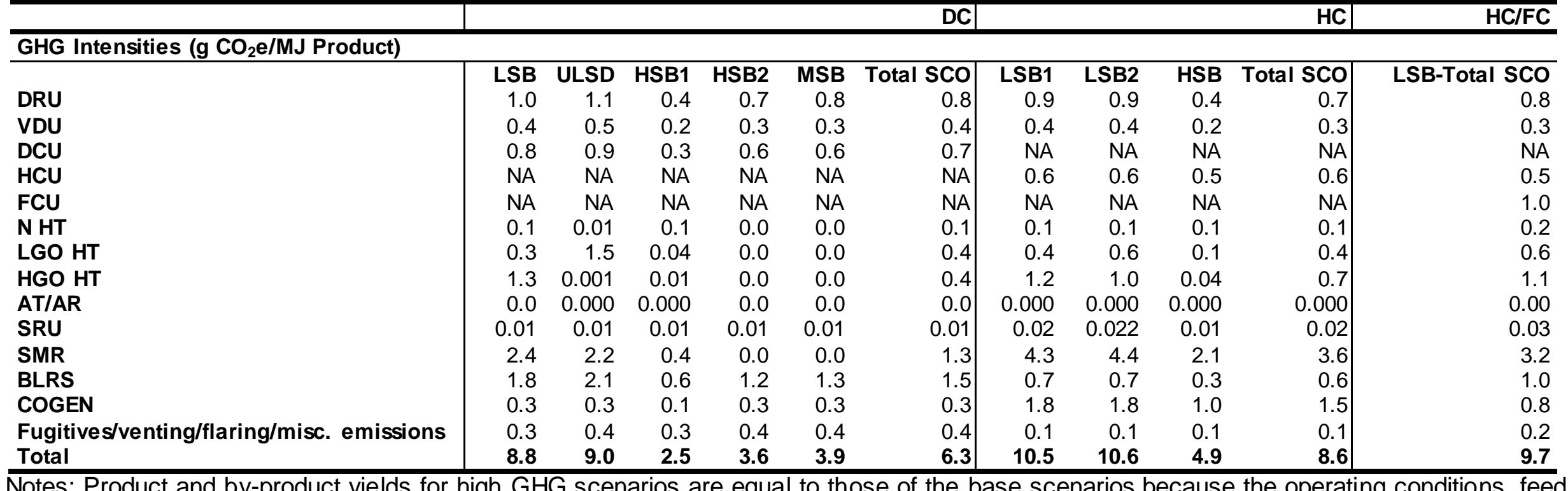

Notes: Product and by-product yields for high GHG scenarios are equal to those of the base scenarios because the operating conditions, feed and product quality assumptions remain unchanged and only the energy inputs required to achieve the same quality of products are varied. Abbreviations: DC: delayed coking based upgrading; HC: hydroconversion based upgrading; $\mathrm{HC} / \mathrm{FC}$ : combined hydroconversion and fluid coking based upgrading; GHG: greenhouse gas; NG: natural gas; FG: fuel gas; SCO: synthetic crude oil; LSB: light sweet SCO blend; ULSD: ultra-low sulfur diesel; HSB: heavy sour SCO blend; MSB: medium sour SCO blend; NA: not applicable; DRU: diluent recovery unit; VDU: vacuum distillation unit; DCU: delayed coke unit; HCU: hydroconverter unit; FCU: fluid coker unit; N HT: naphtha hydrotreater unit; LGO HT: light gas oil hydrotreater unit; HGO HT: heavy gas oil hydrotreater unit; AT/AR: amine treatment/regeneration units; SRU: sulfur recovery unit; SMR: steam methane reformer; cogen: cogeneration; BLRS: boilers; misc.: miscellaneous . 


\section{Results: High Scenarios Results}

Table S16. OSTUM 2.0's estimates of energy use and GHG intensities for DC, HC, and HC/FC high scenarios.

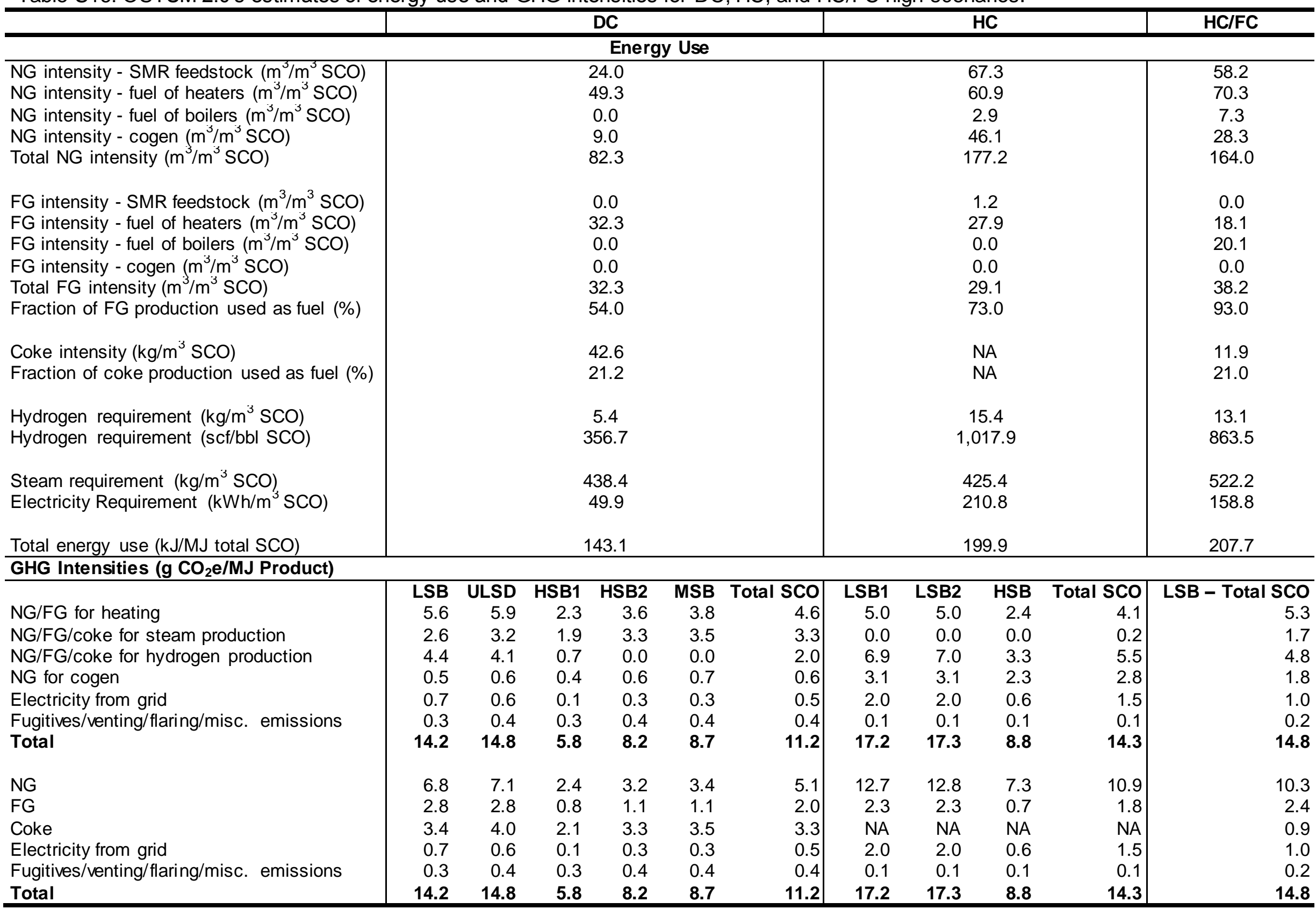




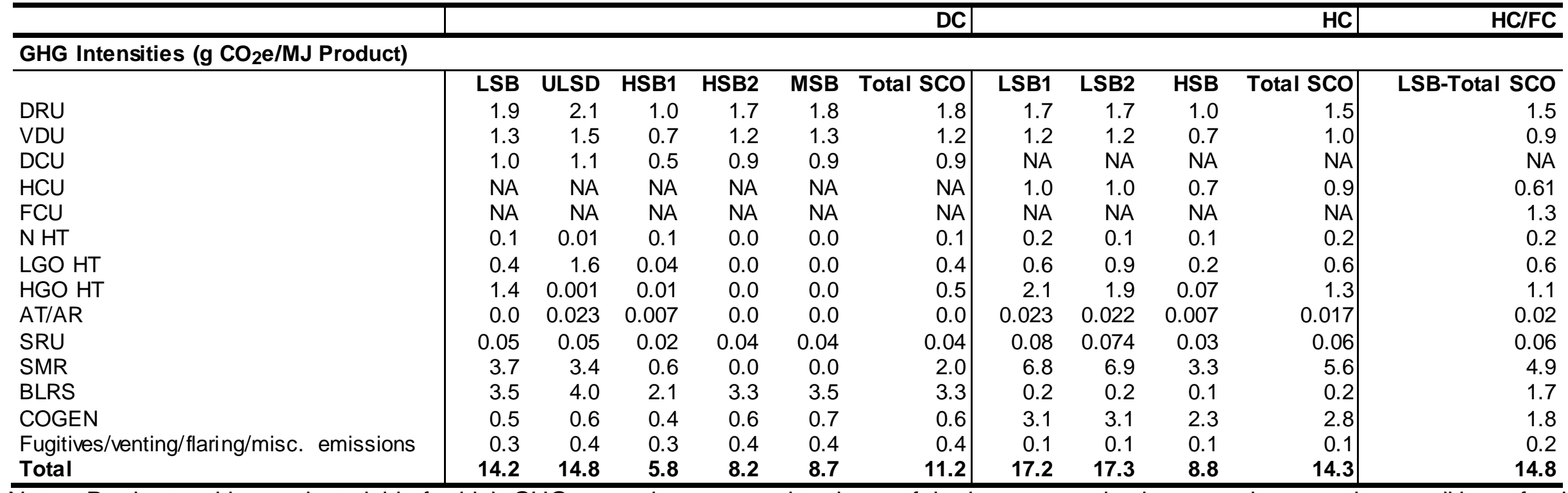

Notes: Product and by-product yields for high GHG scenarios are equal to those of the base scenarios because the operating conditions, feed and product quality assumptions remain unchanged and only the energy inputs required to achieve the same quality of products are varied. Abbreviations: DC: delayed coking based upgrading; $\mathrm{HC}$ : hydroconversion based upgrading; $\mathrm{HC} / \mathrm{FC}$ : combined hydroconversion and fluid coking based upgrading; GHG: greenhouse gas; NG: natural gas; FG: fuel gas; SCO: synthetic crude oil; LSB: light sweet SCO blend; ULSD: ultra-low sulfur diesel; HSB: heavy sour SCO blend; MSB: medium sour SCO blend; NA: not applicable; DRU: diluent recovery unit; VDU: vacuum distillation unit; DCU: delayed coke unit; HCU: hydroconverter unit; FCU: fluid coker unit; N HT: naphtha hydrotreater unit; LGO HT: light gas oil hydrotreater unit; HGO HT: heavy gas oil hydrotreater unit; AT/AR: amine treatment/regeneration units; SRU: sulfur recovery unit; SMR: steam methane reformer; cogen: cogeneration; BLRS: boilers; misc.: miscellaneous. 
Results: GHG Intensities Allocated to DC and HC's SCO Products Using Different Allocation Methods

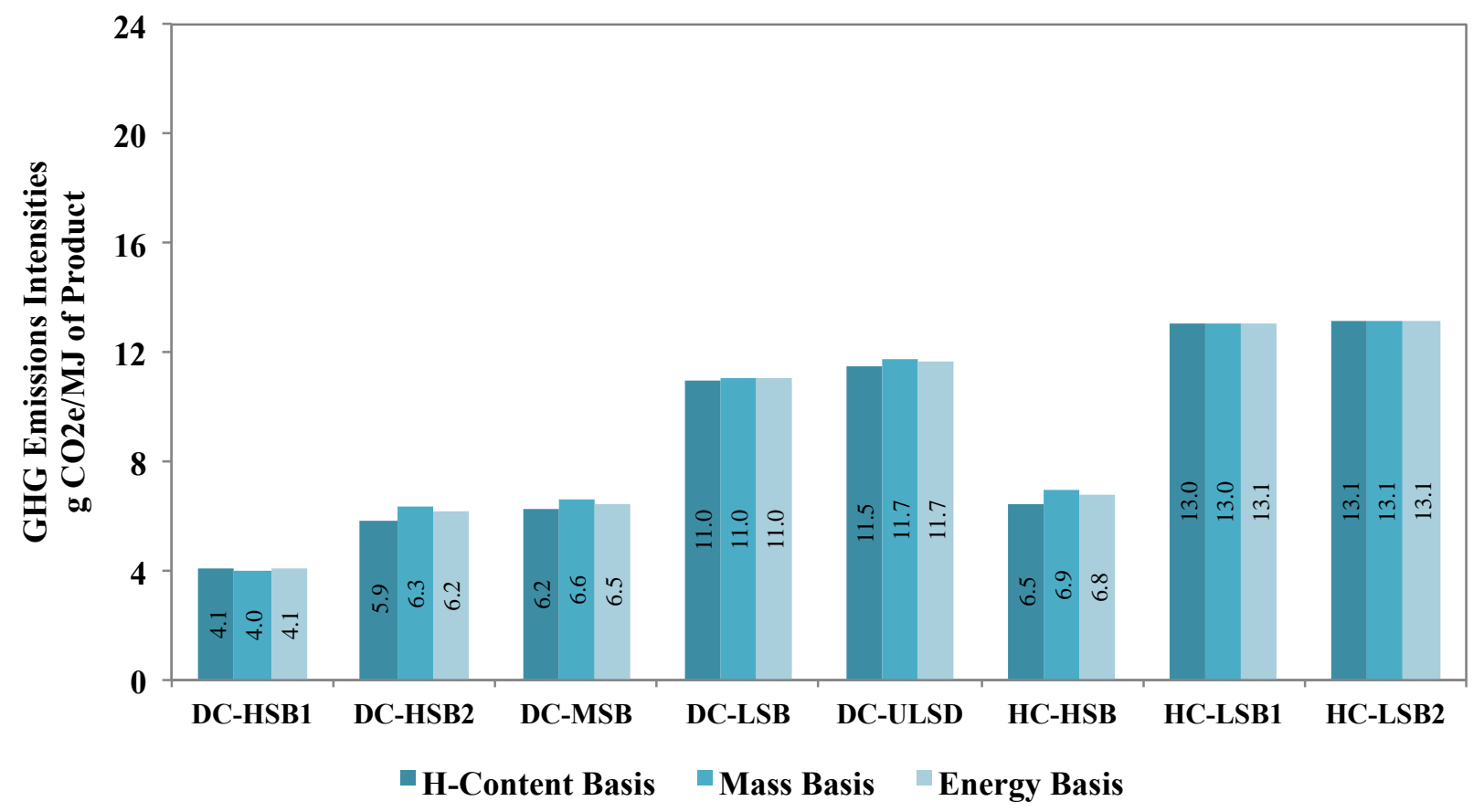

Figure S2. GHG intensities allocated to each SCO blend using the three allocation methods included in OSTUM 2.0.

Abbreviations: GHG: greenhouse gas; DC: delayed coking based upgrading; HC:

hydroconversion based upgrading; LSB: light sweet SCO blend; ULSD: ultra-low sulfur diesel; HSB: heavy sour SCO blend; MSB: medium sour SCO blend; H-Content: hydrogen content. 


\section{Results: Sensitivity Analysis}
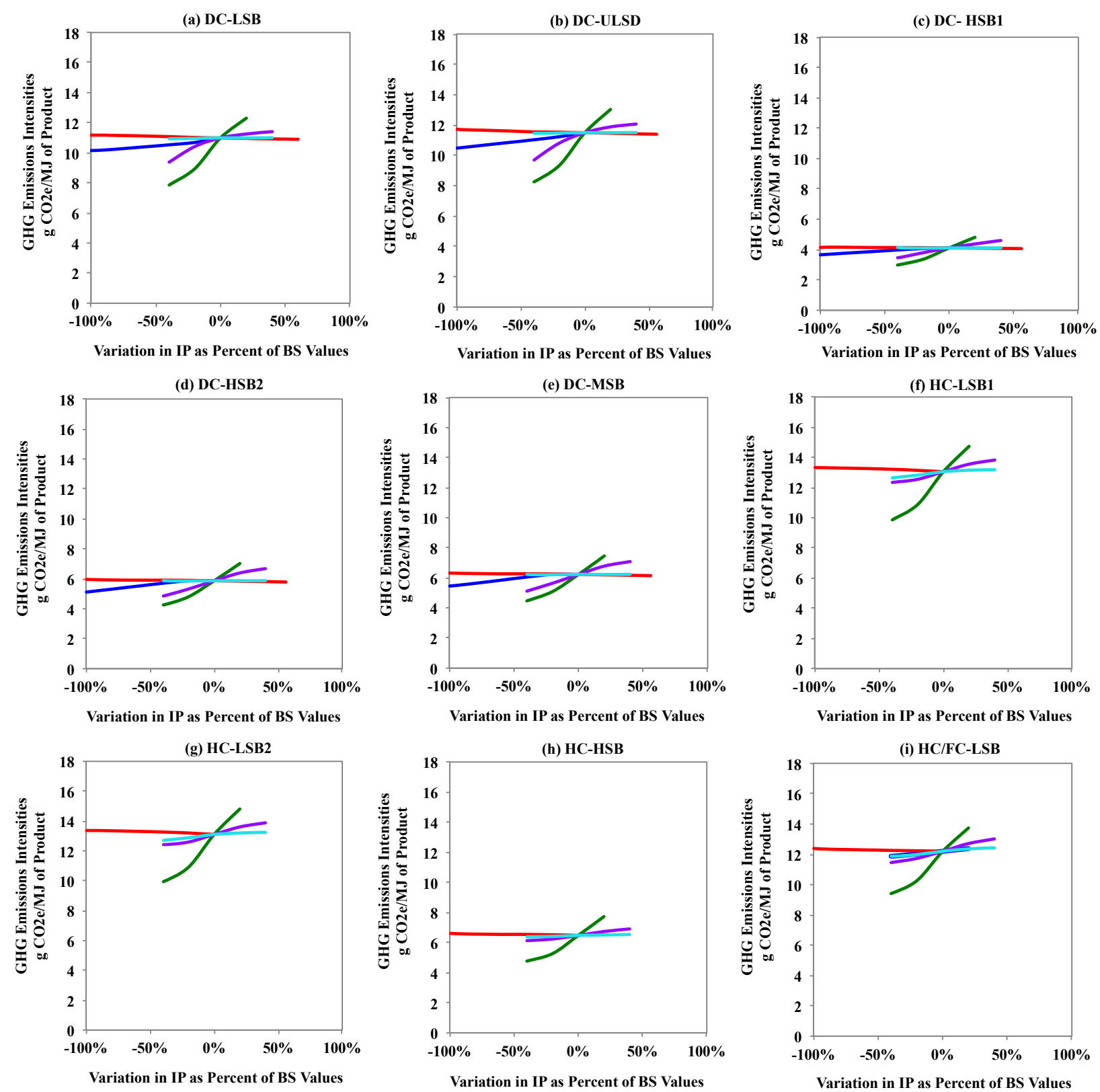

Coke Use —Fuel Gas Use —NG Requirements of PU

- Steam Requirements of PU

Electricity Requirements of PU

Figure S3. Impact on GHG intensities of upgrading products of variations in the use of upgrading by-products and variations in the energy inputs of the upgrader.

Notes: Spider graphs show the GHG intensities obtained by OSTUM 2.0's sensitivity analyses

run by varying the values of the energy inputs to the upgrader, one parameter at a time, in incremental steps of $\pm 20 \%$ of the base scenario values. For DC's SCO products (charts (a) to (e)), "Coke Use" sensitivity analysis varied the amount of coke used as fuel for boilers between $0 \%-15 \%$ of the coke production (all fuel needed for steam requirements is supplied by $15 \%$ of coke production), and more/less coke burned means less/more natural gas burned in boilers to 
meet constant steam requirements. For HC/FC's SCO product (chart (i)), the amount of coke burned as fuel of the fluid coker is varied between $13 \%-25 \%$ of the coke production (range suggested by the literature for the operation of a fluid coker), and more/less coke burned in the fluid coker means its efficiency decreases/increases (no other fuel is used as substitute). For all SCO products, the "Fuel Gas Use" analysis varied the amount of fuel gas used as natural gas substitute in heaters, boilers, and as steam methane reformer's feedstock between $0 \%-100 \%$ of the fuel gas production. More/less fuel gas us ed as fuel substitute means less/more natural gas used (constant energy requirements). For all SCO products, the "NG Requirements of PU" analysis varied the natural gas requirements of all the process units (both as fuel and as steam methane reformer's feedstock) at once and in $\pm 20 \%$ cumulative, incremental steps from the base scenario values until meeting the lowest/highest bound of natural gas requirements suggested by the literature. More/less natural gas requirements mean a less/more efficient upgrader. A similar methodology is followed in the "Steam Requirements of PU" and "Electricity Requirements of PU" analyses. Abbreviations: DC: delayed coking based upgrading; HC: hydroconversion based upgrading; HC/FC: combined hydroconversion and fluid coking based upgrading; LSB: light sweet SCO blend; ULSD: ultra-low sulfur diesel; HSB: heavy sour SCO blend; MSB: medium sour SCO blend; IP: input parameters; BS: base scenario; NG: natural gas; PU: process units. 


\section{Results: Correlation of SCO Blends' H/C Atomic Ratio with Upgrading GHG Intensities}

(a)

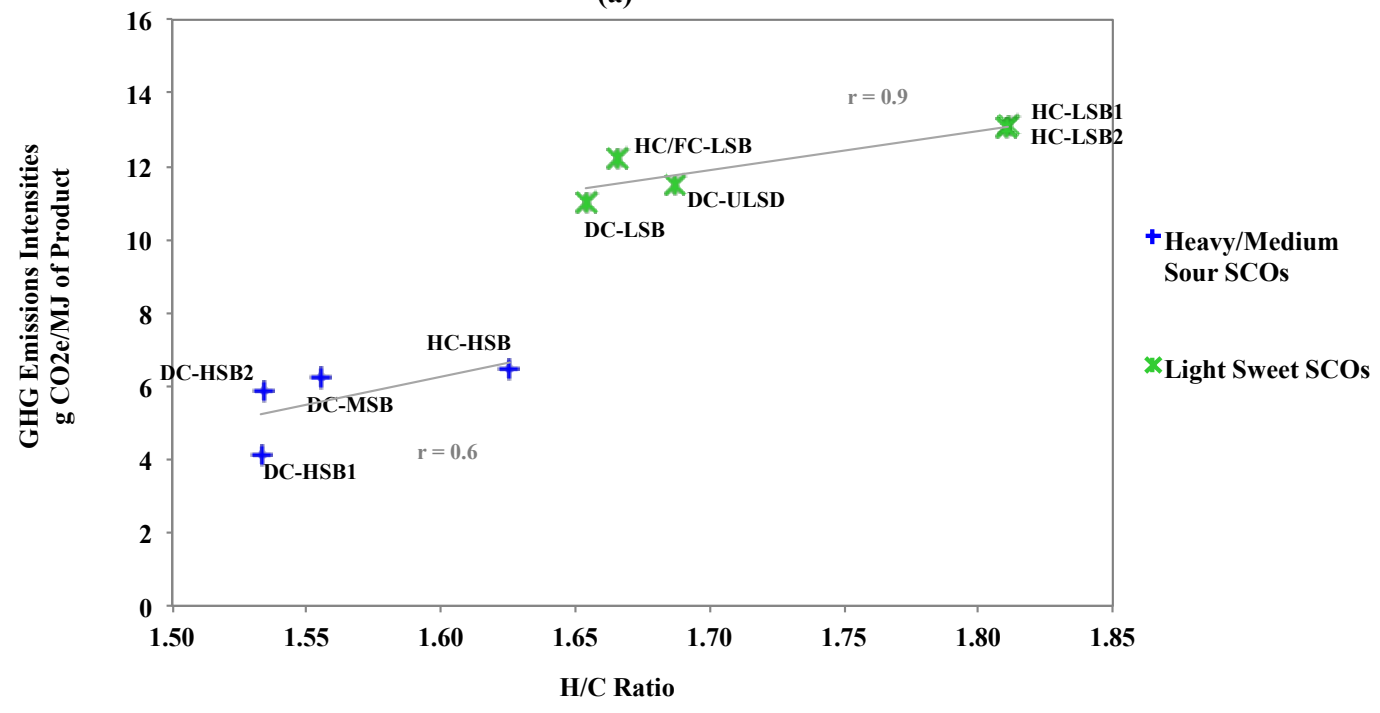

(b)

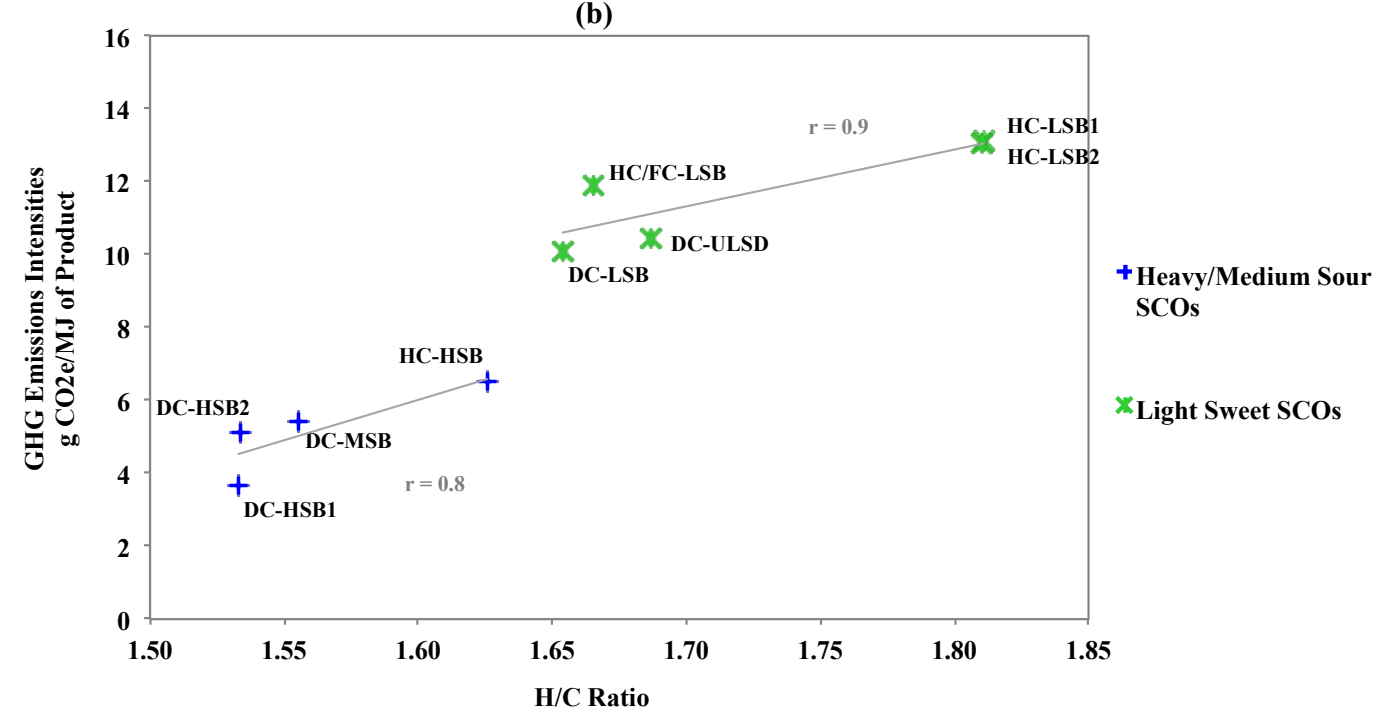

Figure S4. (a) Correlations between $\mathrm{H} / \mathrm{C}$ atomic ratio and $\mathrm{GHG}$ intensities of light sweet and medium/heavy sour SCO blends, obtained using base scenarios' input parameters, assumptions, and fuels. (b) Correlations between $\mathrm{H} / \mathrm{C}$ atomic ratio and $\mathrm{GHG}$ intensities of light sweet and medium/heavy sour SCO blends using same base scenarios' input parameters and assumptions as in (a), but replacing the use of coke in DC and HC/FC with natural gas.

Abbreviations: DC: delayed coking based upgrading; HC: hydroconversion based upgrading; HC/FC: combined hydroconversion and fluid coking based upgrading; LSB: light sweet SCO blend; HSB: heavy sour SCO blend; ULSD: ultra-low sulfur diesel. 
Figure S4 shows that, in general, there may be a strong positive correlation between OSTUM 2.0's estimated hydrogen to carbon $(\mathrm{H} / \mathrm{C})$ atomic ratios of light sweet SCO blends and their associated GHG intensities. Light sweet SCOs are blends of fully upgraded products that receive different levels of hydroprocessing, either only in the hydrotreating stage (e.g., DC's light sweet SCO products) or both in the conversion and hydrotreating stages (e.g., HC, HC/FC's light sweet SCO products). The addition of hydrogen to these products to improve their quality properties is a significant driver of its GHG emissions (hydrogen is an energy-intensive energy input to the upgrading process). This is the main reason of the potential good correlation observed between $\mathrm{H} / \mathrm{C}$ atomic ratio and GHG intensities of light sweet SCO products. Since the GHG intensities of these products are mainly impacted by the energy used to produce the hydrogen they consumed, the use of less carbon-intensive fuels than coke for heat/steam production does not impact their GHG intensities significantly (see Figure S4 (b)). It is important to acknowledge that the number of GHG intensities estimations included in this analysis is limited by the scope of this paper, and a more comprehensive analysis of the relationship between $\mathrm{H} / \mathrm{C}$ atomic ratio and $\mathrm{GHG}$ intensities is needed to confirm this preliminary insights.

The correlation between the $\mathrm{H} / \mathrm{C}$ atomic ratio and the $\mathrm{GHG}$ intensities of medium/heavy sour SCO blends may be less strong than that of the light sweet SCOs. The medium/heavy sour SCO blends from DC are mainly composed of product streams (e.g., virgin middle distillate fractions, heavy vacuum gas oils, and coking products) from processes that don't add hydrogen to the bitumen. Their processing consists of fractionation and thermal cracking steps, and their associated GHG intensities are therefore mostly impacted by the carbon intensity and flow rates of the fuels burned to 
meet the heat and steam demand of these processes. For example, DC-HSB1 has the lowest base scenario emission intensity $\left(4.1 \mathrm{~g} \mathrm{CO}_{2} \mathrm{e} / \mathrm{MJ}\right.$ of HSB1) of DC's medium/heavy sour SCOs because it is composed mostly of virgin vacuum gas oils, and therefore the energy and GHG emissions allocated to it come mainly from the fractionation stage. DCMSB has the highest GHG intensity of DC-derived medium/heavy sour blends $(6.2 \mathrm{~g}$ $\mathrm{CO}_{2} \mathrm{e} / \mathrm{MJ}$ of $\mathrm{MSB}$ ) because it blends more product streams than the other heavy sour SCO products (a mix of vacuum gas oils and all cracked products consuming significant amounts of steam in stripping). In contrast, HC's HSB receives some degree of hydroprocessing (it is composed of some hydrocracked and hydrotreated product streams) and therefore its GHG intensity follows a more linear trend with respect to other co-products from $\mathrm{HC}$.

When the use of carbon-intensive coke (as fuel for steam production) in DC was substituted with natural gas (see Figure S4 (b)), a stronger correlation between H/C atomic ratio and GHG intensities of medium/heavy sour SCOs was obtained. However, a more comprehensive analysis is needed to determine if $\mathrm{H} / \mathrm{C}$ atomic ratio is an appropriate GHG intensity indicator for medium/heavy sour SCO products. 


\section{Results: Preliminary Well-to-Wheel GHG Intensities of Oil Sands-Derived Fuel Production Pathways Involving Evaluated Upgrading Technologies}

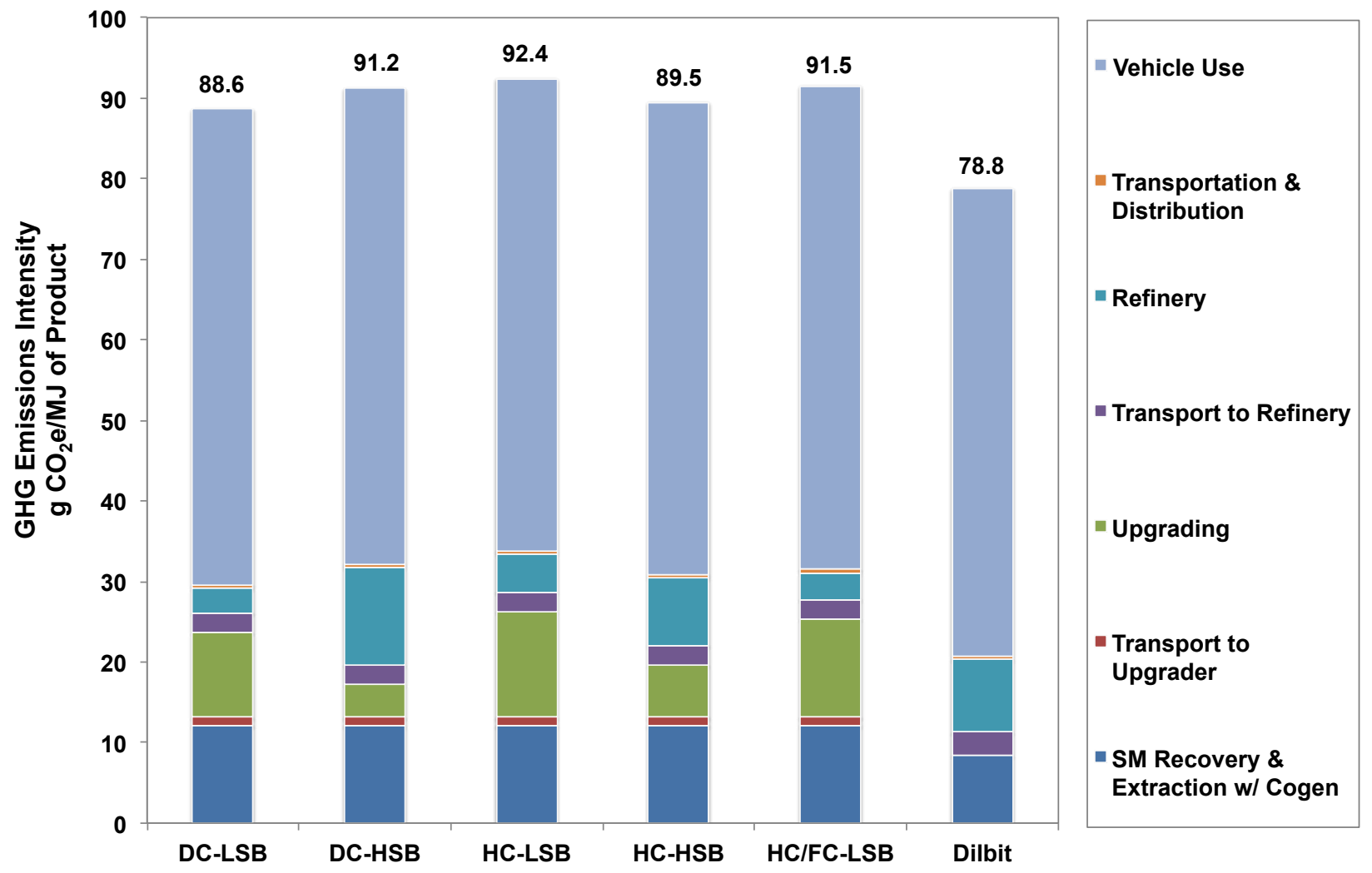

Figure S5. Preliminary well-to-wheel (WTW) GHG intensities of oil sands-derived fuel production pathways involving the evaluated upgrading technologies (producing SCO blends of different properties) and bitumen dilution.

Abbreviations: GHG: greenhouse gas; DC: delayed coking based upgrading; HC: hydroconversion based upgrading; HC/FC: combined hydroconversion and fluid coking based upgrading; LSB: light sweet SCO blend; HSB: heavy sour SCO blend; dilbit: diluted bitumen; SM Recovery \& Extraction w/ Cogen: surface mining recovery and extraction with cogeneration.

Notes: the preliminary WTW GHG intensities use the following sources to estimate emissions for each life cycle stage: surface mining recovery and extraction with cogeneration stage: all production pathways use the median value of the GHG intensity distribution $(51 \mathrm{~kg} \mathrm{CO} 2 \mathrm{e} / \mathrm{bbl}$ dilbit, converted to appropriate units in each production pathway) generated by GHOST-SE

(statistically enhanced version of the GreenHouse gas emissions of current Oil Sands Technologies model) for a surface mining and dilution project producing diluted bitumen (dilbit; emissions from diluent production are included in this stage), as reported by Sleep et al. ${ }^{51}$ Transport to upgrader stage: all production pathways involving upgrading use the arithmetic average of the range of low/high GHG intensities reported by Bergerson et al. ${ }^{52}$ for transporting dilbit to an upgrader ( $\left.1 \mathrm{~g} \mathrm{CO}_{2} \mathrm{e} / \mathrm{MJ} \mathrm{SCO}\right)$. Upgrading stage: DC-LSB production pathway uses OSTUM 2.0's baseline results when producing a light sweet SCO blend through DC with quality properties similar to OSA blend. DC-HSB's production pathway uses OSTUM 2.0's baseline results when producing a heavy sour SCO blend through DC with quality properties similar to 
OSH blend. HC-LSB uses OSTUM 2.0's baseline results when producing a light sweet SCO blend through HC with quality properties similar to the PAS blend. HC-HSB uses OSTUM 2.0's baseline results when producing a heavy sour $\mathrm{SCO}$ blend through $\mathrm{HC}$ with quality properties similar to the AHS blend. HC/FC-LSB uses OSTUM 2.0's baseline results when producing a light sweet SCO blend through HC/FC with quality properties similar to the SSP blend. Transport to refinery stage: in all production pathways involving upgrading, the arithmetic average of the range of low/high GHG intensities reported by Bergerson et al. ${ }^{52}$ for transporting SCO to a refinery is used (2.5 $\left.\mathrm{g} \mathrm{CO}_{2} \mathrm{e} / \mathrm{MJ} \mathrm{SCO}\right)$; in the dilbit production pathway, the arithmetic average of the range of low/high GHG intensities reported by Bergerson et al. ${ }^{52}$ for transporting dilbit to a refinery (2.9 $\mathrm{g} \mathrm{CO}_{2} \mathrm{e} / \mathrm{MJ}$ dilbit) is used. Refinery stage: in the DC-LSB production pathway, the refinery GHG intensity is obtained running the open-source version of PRELIM v1.3 $3^{53}$ when simulating the refining of OSA crude oil blend in a coking refinery scheme with default values for all the model's input parameters (applied in all production pathways); in the DC-HSB production pathway, PRELIM $v 1.3^{53}$ is run using the OSH crude oil blend's assay; in the HC-LSB's production pathway, PRELIM v1.3 $3^{53}$ uses the PAS crude oil blend as feedstock; in the HC-HSB's production pathway, PRELIM v1.3 $3^{53}$ uses the AHS assay as crude oil feedstock; in the HC/FC-LSB's production pathway, PRELIM $v 1.3^{53}$ uses the SSP assay as feedstock to the coking refinery; finally, in the Dilbit production pathway, PRELIM v1.353 uses the Borealis Heavy Blend dilbit assay as the feedstock to the coking-based refinery. Fuel transportation and distribution stage: all production pathways use a constant GHG intensity value reported by TIAX LLC ${ }^{54}$ of $0.5 \mathrm{~kg}$ $\mathrm{CO}_{2} \mathrm{e} / \mathrm{GJ}$ RFG, converted to appropriate units. Vehicle use stage: all production pathways use a constant GHG intensity of $68.1 \mathrm{~g} \mathrm{CO}_{2} \mathrm{e} / \mathrm{MJ}$ RFG obtained from the open-source GHGenius model ${ }^{55}$ and converted to appropriate units. The following relevant conversion factors were used to obtain the GHG intensity of each life cycle stage in units of $\mathrm{g} \mathrm{CO}_{2} \mathrm{e} / \mathrm{MJ}$ of SCO or dilbit: dilbit $\mathrm{LHV}$ of $38 \mathrm{GJ} / \mathrm{m}^{3}, 0.80$ (g CO $2 \mathrm{e} / \mathrm{MJ}$ dilbit)/(g CO $2 \mathrm{e} / \mathrm{MJ}$ bitumen), 1.15 ( $\left.\mathrm{g} \mathrm{CO}_{2} \mathrm{e} / \mathrm{MJ} \mathrm{SCO}\right) /(\mathrm{g}$ $\mathrm{CO}_{2} \mathrm{e} / \mathrm{MJ}$ bitumen), conventional gasoline LHV of $32.4 \mathrm{GJ} / \mathrm{m}^{3}$, SCO LHV of $37.3 \mathrm{GJ} / \mathrm{m}^{3}$. 
Results: Comparison of GHG Intensities of Producing ULSD from Diluted Bitumen Feedstocks: Upgrader (OSTUM 2.0) and Refinery (PRELIM v1.2.1) Models

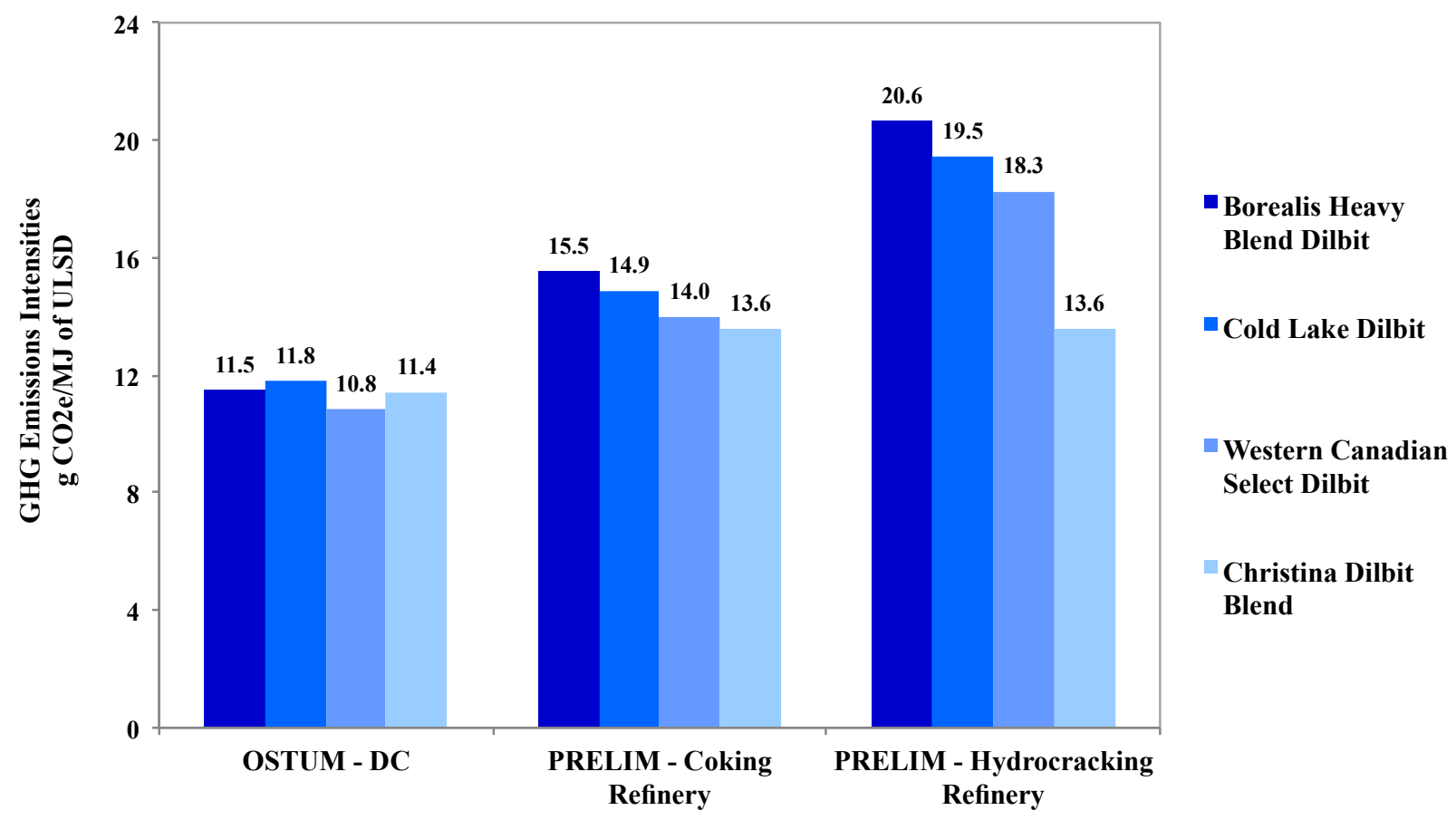

Figure S6. Comparison of GHG intensities of different ULSD production pathways.

Notes: bars represent the GHG intensities of ULSD obtained with OSTUM 2.0's DC base scenario and with PRELIM v1.2.1's ${ }^{56}$ default values of input parameters using different diluted bitumen (dilbit) feedstocks. The dilbit feedstocks used in both OSTUM 2.0 and PRELIM v1.2.1 $1^{56}$ are listed in the legend. 


\section{Results: Comparison of OSTUM 2.0's HC Results with Shell's Scotford Energy Use Data}

(a)
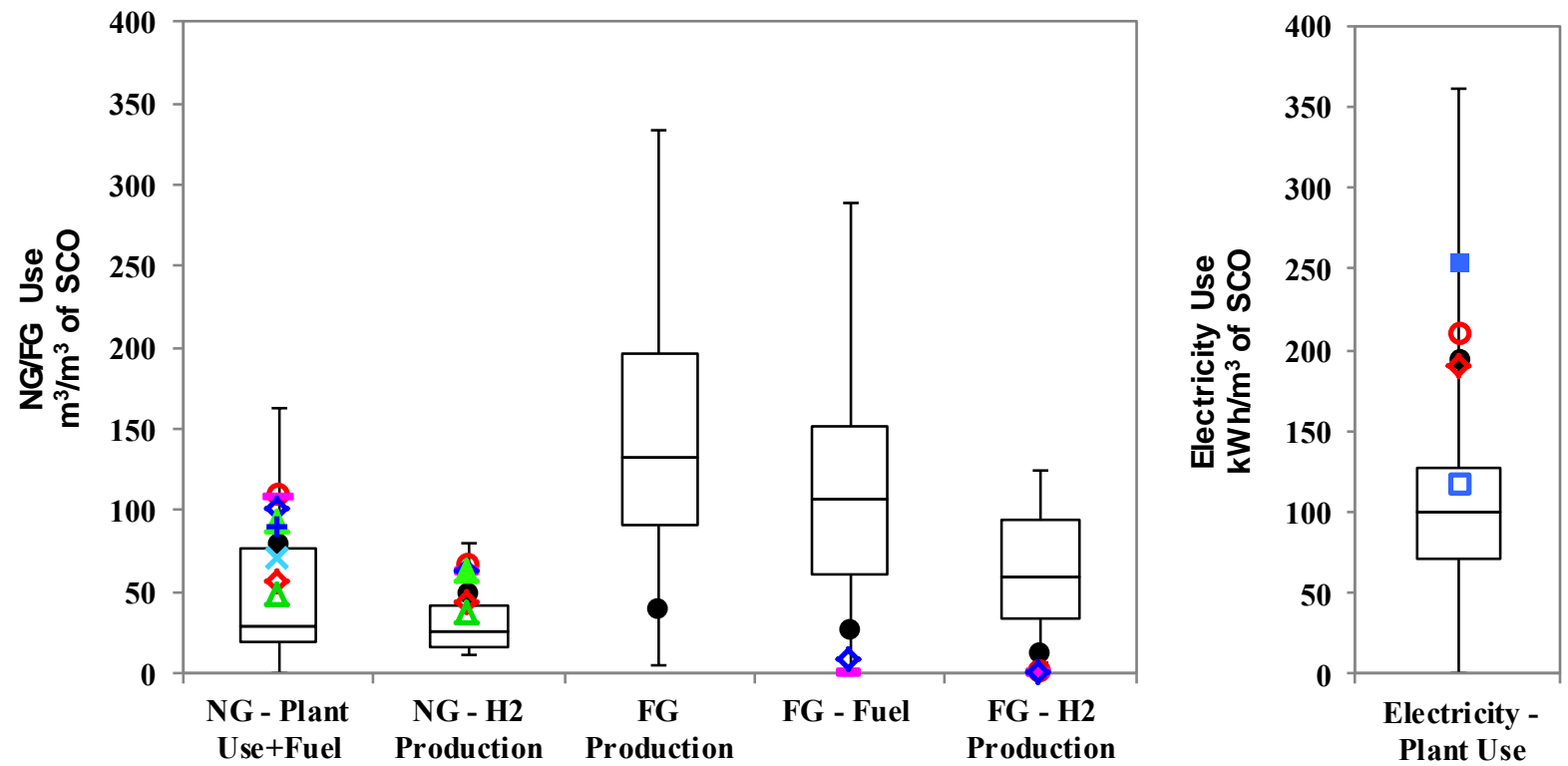

(b)
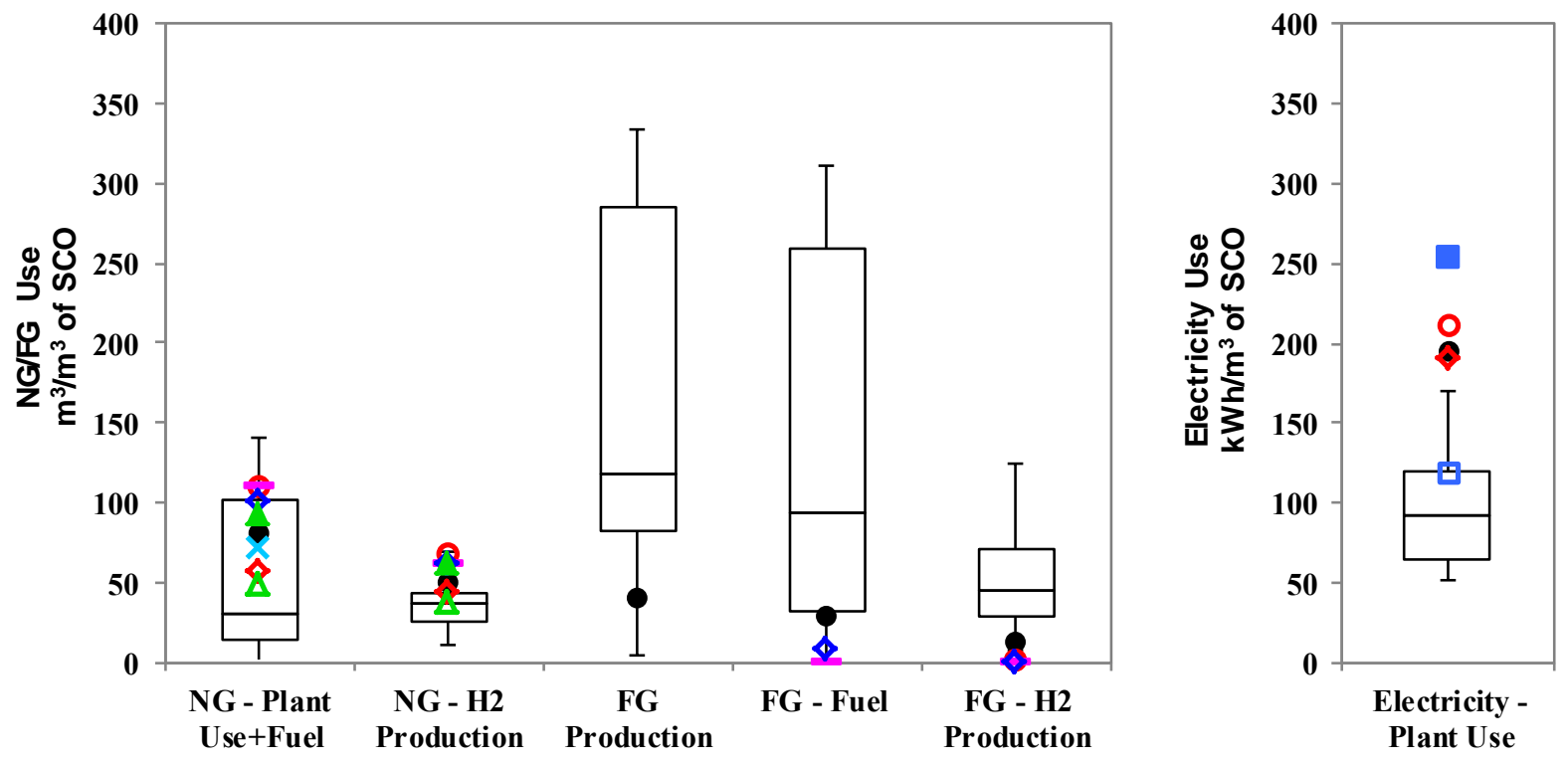

W N Req.

$\bigcirc$ High Case Scenario

$\diamond$ Low Case Scenario

- No FG Use

$\diamond$ Low FG Use 
Figure S7. Comparison of OSTUM 2.0's energy use results for different scenarios with energy use statistics for Shell's HC upgrading operations calculated based on data reported by $A E R^{45}$ for the period (a) 2003-2016, (b) 2011-2016.

Notes: Only OSTUM 2.0's energy use results that vary significantly from the base scenario results are shown. Lower edge of boxes in boxplots is $10^{\text {th }}$ percentile, upper edge is $90^{\text {th }}$ percentile, line inside boxes is the median. Whiskers extend to the smallest and largest observations that are not outliers. Outliers (values lying more than one and a half times the length of the boxes from either end of the box) are not shown to improve readability. "Low FG Use" scenario assumes that $20 \%$ of fuel gas generation is used as fuel. Low NG, steam, or electricity requirements scenarios use the lower bound of literature values as the natural gas, steam or electricity requirements of process units. High NG, steam, or electricity requirements scenarios use the upper bound of literature values as the natural gas, steam or electricity requirements of process units. Abbreviations: NG: natural gas; FG: fuel gas; SCO: synthetic crude oil; H2: hydrogen; Req.: requirements; Elect.: electricity. 


\section{Results: Comparison of OSTUM 2.0's DC Results with Suncor's Energy Use Data}

Figure S8 presents a comparison of OSTUM 2.0's DC energy use results from the scenario/sensitivity analyses with the energy use data for Suncor's mining and DC upgrading operations reported by AER for the period (a) 1983-2016, (b) 2008-2016. Data reported by Suncor to AER is aggregated from its upgrading and mining operations. Upgrading by-products fuel gas and coke are known to be consumed within the upgrading plant only, and therefore comparison with OSTUM 2.0's results is straightforward. However, natural gas and electricity are also used in bitumen recovery and extraction operations. The comparison of these data with OSTUM 2.0's results is informative as it can provide insight on the approximate fractions of energy use that can be attributed to upgrading operations. This is of interest for the industry and researchers estimating GHG emissions from aggregated oil sands plants data.

There is considerable variation in the energy use data reported by Suncor between 1983 and 2016. Data on the amount of coke used as fuel are among the indicators showing larger historical variability. In recent years (2008-2016) this variation has generally been reduced, as expected due to the shorter timeframe, and the amounts of coke used have decreased (data are closer together in the lower end of the scale) due to increasingly stringent regulations in air quality/GHG emissions. OSTUM 2.0 can reproduce the industry's variability in coke use during recent years by running scenarios representing more/less efficient operations (low/high GHG cases), and scenarios where more/less alternative fuels (e.g., fuel gas, natural gas) are used 
instead of coke (market factors and emissions allowances play a role in determining how much of each fuel is burned).

The variability in fuel gas use has also decreased over time. Recent years' variability may be associated with changes in the energy efficiency (fuel requirements) of the operations, the availability of fuel gas (it is known that Suncor sells a fraction of its fuel gas to the petrochemical industry), of other by-products (e.g., coke), and of natural gas. Suncor uses almost no fuel gas as feedstock for hydrogen production.

OSTUM 2.0 is able to reproduce some of the variability observed in recent years in the use of natural gas. OSTUM 2.0's natural gas use estimates are at the low end of the scale since the data reported by Suncor also includes the use of natural gas in bitumen production. OSTUM 2.0's causes of variations in natural gas use are mainly due to different assumptions in the amount of fuel substitutes (fuel gas/coke) used, and the efficiency of the operations. Similarly, the use of electricity reported by Suncor includes the recovery/extraction stages, and therefore OSTUM 2.0's results are expected to be smaller than the range reported by the industry. 
(a)
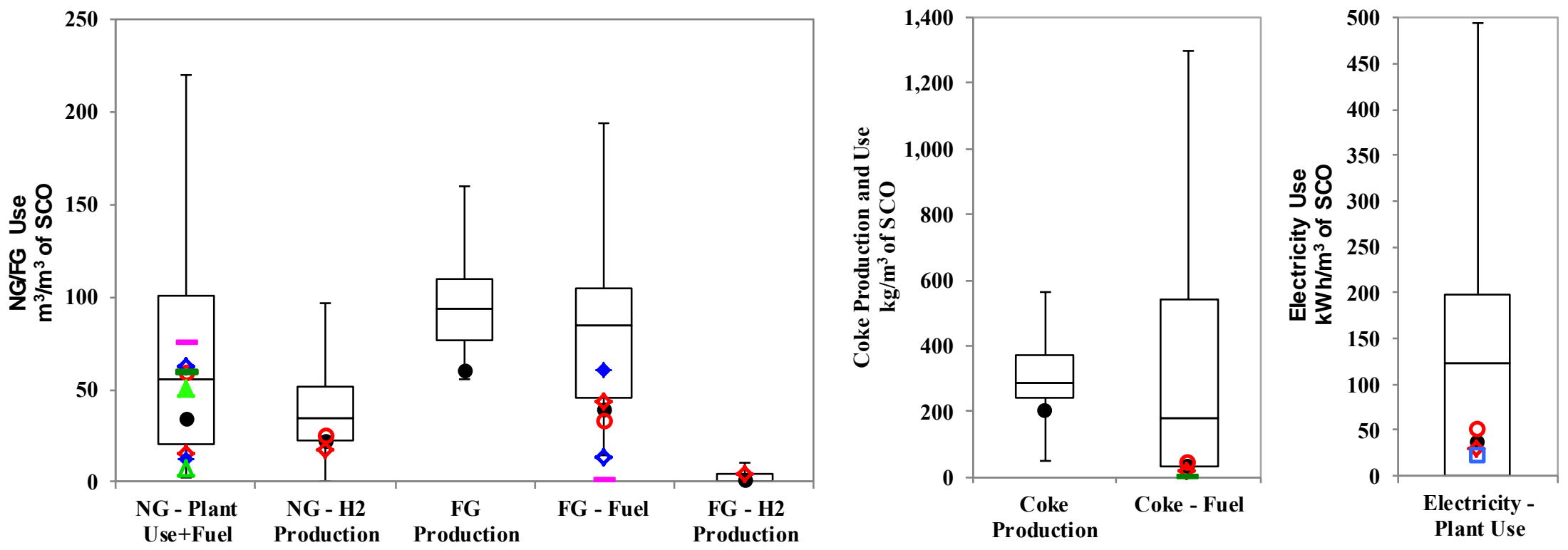

(b)
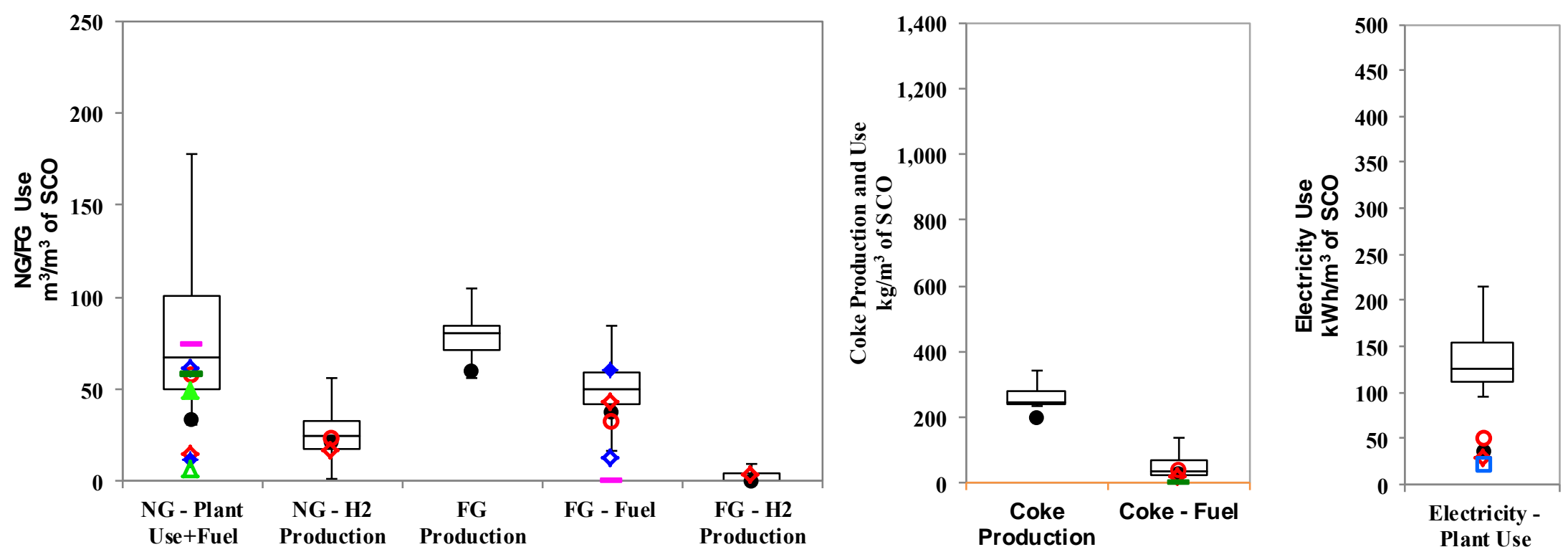

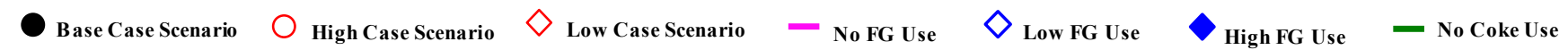

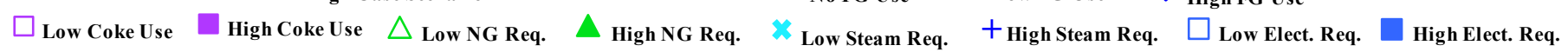


Figure S8. Comparison of OSTUM 2.0's energy use results for different scenarios with energy use statistics for Suncor's mining and DC upgrading operations calculated based on data reported by $A E R^{45}$ for the period (a) 1983-2016, (b) 2008-2016.

Notes: Only OSTUM 2.0's energy use results that significantly vary from the base scenario results are shown. Lower edge of boxes in boxplots is $10^{\text {th }}$ percentile, upper edge is $90^{\text {th }}$ percentile, line inside boxes is the median. Whiskers extend to the smallest and largest observations that are not outliers. Outliers (values lying more than one and a half times the length of the boxes from either end of the box) are not shown to improve readability. "Low FG Use" scenario assumes that $20 \%$ of fuel gas generation is used as fuel. "High FG Use" assumes that $100 \%$ of the fuel gas generation is used as fuel. Low NG, steam, or electricity requirements scenarios use the lower bound of literature values as the natural gas, steam or electricity requirements of process units. High NG, steam, or electricity requirements scenarios use the upper bound of literature values as the natural gas, steam or electricity requirements of process units. Abbreviations: NG: natural gas; FG: fuel gas; SCO: synthetic crude oil; H2: hydrogen; Req.: requirements; Elect: electricity. 


\section{Results: Comparison of OSTUM 2.0 Results with Syncrude's Energy Use Data}

Figure S9 presents a comparison of OSTUM 2.0's energy use results for different scenarios with energy use data for Syncrude's mining and HC/FC upgrading operations reported by AER for the period (a) 1983-2016, (b) 2007-2016. Similar to Suncor's data, Syncrude's energy use data from the recovery, extraction, and upgrading stages are aggregated. However, it is not known if this operator uses its byproducts fuel gas and coke exclusively in its upgrading operations.

In contrast with Suncor's data, Syncrude's historical coke use data present little variability. The fraction of coke production used as fuel has consistently decreased through the years, stabilizing at $21 \%$ during $2007-2016$. This consistency in fuel usage may be related to the design operation of the fluid coker, which recovers heat from coke. OSTUM 2.0's coke production estimates are informed by typical fluid coking operations reported in the refining literature and are lower than Syncrude's reported coke production. Public information about Syncrude's fluid coking operations that would allow an investigation of this discrepancy is not available.

Syncrude's fuel gas production data is also higher than OSTUM 2.0's estimates, which are guided by literature values of typical sour gas yield in the hydroconverter and fluid coker. However, if HC/FC's kinetic models were adjusted to increase fuel gas production to Syncrude's levels, OSTUM 2.0's natural gas consumption would decrease to approximate Syncrude's median or a lower amount.

The data showing the largest variability are the use of fuel gas and natural gas as fuel, as well as the use of electricity. The variability in these data has decreased in recent years, and OSTUM 2.0's results from changes in efficiency and availability of fuel gas 
are able to reproduce some of this variability. Syncrude does not report any fuel gas used as feedstock for hydrogen production. 
(a)
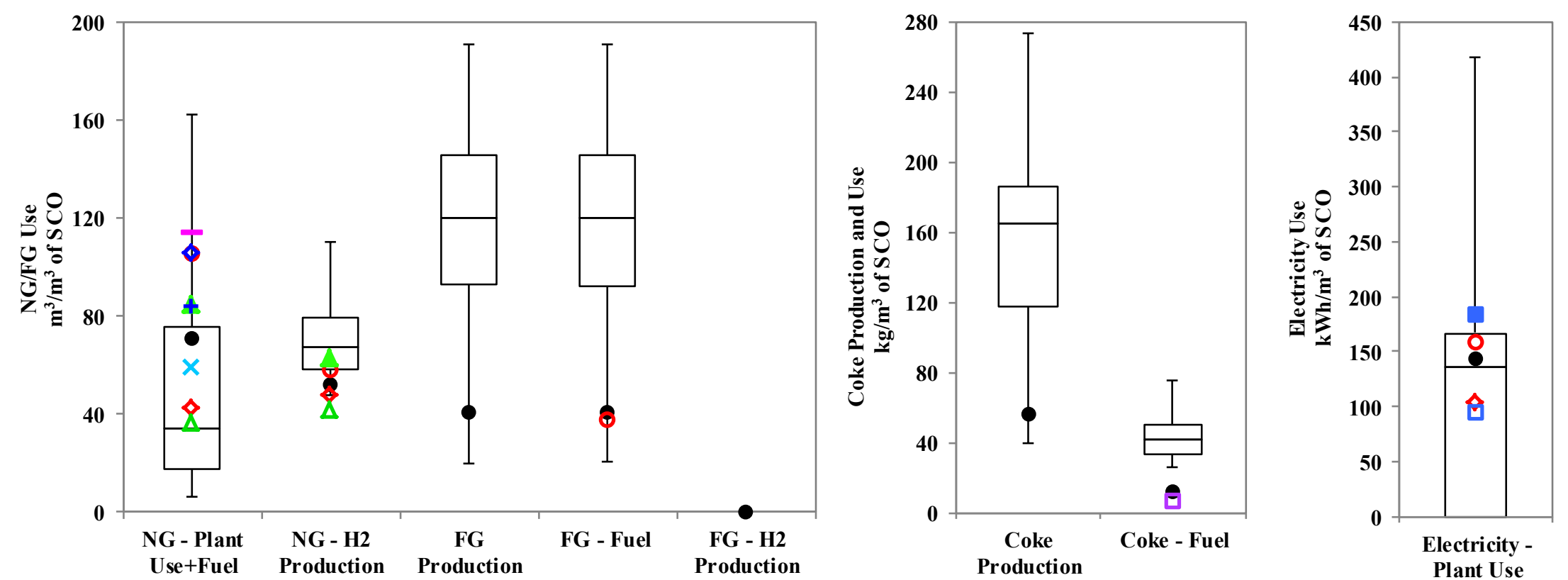

(b)
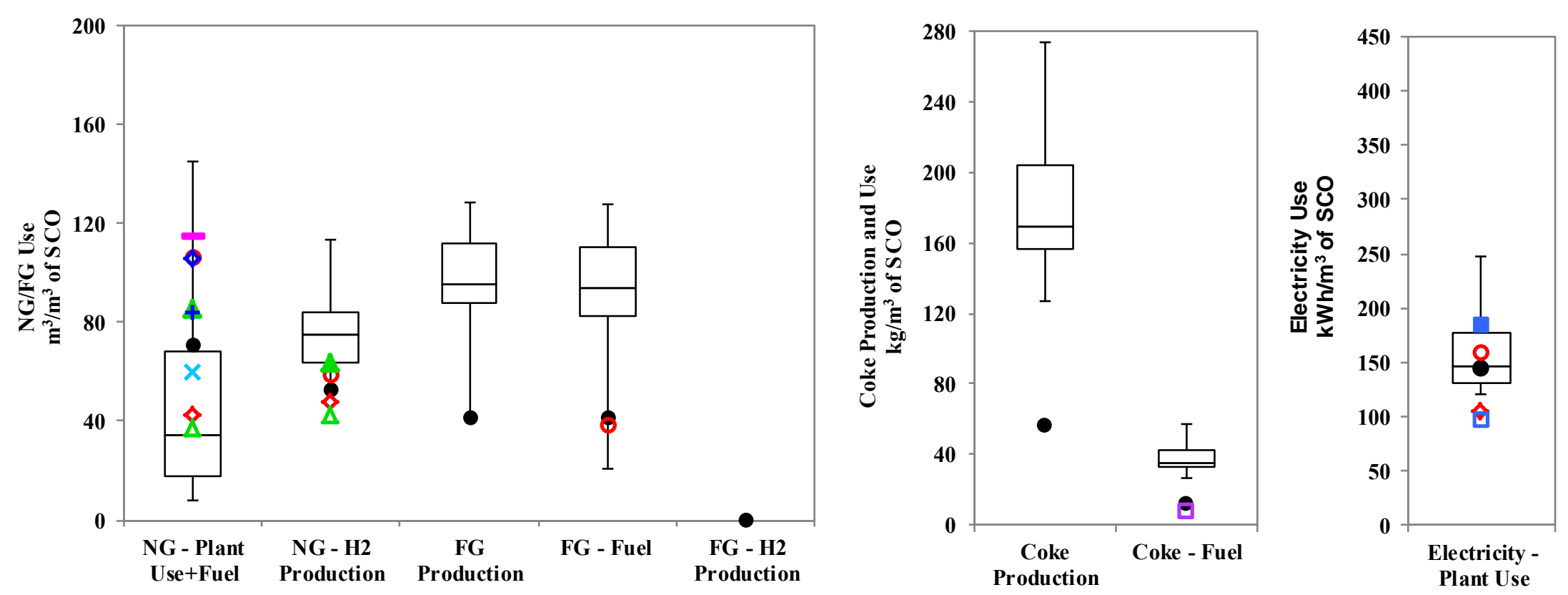

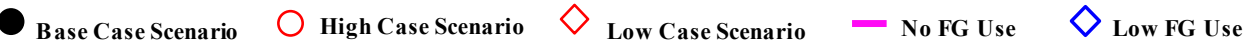


Figure S9. Comparison of OSTUM 2.0's energy use results for different scenarios with energy use data for Syncrude's mining and HC/FC upgrading operations based on data reported by $A E R^{45}$ for the period (a) 1983-2016, (b) 2007-2016.

Notes: Only OSTUM 2.0's energy use results that significantly vary from the base scenario results are shown. Lower edge of boxes in boxplots is $10^{\text {th }}$ percentile, upper edge is $90^{\text {th }}$ percentile, line inside boxes is the median. Whiskers extend to the smallest and largest observations that are not outliers. Outliers (values lying more than one and a half times the length of the boxes from either end of the box) are not shown to improve readability. "Low FG Use" scenario assumes that $20 \%$ of fuel gas generation is used as fuel. "Low Coke Use" scenario assumes that $15 \%$ of the plant's coke generation is used as the fluid coker's fuel. "High Coke Use" scenario assumes that $25 \%$ of the plant's coke generation is used as the fluid coker's fuel. Low NG, steam, or electricity requirements scenarios use the lower bound of literature values as the natural gas, steam or electricity requirements of process units. High NG, steam, or electricity requirements scenarios use the upper bound of literature values as the natural gas, steam or electricity requirements of process units. Abbreviations: NG: natural gas; FG: fuel gas; SCO: synthetic crude oil; H2: hydrogen; Req.: requirements; Elect: electricity 


\section{References}

1. Bitumen \& Heavy Oil Upgraders. http://www.oilsandsmagazine.com/projects/bitumen-upgraders (accessed Oct 9, 2018).

2. Facts About Alberta's Oil Sands and Its Industry. Oil Sands Discovery Centre, Alberta Culture and Tourism, Historic Sites and Museums Branch. Fort McMurray, Alberta. 2015.

3. Gray, M. R. Upgrading Oilsands Bitumen and Heavy Oil. Pica Pica Press. The University of Alberta Press. Edmonton, Alberta. 2015.

4. Sawarkar, A. N., Pandit, A. B., Samant, S. D., Joshi, J. B. Petroleum Residue Upgrading Via Delayed Coking: A Review. The Canadian Journal of Chemical Engineering. 2007. 85 (1), 1-24.

5. Adams, J. Coking 101: An Introduction to Delayed Coking. Adams Project Managers Inc. Process Engineering Associates, LLC.

6. Ellis, P. J., Paul, C. A. Tutorial: Delayed Coking Fundamentals. In AIChE 1998 Spring National Meeting: Topical Conference on Refinery Processing. Delayed Coking Tutorial Session. Vol. Paper 29a. Great Lakes Carbon Corporation. New Orleans, LA, 1998.

7. Martinez, J., Sanchez, J. L., Ancheyta, J., Ruiz, R. S. A Review of Process Aspects and Modeling of Ebullated Bed Reactors for Hydrocracking of Heavy Oils. Catalysis Reviews. 2010. 52, 60-105.

8. Syncrude Upgrading. http://www.syncrude.ca/our-process/understandingour-process/upgrading/ (accessed January 26, 2018).

9. Yui, S., Chung, K. H. Processing Oil Sands Bitumen is Syncrude's R\&D Focus. Oil \& Gas Journal. 2001.

10. https://www.crudemonitor.ca Crude Quality Inc. Edmonton, Alberta. 2019.

11. Goossens, A. G. Prediction of the Hydrogen Content of Petroleum Fractions. Industrial \& Engineering Chemistry Research. 1997. 36 (6), 2500-2504.

12. Choudhary, T. V., Meier, P. F. Characterization of Heavy Petroleum Feedstocks. Fuel Processing Technology. 2008. 89, 697-703.

13. Goossens, A. G. Prediction of Molecular Weight of Petroleum Fractions. Industrial \& Engineering Chemistry Research. 1996. 35, 985-988.

14. Volk, M., Wisecarver, K.D., Sheppard, C.M. Fundamentals of Delayed Coking. University of Tulsa. Tulsa, OK. 2002.

15. Gary, J. H., Handwerk, G. E. Petroleum Refining, Technology and Economics. Fourth Edition. Marcel Dekker. New York, NY. 2001.

16. Ancheyta, J. J. Modeling of Processes and Reactors for Upgrading of Heavy Petroleum. CRC Press, Taylor \& Francis Group. Boca Raton, FL. 2013.

17. Sánchez, S., Rodríguez, M. A., Ancheyta, J. Kinetic Model for Moderate Hydrocracking of Heavy Oils. Industrial \& Engineering Chemistry Research. 2005. 44, 9409-9413. 
18. Danial-Fortain, P., Gauthier, T., Merdrignac, I., Budzinski, H. Reactivity Study of Athabasca Vacuum Residue in Hydroconversion Conditions. Catalysis Today. 2010. 150, 255-263.

19. Yui, S., Sanford, E. C. Mild Hydrocracking of Bitumen-Derived Coker and Hydrocracker Heavy Gas Oils: Kinetics, Product Yields, and Product Properties. Industrial \& Engineering Chemistry Research. 1989. 28 (9), 1278-1284.

20. Alvarez-Majmutov, A., Chen, J., Munteanu, M. Simulation of Bitumen Upgrading Processes. Petroleum Technology Quarterly. 2013. Q2, 31-35.

21. Fahim, M. A., Al-Sahhaf, T. A., Elkilani, A. S. Chapter 6: Thermal Cracking and Coking. In Fundamentals of Petroleum Refining. Elsevier. Great Britain, 2010.

22. Maples, R. E. Petroleum Refinery Process Economics. PennWell Books. Tulsa, Oklahoma, 1993.

23. Yui, S. Removing Diolefins from Coker Naphtha Necessary Before Hydrotreating. Oil \& Gas Journal. 1999. 97 (36), 64-67.

24. Edgar, M. D. Hydrotreating Q\&A. In 1993 NPRA Annual Meeting. San Antonio, Texas. 1993.

25. Yui, S., Sanford, E. C. Kinetics of Aromatics Hydrogenation of BitumenDerived Gas Oils. The Canadian Journal of Chemical Engineering. 1991. 69, 1087-1095.

26. Yui, S. Hydrotreating of Bitumen-Derived Coker Gas Oil: Kinetics of Hydrodesulfurization, Hydrodenitrogenation, and Mild Hydrocracking, and Correlations to Predict Product Yields and Properties. AOSTRA Journal of Research. 1989. 5, 211-224.

27. Parkash, S. Refining Processes Handbook. Elsevier. Burlington, MA. 2003.

28. Charpentier, A. D., Kofoworola, O., Bergerson, J. A., MacLean, H. L. Life Cycle Greenhouse Gas Emissions of Current Oil Sands Technologies: GHOST Model Development and Illustrative Application. Environmental Science \& Technology. 2011. 45, 9393-9404.

29. Blackmore, T. E. Synthetic Crudes: A Gro wing Opportunity. Crude Oil Quality Association Meeting, New Orleans, LA. Omnicon Consultants Inc. January 29, 2004.

30. Material Safety Data Sheet for Albian Heavy Synthetic Crude. Shell Canada Limited. December 4, 2008.

31. Palmer, R. E., Torrisi, S. Hydrotreater Revamps for ULSD Fuel. PTQ Revamps and Operations. Revamps Issue. PTQ Magazine. 2003. 15 - 18.

32. Ultra Low-Sulfur Diesel Fuel Product Specifications. Suncor Energy. Calgary, Alberta. 2006.

33. James, H. Shrinkage Loses Resulting from Liquid Hydrocarbon Blending. MEC Corporation. 2009.

34. Tunnah, B. G., Appelbaum, B. Power Systems: Use of Fuel Cells in Refining. In Energy Management Handbook. Gulf Publishing Company. Houston, Texas. 1979.

35. Leprince, P. Petroleum Refining: Conversion Processes. Editions Technip. Paris, 2001. 
36. Meyers, R. A. Handbook of Petroleum Refining Processes. 3rd Edition. McGraw-Hill. 2004.

37. Antos, G. J., Aitani, A. M. Catalytic Naphtha Reforming. 2nd Edition. Marcel Dekker Inc. USA. 2004.

38. Moshfeghian, M. Gas Sweetening-Part 1: Comparison of Amines. http://www.jmcampbell.com/tip-of-the-month/2014/07/gas-sweetening-part1-comparison-of-amines/.

39. Satyadileep, D., Berrouk, A. S., Peters, C. J., Aziz, A. A. Improve Amine Unit Efficiency by Optimizing Operating Conditions. Gas Processing News. 2015.

40. Spath, P. L., Mann, M. K. Life Cycle Assessment of Hydrogen Production via Natural Gas Steam Reforming. US Department of Energy, National Renewable Energy Laboratory. Golden, Colorado. February 2001.

41. Orlando, J. A. Chapter 3: Heat Recovery and Usage. In Cogeneration Design Guide. American Society of Heating, Refrigerating and AirConditioning Engineers. 1996.

42. Flin, D. Cogeneration: A User's Guide. The Institution of Engineering and Technology. UK. 2010.

43. Raseev, S. Thermal and Catalytic Processes in Petroleum Refining. Taylor \& Francis Group, Marcel Dekker, Inc. New York, NY. 2003.

44. Safety Data Sheet Diesel Fuel. Petro-Canada. Calgary, Alberta, Canada, 2018.

45. ST39: Alberta Mineable Oil Sands Plant Statistics Monthly Supplement. Alberta Energy Regulator. February 2018.

46. Rajyalakshmi, S., Patwardhan, K., Balaramakrishna, P. V. Optimised Hydrogen Production by Steam Reforming: Part I. Digital Refining. 2012. PTQ Q1 2012.

47. Khojasteh Salkuyeh, Y., Saville, B. A., MacLean, H. L. Techno-economic Analysis and Life Cycle Assessment of Hydrogen Production Technologies from Natural Gas. International Journal of Hydrogen Energy. 2017. 42 (30), 18894- 18909.

48. Molburg, J. C., Doctor, R. D. Hydrogen from Steam-Methane Reforming with CO2 Capture. 20th Annual International Pittsburgh Coal Conference. Pittsburgh, Pensylvannia. June 30, 2003.

49. Jechura, J. Hydrogen from Natural Gas Via Steam Methane Reforming. Colorado School of Mines. 2015.

50. Kang, $\mathrm{H}$. The Prevention and Handling of the Missing Data. Korean Journal of Anesthesiology. 2013, 64 (5), 402-406.

51. Sleep, S., Laurenzi, I. J., Bergerson, J. A., MacLean, H. L. Evaluation of Variability in Greenhouse Gas Intensity of Canadian Oil Sands Surface Mining and Upgrading Operations. Environmental Science \& Technology. 2018, 52 (20), 11941 - 11951.

52. Bergerson, J. A., Kofoworola, O., Charpentier, A. D., Sleep, S., MacLean, H. L. Life Cycle Greenhouse Gas Emissions of Current Oil Sands Technologies: Surface Mining and In Situ Applications. Environmental Science \& Technology. 2012, 46, 7865-7874. 
53. PRELIM v1.3: the Petroleum Refinery Life Cycle Inventory Model. https://www.ucalgary.ca/lcaost/prelim (accessed July 23, 2019).

54. Rosenfeld, J., Pont, J., Law, K., Hirshfeld, D., Kolb, J. Comparison of North American and Imported Crude Oil Lifecycle GHG Emissions. TIAX LLC, MathPro Inc. for Alberta Energy Research Institute. Calgary, Alberta. July 6, 2009.

55. GHGenius Model 4.03: Model Background and Structure. Prepared by $(\mathrm{S} \& T)^{2}$ Consultants Inc. for Natural Resources Canada. Ottawa, Ontario. June 15, 2013.

56. PRELIM v1.2.1: the Petroleum Refinery Life Cycle Inventory Model. https://www.ucalgary.ca/lcaost/prelim (accessed November 26, 2018). 